\title{
Libertad de expresión y el mito de Internet como una experiencia no intermediada
}

\author{
Free Speech and the Myth of the Internet as an \\ Unintermediated Experience
}

\author{
CHRISTOPHER S. YOO \\ Center for Technology, Innovation \& Competition, University of Pennsylvania \\ Law School
}

RESUMEN En los últimos años, un creciente número de académicos han manifestado su preocupación sobre decisiones tomadas por los intermediarios en Internet -incluyendo a los proveedores de acceso a Internet, motores de búsqueda, sitios de redes sociales y teléfonos inteligentesque están inhibiendo la libertad de expresión y han solicitado restricciones a su capacidad de priorizar o excluir contenidos. Estas alertas hacen caso omiso del hecho de que cuando se trata de comunicación de masas, la intermediación ayuda a los usuarios finales a protegerse de contenidos no deseados y les permite discernir entre una avalancha de contenido sí deseado que se hace cada día más grande. La intermediación también ayuda a resolver una serie de problemas económicos clásicos asociados a Internet. En resumen, la intermediación de contenido de medios de masas es inevitable y a menudo beneficiosa. Estas solicitudes de restringir la intermediación también han pasado por alto la larga tradición reflejada en jurisprudencia de la Corte Suprema de Estados Unidos sobre la Primera Enmienda respecto a otras formas de comunicación electrónica, que reconoce el ejercicio de la discreción editorial del intermediario como promoción de los valores de la libertad de expresión. El debate 
también hace caso omiso de la historia desfavorable/dudosa de los esfuerzos del pasado para regular el alcance de la discreción editorial de los intermediarios electrónicos, que se caracterizaron por su incapacidad de desarrollar estándares coherentes, provocando un efecto paralizante en el discurso polémico y la manipulación de las normas con fines políticos.

PALABRAS CLAVE Internet, política de banda ancha, intermediarios, neutralidad en la red, privacidad, seguridad.

ABSTRACT In recent years, a growing number of commentators have raised concerns that the decisions made by Internet intermediaries -including last-mile network providers, search engines, social networking sites, and smartphones- are inhibiting free speech and have called for restrictions on their ability to prioritize or exclude content. Such calls ignore the fact that when mass communications are involved, intermediation helps end users to protect themselves from unwanted content and allows them to sift through the avalanche of desired content that grows ever larger every day. Intermediation also helps solve a number of classic economic problems associated with the Internet. In short, intermediation of mass media content is inevitable and often beneficial. Calls to restrict intermediation have also largely overlooked the longstanding tradition reflected in the Supreme Court's First Amendment jurisprudence with respect to other forms of electronic communication recognizing how intermediaries' exercises of editorial discretion promote free speech values. The debate also ignores the inauspicious/dubious history of past efforts to regulate the scope of electronic intermediaries' editorial discretion, which were characterized by the inability to develop coherent standards, a chilling effect on controversial speech, and manipulation of the rules for political purposes.

KEYWORDS Internet, broadband policy, intermediation, net neutrality, privacy, security.

\section{INTRODUCCIÓN}

Cuando Internet surgió muchas personas alabaron su potencial de permitir que individuos se dirigieran directamente al público sin tener que depender de los guardianes que por mucho tiempo habían decidido el 
contenido de los medios de comunicación. ${ }^{1}$ El lenguaje de la Corte Suprema, en su contundente sentencia del caso Reno $v$. ACLU, ${ }^{2}$ hizo eco de un pensamiento similar cuando alabó cómo Internet le permite a «cualquier persona con una línea telefónica» convertirse en un "panfletista» o un «pregonero con una voz que resuena más lejos de lo que hubiera logrado desde cualquier tribuna». ${ }^{3}$ Otros académicos fueron menos optimistas, argumentando que el establecimiento de regulación podría ser necesario para garantizar que Internet represente una experiencia no intermediada en que los oradores pudieran comunicarse directamente con las audiencias (Berman y Weitzner, I995: 1636-37).

En años recientes, las preocupaciones por el rol de los intermediarios de Internet siguen creciendo. El debate se enfocó inicialmente en la capacidad de los proveedores de acceso a Internet (en adelante, «ISP», por sus siglas en inglés) para privilegiar ciertos contenidos o aplicaciones, ya sea dándoles distintos niveles de prioridad o cobrándoles distintas cantidades de dinero. ${ }^{4}$ Este asunto alcanzó su punto culminante en 2009 cuando la Federal Communications Comission (en adelante, la «FCC») sancionó a la empresa Comcast por ralentizar el tráfico asociado a una única aplicación, sanción que luego fue revocada judicialmente. ${ }^{5}$ Algunos también han advertido sobre el potencial de los motores de búsqueda para influir en el ambiente de libre expresión al sesgar los resultados de búsquedas (cf. Bracha y Pasquale, 2008: II6I-79; Chandler, 2007; Elkin-Koren, 200I). Otros han llamado a exigir acceso abierto a tecnologías de redes sociales y de intercambio de archivos, como YouTube, BitTorrent, Facebook y MySpace (cf. Balkin, 2008: 936-37; Tushnet, 2008: 996-I002). Recientemente, ha surgido una polémica respecto del acceso a ciertas tecnologías clave en dispositivos, como quedó demostrado en la investigación iniciada por la FCC respecto de la decisión de

I. El enunciado clásico es de Volokh (I995: I834-38). Para otras observaciones similares, véase, por ejemplo, Redish y Kaludis (I999: II30-3I), Sullivan (I998: I670-73) y Noam (1996).

2. Reno v. ACLU (1997), 52 I U.S. 844 .

3. Reno v. ACLU, pág. 870.

4. El debate inicial se enfocó en el acceso de múltiples proveedores de servicios de Internet a sistemas de cable módem (véase Lemley y Lessig, 200I). Más recientemente, el debate se ha enmarcado en los términos de la neutralidad de la red (Lessig, 2006; Wu, 2003).

5. Comcast Corp. v. FCC (2010), ०8-I29I (D.C. Cir.). 
Apple de no portar ciertas aplicaciones de voz desarrolladas por Google (Abelson, 2009). E incluso otros comentaristas se han centrado no en la capacidad de los intermediarios para amoldar la libre expresión en Internet a sus propios puntos de vista, sino en la capacidad del gobierno para regular a los intermediarios como una forma indirecta de imponer sus propias preferencias expresivas (Birnhack y Elkin-Koren, 2003; Kreimer, 2006; Wu, 2009). Reportajes en periódicos llaman la atención constantemente sobre la forma en que algunos intermediarios, como Comcast, Google, Facebook y Apple, seleccionan y priorizan contenidos y aplicaciones (Hansell, 2008; Nocera, 2008; Rosen, 2008; Wortham, 2009).

Debe destacarse que muchos de estos alegatos revelan una profunda inconsistencia interna. A veces el proveedor de acceso es acusado de utilizar su poder de mercado de forma tal que daña a los desdichados proveedores de dispositivos y aplicaciones. En otros casos, es el fabricante de dispositivos el acusado de abusar de su posición dominante, mientras que en otros casos se acusa al proveedor de aplicaciones (especialmente de software de redes sociales y motores de búsqueda). En pocas palabras, estas acusaciones no pueden ser propuestas simultáneamente de forma coherente. De hecho, si más de uno de los niveles de esta cadena de distribución es dominado por un solo actor, el concepto económico de la «doble marginalización» sugiere que los consumidores estarían mejor si ambos fueron controlados por una sola entidad (Yoo, 2002: 192-93, 260-6I).

Aunque la discusión se enfocó inicialmente en el impacto de dicha intermediación desde un punto de vista económico, como en la competencia y la innovación, recientemente los expertos han fundamentado sus argumentos en contra de la intermediación en la Primera Enmienda de la Constitución de los Estados Unidos, ${ }^{6}$ si bien no de forma literal. Bajo la ley vigente, la Primera Enmienda sólo restringe los actos de entes públicos y no de individuos privados (Nunziato, 2009: 35-39; Balkin, 2009: 429-30). En consecuencia, bajo la interpretación convencional de la Primera Enmienda, los intentos gubernamentales de restringir la libertad de expresión de los individuos privados serían constitucionalmente

6. Véase Nunziato (2009), Balkin (2009: 428-33), Bracha y Pasquale (2008: II 88I20I), Herman (2006: II2-I9), May (2007: 202-IO), Travis (2007: I 564-8I) y Yemini (2008). 
problemáticos. Desde hace tiempo los expertos han insistido en teorías que transformarían a la Primera Enmienda, de una limitación negativa sobre los actos de gobierno a una obligación positiva de que el gobierno provea los medios para un ejercicio efectivo del derecho a la libertad de expresión. ${ }^{7}$ Aunque la Corte Suprema contempló por un momento la posibilidad de que los emisores de señales de televisión o radio y las empresas que prestan servicios públicos fueran considerados como actores públicos para propósitos de la Primera Enmienda, ${ }^{8}$ las decisiones posteriores de la Corte derechamente desecharon esta posibilidad. ${ }^{9}$ A pesar de los mejores esfuerzos de algunos partidarios de expandir el alcance de la Primera Enmienda, ella permanece como un límite a los actos de gobierno que no alcanza a los actos de privados. Por lo tanto, invocar la Primera Enmienda para exigir intervención gubernamental para remediar los actos de privados invertiría su aplicación.

En cambio, estos comentaristas deben ser más bien considerados como proponentes de políticas respaldadas por los valores de la libertad

7. Para el enunciado original de esta postura, véase Barron (1967). Véase también Fiss (I996: I 5-I 8) y Sunstein (I995: 44-45). Para propuestas de aplicar este razonamiento a Internet, véase Lessig (I999: I64-68), Nunziato (2009: 4 I-69) y Herman (2006: I I 2).

8. Pub. Utils. Comm'n v. Pollak (1952), 343 U.S. 45 I, pág. 462, determinó que el hecho de que un tranvía operado bajo la supervisión de una Comisión de Servicios Públicos constituía acción estatal suficiente para someter la decisión del tranvía de reproducir programas de radio al escrutinio de la Primera Enmienda. En una decisión posterior, la Corte se dividió 4-2 sobre si los emisores eran entes públicos, concluyendo que no lo eran (CBS, Inc. v. Democratic Nat'l Comm. [I973], 4 I 2 U.S. 94, págs. I I 5-2 I).

9. Jackson v. Metro. Edison Co. (I974), 4I9 U.S. 345, págs. 352-53, sostiene que la prestación de servicios públicos no es suficiente para constituir acción estatal. Véase en general Yoo (2003: 334). Para sentencias que sostienen que los ISP no son entes públicos, véase Green v. Am. Online (AOL), 3 I 8 F.3d 465, 472 (3d Cir. 2003); Howard v. Am. Online, Inc., 208 F.3d 74I, 754 (9th Cir. 2000); Noah v. AOL Time Warner, Inc., 26I F. Supp. 2 d 532, 546 (E.D. Va. 2003); Cyber Promotions, Inc. v. Am. Online, Inc., 948 F. Supp. 436, 443-44 (E.D. Pa. I996). Para fallos que sostienen que los motores de búsqueda no son entes públicos, véase Langdon v. Google, Inc., 474 F. Supp. 2d 622, 63 I32 (D. Del. 2007). Para una sentencia que sostiene que los grupos de e-mails de Yahoo! no son entes públicos, véase Murawski v. Pataki, 5 I4 F. Supp. 2d 577, 588 (S.D.N.Y. 2007). Otro tribunal señala: «Debido a que estos proveedores de Internet no son entes públicos, ellos son libres de imponer restricciones basadas en el acceso al contenido de Internet sin involucrar a la Primera Enmienda» (Sanger v. Reno, 966 F. Supp. I 5 I, I63 [E.D.N.Y. I997]). 
de expresión consagrados en la jurisprudencia de la Corte Suprema sobre la Primera Enmienda.

En términos generales, quienes proponen regular a los intermediarios argumentan que los intereses discursivos de aquellos que buscan transmitir sus contenidos y aplicaciones a través de la red son los que importan. ${ }^{10}$

Tal enfoque hubiera sido apropiado para comunicaciones de persona a persona, como por ejemplo la telefonía y las aplicaciones dominantes durante la Internet temprana: el correo electrónico o la transferencia de archivos. En esos casos, los proponentes argumentan que los únicos intereses de libre expresión relevantes son los de los usuarios finales, y no los de los proveedores de acceso a la red. ${ }^{11}$ Como veremos, el alcance de los derechos de la Primera Enmienda que benefician a las empresas que prestan servicios públicos es mucho más incierto de lo que se reconoce generalmente. Aún más relevante para nuestros fines, la Internet moderna ya no es simplemente un medio de comunicación persona a persona. Ahora es quizás la plataforma dominante para comunicaciones masivas. La expresión en medios de comunicación masiva implica un rango más amplio de valores de libre expresión que incluyen los intereses tanto de las audiencias y los intermediarios, como de los comunicadores.

Para determinar cómo equilibrar este conjunto más complejo de valores podemos guiarnos por un cuerpo de conocimientos que no ha sido suficientemente explorado por la literatura: las decisiones de la Corte Suprema que aplican la Primera Enmienda a los medios de comunicación masiva, especialmente aquéllas que se refieren a los medios de comunicación electrónicos históricamente líderes (la radiodifusión y la televisión

I0. Véase Bracha y Pasquale (2008: I 200); Herman (2006: I I3); Travis (2007: I 577); Carta ex parte de Timothy Wu, Profesor Asociado Facultad de Derecho, Universidad de Virginia, y Lawrence Lessig, Profesor de Derecho, Facultad de Derecho, Universidad de Stanford, a la FCC sobre el documento «High-Speed Access to the Internet over Cable and Other Facilities, Declaratory Ruling and Notice of Proposed Rulemaking», I7 F.C.C.R. 4798 (2002). Disponible en <http://fjallfoss.fcc.gov/ecfs/document/ view? id=65I4683884>.

I I. Para leer comentarios que emplean esta lógica para concluir que la telefonía no involucra a la Primera Enmienda, véase Zuckman y otros (I999: I 85-89), Baker (I976) y Brenner (I99I: I 25). 
por cable). Estos precedentes han reconocido ampliamente que la discreción editorial que ejercen los intermediarios promueve importantes valores de libre expresión al ayudar a proteger al público de contenidos indeseados y al ayudar a que el público pueda identificar y acceder a contenidos deseados. Respecto a Internet, los intermediarios ayudan a los usuarios a protegerse del spam, la pornografía, los virus y otras formas de malware, ayudándolos también a poder navegar a través de la siempre creciente avalancha de contenido deseado que diariamente aparece en Internet (Goldman, 2006: I95-96; Grimmelmann, 2008-2009: 94I). En consecuencia, los tribunales han reconocido que la discreción editorial ejercida por los motores de búsqueda y los proveedores de acceso es importante para la libertad de expresión. ${ }^{12}$ De hecho, a menos que uno espere que todos los usuarios finales se arrastren diariamente por la totalidad de la web, incluso los críticos a la intermediación reconocen que ésta puede ser beneficiosa y podría ser inevitable. ${ }^{13}$

En resumen, la imagen de Internet como una experiencia sin intermediarios, en que los comunicadores le hablan directamente a las audiencias sin pasar por algún guardián, es más mito que realidad. La pregunta de fondo no es si algún actor, sino más bien qué actor, servirá como intermediario. La jurisprudencia sobre la Primera Enmienda de la Corte Suprema enfatiza que importantes consideraciones sobre la libertad de expresión afectan a ambos lados del debate sobre la intermediación. ${ }^{14}$ Es más, al decidir cómo debe fijarse un equilibrio, los casos indican que las consideraciones sobre libertad de expresión favorecen el preservar la discreción editorial de los intermediarios a menos que las tecnologías relevantes caigan dentro del angosto rango de excepciones, todas las cuales la Corte Suprema las ha considerado inaplicables para Internet. En efecto, los precedentes de la Corte Suprema reconocen la importancia de la discreción editorial incluso cuando los intermediarios solamente sirven como mero conducto para el discurso de terceros. Aún más, la Corte

I2. Véase Langdon, 474 F. Supp. 2d, págs. 629-30, sobre motor de búsqueda; Comcast Cablevision of Broward County, Inc. v. Broward County, I 24 F. Supp. 2 d 685, págs. 693-94 sobre proveedores de cable módem.

I3. Véase Goodman (2007: I220-23); Kreimer (2006: I7); Schejter y Yemini (2007: I67); Netanel (2008: 968-69); Yemeni (2008: 17-20).

I4. Véase Turner Broad. Sys., Inc. v. FCC (I997), 520 U.S. I80, págs. 226-27. 
Suprema ha sostenido durante mucho tiempo que un intermediario puede ejercer un poder monopólico y que el riesgo de que en ese ejercicio el intermediario actúe como un censor privado no justifica regular la discreción editorial. Ello sustituiría una toma de decisiones privada por una toma de decisiones pública, y si bien los precedentes de la Corte Suprema y nuestras tradiciones sobre libertad de expresión son agnósticas respecto a qué actor privado debería servir de intermediario, éstas son muy claras en declarar que no debe ser el gobierno; y al optar entre la censura por un actor privado y uno gubernamental, la elección siempre debe favorecer al privado por sobre el público. ${ }^{15}$

La estructura de este artículo es la siguiente: la parte I se refiere a la inevitabilidad de la intermediación, en lo que dice relación tanto con la protección de los usuarios finales respecto a contenido indeseado, como con ayudarlos a identificar y acceder a contenido deseado. También analiza la forma en que los intermediarios pueden ser esenciales para resolver ciertos problemas transaccionales que pueden impedir que los usuarios finales accedan al contenido que desean. La parte II analiza los precedentes judiciales reconociendo los importantes valores sobre libertad de expresión promovidos por el ejercicio de discreción editorial de los intermediarios, incluyendo las decisiones de la Corte Suprema respecto a periódicos, organismos de radiodifusión y televisión por cable. También examina las sentencias de los tribunales inferiores sobre dial-a-porn ${ }^{16}$ y sobre los derechos de Primera Enmienda de las empresas telefónicas al ofrecer programación de video, las que exploran cómo la discreción editorial puede promover la libertad de expresión incluso cuando se trata de empresas que prestan servicios públicos, como las compañías de teléfono. La parte III analiza la poco auspiciosa historia de intentos por regular la discreción editorial ejercida por intermediarios electrónicos. En conjunto, estos puntos de vista enfatizan de qué modo el ejercicio de la discreción editorial de los intermediarios puede promover más que impedir el ejercicio de la libertad de expresión.

I 5. Véase CBS, Inc. v. Democratic Nat’l Comm. (I973), 4I 2 U.S. 94, págs. I24-26; Krattenmaker y Powe, Jr. (I994: 327).

I6. Nota de los traductores. Dial-a-porn es un servicio comercial de conversaciones telefónicas de contenido sexual o erótico, ampliamente utilizado en Estados Unidos. 


\section{LOS BENEFICIOS E INEVITABILIDAD DE LA INTERMEDIACIÓN}

Cuando Internet surgió originalmente, servía primariamente como un medio de comunicación entre personas que usaban el correo electrónico y la transferencia de archivos. Aunque algunas formas de comunicación masiva existían en la temprana Internet (como los grupos de noticias y los bulletin boards electrónicos), éstas representaban una proporción relativamente pequeña del tráfico total de Internet.

Durante la década del noventa, la naturaleza de Internet sufrió un cambio fundamental. La privatización de la red troncal de Internet y la concomitante eliminación de las restricciones sobre el comercio en la red gatillaron una explosión de contenidos de medios masivos en la web.

El surgimiento de Internet como un importante medio de comunicaciones masivas causó un cambio igualmente relevante en la importancia de los intermediarios de Internet, tanto respecto de su colaboración para que los usuarios finales filtraran contenido malo, como su colaboración para que los usuarios finales identificaran y accedieran a contenido bueno. Adicionalmente, la literatura sobre la economía de la intermediación subrayaba cómo los intermediarios pueden jugar roles claves en ayudar los usuarios finales a obtener los contenidos que desean. En conjunto, estos puntos de vista demostraron que la intermediación no debe ser considerada como un mal necesario, como algunos comentaristas sugieren. Al contrario, la intermediación puede jugar un rol clave en ayudar a los usuarios finales a acceder a los contenidos y aplicaciones que deseen.

\section{A. CONTROLANDO CONTENIDOS NO DESEADOS}

El surgimiento de Internet como una importante fuente de contenidos de medios masivos ha llevado a los usuarios finales a buscar ayuda de los intermediarios para protegerse de contenidos no deseados (como spam, malware y pornografía) y ataques no deseados (como virus, troyanos y otras formas de malware). Hacia el fin de la década de los noventa, dicha intermediación era usualmente ejecutada por software de firewall y filtros instalados en los computadores a través de los cuales los usuarios finales se conectaban a Internet. ${ }^{17}$ Muchos comentaristas han alabado

I7. Véase Reno v. ACLU, pág. 877. También Ashcroft v. ACLU (2004), 542 U.S. 
este filtro en los extremos como la mejor forma de asegurarse que el control sobre los contenidos se mantenga en las manos de los usuarios finales. ${ }^{18}$ El concentrar la inteligencia en las aplicaciones que operan en los extremos de la red era también consistente con el argumento de extremo-a-extremo y los principios de capas que muchos comentaristas consideran como una parte esencial de la arquitectura de Internet. ${ }^{19}$

Otros tuvieron una visión menos optimista de filtrar en los extremos. Algunos notaron que el uso de tecnologías de filtrado inadvertidamente impediría el acceso por los usuarios finales a contenido benigno y le daría a las empresas de software que crean y actualizan software de filtrado, un control como guardianes sobre los contenidos que los usuarios finales reciben. ${ }^{20}$ Otros observaron que un despliegue masivo de tecnologías de filtrado por los usuarios finales facilitaría el control gubernamental de los contenidos (Goldsmith, I998: I227; Wu, I997: 654; Zittrain, 2003: 688). Incluso algunos advirtieron que un despliegue masivo de filtros en los extremos tendría el efecto secundario de sesgar la innovación (Lessig, 200I: I72-74; Zittrain, 2008: 36-6I, IOI-26).

Con el paso del tiempo, muchas funciones de firewall y filtros han empezado a migrar desde los extremos de la red hacia la red misma. Muchos proveedores de acceso a Internet incluyen protección antivirus y firewalls como parte del software necesario para acceder a sus sistemas. Los proveedores de acceso también han empezado a construir filtros de spam y malware en el núcleo de sus redes.

El traslado de estas funciones de filtrado desde el usuario final hacia la red misma se debe en parte al cambio en la naturaleza del usuario de In-

656, pág. 667 , que brinda una reafirmación más reciente de la visión de filtrar en los extremos.

I 8. Véase Berman y Weitzner (I995: I632-35); Developments in the Law. The Law of Cyberspace, II 2 HARV. L. REV. I 574, I64I (I999); PICS, Censorship, \& Intellectual Freedom FAQ (Paul Resnick, ed.), <http://www.w3.org/PICS/PICS-FAQ-980 26.html>.

I9. En cuanto a la consistencia de filtrar en los extremos con el argumento de extremo a extremo, véase Lessig (I998: 660). En cuanto a la consistencia de filtrar en los extremos con una arquitectura de capas, véase Solum y Chung (2004: 892-94).

20. Véase Balkin (I996: I I 52-53); Lessig (I998: 652-70); Lessig y Resnick (I999: 424-269); Nachbar (2000); Wagner (I999); Weinberg (I997); EPIC, Faulty filters: how content filters block access to kid-friendly information on the internet (I997), <http:// epic.org/reports/filter_report.html>. 
ternet. En sus inicios, Internet servía primariamente como un medio para conectar a técnicos universitarios que compartían un conjunto común de valores y tenían un grado relativamente alto de conocimientos técnicos y de soporte institucional. Desde entonces, Internet se ha convertido en una tecnología de masas. El cambio de la base de usuarios dominada por inexpertos sin ningún tipo de soporte técnico ha aumentado la justificación de transferir más funciones al centro mismo de la red (Yoo; 2004: 35; véase también Blumenthal y Clark, 200I: 74).

Otra consideración son los costos. El requerir que todos los filtros operen en los extremos implica que la red debe soportar el costo total de despachar el contenido incluso si no es deseado. Filtrar el contenido no deseado lo más pronto posible minimiza el consumo de recursos de la red. Adicionalmente, un filtro que opera en el núcleo de la red puede aprovechar la información acumulada que no está disponible para los usuarios individuales (Clark y Blumenthal, 2007: 24). Además, los filtros a nivel de usuario final son más caros de implementar y mantener, debido a que su implementación requiere de miles de instalaciones y una serie continua de actualizaciones de seguridad.

Finalmente, el predominio de troyanos, spyware, key loggers y otras formas de código hostil han provocado que los usuarios finales desconfíen cada vez más de sus propios computadores (Clark y Blumenthal, 2007: I6). Si bien una solución es intentar recuperar el control del computador personal haciéndolo más seguro, una solución alternativa es reducir su vulnerabilidad externalizando las funciones de seguridad en servidores localizados en el núcleo de la red (Clark y Blumenthal, 2007: I6-7).

Los tecnólogos líderes en general reconocen que el actual diseño de Internet no está bien adaptado para enfrentar problemas de seguridad (Peha, 2007: 659). Como informa un artículo del New York Times, la creciente necesidad de seguridad de redes ha llevado a muchos tecnólogos a sugerir que Internet debe rediseñarse de forma tal que la seguridad en sus capas y la verificación de identidad sean características más centrales de la red (Markoff, 2009). Por ejemplo, la National Science Foundation está patrocinando las iniciativas Global Environment for Network Innovations y Future Internet Design para crear una nueva arquitectura que 
realce la seguridad como una parte más integral de la red. ${ }^{21} \mathrm{El}$ proyecto ıо०xı Clean Slate y el Northwestern's International Center for Advanced Internet Research están persiguiendo objetivos similares. ${ }^{22}$

Mi punto aquí no es resolver si dichas funciones son mejor resueltas por computadores operando en los extremos de la red o dentro de la red misma. Que la mejor solución sea finalmente una intermediación en la red, o por los usuarios finales, es una pregunta que no puede ser respondida a priori. Consideraciones como los costos de implementación y las economías de escala varían con el paso del tiempo, lo que incrementa la posibilidad de que el lugar óptimo para remover contenidos indeseados dependerá del contexto. Adicionalmente, el advenimiento de nuevas tecnologías, como el fingerprinting de audio y video, puede causar que el lugar de más bajo costo se traslade progresivamente hacia el centro de la red (Hughes, 2009: 4I, 45-47, 62). Aún más, Internet está compuesta de un rango crecientemente diverso de tecnologías de redes, y la intensidad de la demanda varía ampliamente en distintas partes de la red. La decisión entre dos perspectivas depende también de la heterogeneidad de lo que los usuarios finales consideren como contenido indeseado. Las soluciones basadas en la red parecen ser más efectivas respecto de contenido como spam, del cual a todos los usuarios les gustaría estar protegidos. Al mismo tiempo, las soluciones basadas en la red pueden permitir menos personalización por parte de los usuarios. En la medida que la proporción de usuarios finales que quieran acceder a cierta clase de contenidos aumente, el equilibrio tiende a favorecer una solución basada en ellos por sobre una basada en la red. En efecto, si lo que desean los usuarios finales es lo suficientemente heterogéneo, una solución no uniforme puede ser el resultado, y cada solución particular variará dependiendo del proveedor.

Mi punto es más limitado. Como lo demuestra el hecho de que aún existe controversia respecto al control por guardianes, a pesar de que los

2I. Global Environment for Network Innovations (<http://www.geni.net> y National Science Foundation, NeTS FIND Initiative (<http://www.nets-find.net>).

22. Véase la misión de Iooxıoo Clean Slate Project disponible en <http://IooxIoonetwork.org/mission.html>. Northwestern University Information Technology, iCAIR: International Center for Advanced Internet Research, en <http://www. icair.org>. 
filtros están ubicados en los usuarios finales, los intermediarios existirán sin importar si la tecnología de filtros está en los extremos o en el núcleo de la red. De hecho, la migración de las tecnologías de filtrado hacia el núcleo de la red sencillamente representa un cambio en el lugar de intermediación, no el advenimiento de intermediación donde antes no la había.

\section{B. IDENTIFICANDO EL CONTENIDO BENIGNO}

Igualmente relevante, los intermediarios ayudan a los usuarios finales a localizar y obtener acceso al contenido que ellos consideran deseable. La privatización de Internet y el desarrollo de la World Wide Web han transformado a Internet en una vasta y vibrante fuente de contenidos cuya magnitud se expande diariamente. El despliegue a gran escala de aplicaciones relacionadas con la Web 2.0, que convierte a los usuarios finales en importantes generadores de contenidos como también en consumidores de éstos, debería incrementar dramáticamente tanto la cantidad de contenidos disponibles como la diversidad en su calidad.

Los usuarios finales son incapaces por sí mismos de navegar a través de esta avalancha de contenidos nuevos y ya existentes que hay en Internet. Dependen, en cambio, para poder ayudarlos a identificar y recuperar contenido previamente desconocido, pero que podría serles de interés, de una gran variedad de agregadores de contenido, como boletines de correo electrónico, bloggers y motores de búsqueda. No hay dos intermediarios que sean exactamente iguales. En efecto, el contenido elegido y la forma en que es presentado representan voces editoriales distintivas que constituyen la fuente de valor primaria que ofrecen a los usuarios finales.

Consideremos el surgimiento de Google como el principal motor de búsqueda. Google fue capaz de desplazar a AltaVista y una gama de otros motores de búsqueda ya establecidos porque empleó un algoritmo que era más eficiente en identificar el contenido que los usuarios finales consideraban interesante (Lastowka, 2008: I334-37). Desde luego, el protocolo de rankings de Google devuelve resultados en un orden distinto del de otros motores de búsqueda, y este hecho inevitablemente privilegia a ciertos sitios web sobre otros. Aunque dicha diferenciación inevitablemente molesta a aquellos sitios que el protocolo de Google 
desfavorece, estas diferencias son esenciales para el éxito de este tipo de intermediario. Son, por lo tanto, difíciles de entender las críticas que dicen que los resultados devueltos por los motores de búsqueda son «sesgados» (Bracha y Pasquale, 2008: II67-7I; Chandler, 2007: I I05; Elkin-Koren, 200I: I 87-9I), cuando precisamente este sesgo es la esencia misma del negocio (Goldman, 2006: I95-98; Goodman, 2008: 9I0-I2). Aún más, una adhesión obligada a una estrategia específica de búsqueda amenaza con limitar los beneficios que pueden proveer y, en la medida en que se aplique a todos los motores de búsqueda y no sólo a Google, disuadiría el ingreso al mercado, al limitar los espacios en los que un nuevo motor de búsqueda podría competir (Grimmelmann, 2007).

Además, de competir con sus competidores directos, los distintos actores de las industrias de Internet lo están haciendo con los proveedores de servicios complementarios, para llegar a ser el intermediario preeminente. Un ejemplo de ello es el redireccionamiento por errores en la web, un servicio nuevo que tiene el potencial de otorgar beneficios reales a los usuarios finales. Hasta hace poco, cuando la mayoría de los usuarios escribía mal la dirección de un sitio web en el navegador, este devolvía una pantalla indicando un «Error 404. Archivo no encontrado». Los navegadores progresivamente han empezado a transmitir la dirección errónea a un motor de búsqueda, el que a su vez le sugiere al usuario las alternativas más probables del resultado buscado, otorgándole al usuario acceso a la dirección correcta con un solo clic. Una contienda ha surgido entre los navegadores, los motores de búsqueda y los proveedores de acceso para resolver quien determinará la herramienta de búsqueda que llevará a cabo esta función.

Si bien algunos analistas pueden tener fuertes convicciones respecto a la clase de proveedor que puede realizar ciertas funciones específicas, y cuales no (cf. Felten, 2007), en última instancia soy agnóstico respecto a cuál actor debería intermediar este tipo de operación. ${ }^{23}$ Para efectos de este artículo, mi opinión más limitada es la inevitabilidad de que alguna empresa intermedie el acceso de los usuarios finales al contenido. La

23. De hecho, los intentos de los actores de la industria por expandirse hacia mercados adyacentes puede representar la mejor forma disponible de rivalidad en Internet. Véase Yoo (2002: 282-85). 
competencia emergente entre distintos actores en la red enfatiza que la elección no es entre intermediación y no intermediación, sino en determinar cuál empresa funcionará como intermediaria. El impedir que una clase específica de actor opere como intermediario simplemente trasladará esas funciones hacia otro actor.

\section{LOS POTENCIALES BENEFICIOS DE LA INTERMEDIACIÓN}

Además de ayudar a los usuarios finales a filtrar contenidos indeseados y localizar y acceder a contenidos deseados, los intermediarios pueden desarrollar varios roles económicamente beneficiosos. A pesar de que Internet es usualmente descrita como si fuera un sistema unificado, es de hecho una combinación de sistemas autónomos que interactúan a través de una red de acuerdos de interconexión. Cada sistema autónomo toma sus propias decisiones independientes respecto de las otras redes con las cuales se interconectará y determina las condiciones de interconexión con dichas redes a través de negociaciones en términos igualitarios.

La consecuencia es que contenidos similares pueden tomar caminos radicalmente distintos a través de la red, dependiendo de los acuerdos específicos de interconexión que el proveedor de red haya negociado. Adicionalmente, el precio que este tráfico pagará variará dependiendo de los términos específicos negociados en los acuerdos de interconexión (Yoo, 2010: 80, 85-90, 95-99). Y lo que es más importante, el depender de negociaciones en términos igualitarios hace inevitable que las condiciones de interconexión dependan en gran parte del poder negociador que posean los diversos proveedores de redes. En efecto, el ejercer poder negociador a corto plazo juega un papel importante en la reasignación de recursos y en el otorgamiento de incentivos para que los mercados con desequilibrios a largo plazo se reequilibren. En términos generales, mientras sea posible poder acceder en términos competitivos a un segmento particular de una industria, toda utilidad supracompetitiva debería probar ser de corta duración. Las intervenciones regulatorias que inhiben la obtención de estas utilidades en el corto plazo tendrían en consecuencia el desafortunado efecto de impedir que el mercado reasigne recursos a su mayor y mejor uso (Yoo, 2005: 9-10, 29-33, 48-53).

Dicho lo anterior, la literatura económica ha identificado las condiciones que causan que los resultados de estas negociaciones se desvíen 
del óptimo a largo plazo. Como se discutirá en mayor detalle en las próximas secciones, el número de actores, las asimetrías de información y la capacidad de actuar oportunistamente pueden provocar que las partes no lleguen a acuerdos incluso cuando ello significase el mejor interés mutuo. La literatura también reconoce que los intermediarios pueden ayudar a resolver estas fallas de mercado. ${ }^{24}$

\section{NEGOCIACIONES MULTILATERALES}

Una de las formas clásicas en que una negociación puede fallar es cuando implica un gran número de partes. Como mínimo, la sola fricción que implica el reunir y negociar con varias partes incrementa los costos de transacción de una negociación multilateral (Olson, Jr., I965: 4648). Adicionalmente, las partes en una negociación multilateral tienen el incentivo de obtener beneficios sin pagar por ellos o de ocultar información para capturar una mayor proporción del excedente disponible (Buchanan y Tullock, I962: I05-09).

Una solución clásica a los problemas asociados a una negociación multilateral es que el Estado actúe como intermediario imponiendo una regla de responsabilidad, que impide los comportamientos oportunistas al establecer un precio al que debe llegarse a acuerdo (Calabresi y Melamed, I972: I 106-07). Trabajos posteriores han demostrado que no es necesario que el intermediario sea el Estado. «Contracting into Liability Rules», el texto clásico de Robert Merges, contiene ricos e importantes ejemplos de cómo las partes crean intermediarios privados para resolver problemas de las negociaciones multilaterales (Merges, 1996). No obstante, la intermediación privada no debe ser considerada como una panacea; de hecho, algunos expertos han investigado las circunstancias en que esas soluciones colectivas creadas privadamente probablemente fracasarán. ${ }^{25}$ Sin embargo, la posibilidad de que fracasen no justifica rechazar de entrada la intermediación privada. Sobre todo cuando se combina con la amenaza que una intermediación gubernamental pueda constituir para la libertad de expresión, la que discutiremos más adelan-

24. Para una descripción no técnica de los roles económicos desempeñados por los intermediarios, véase Spulber (I996: I35). Véase también Cotter (2006: 69-74).

25. Para los análisis clásicos, véase en general Libecap (I989) y Ostrom (I990). 
te, los beneficios de una intermediación privada sugieren que debería ser incentivada siempre que sea posible.

\section{ASIMETRÍAS DE INFORMACIÓN}

Los intermediarios también pueden resolver otro problema clásico que puede impedir el alcanzar soluciones eficientes por medio de una negociación: las asimetrías de información. ${ }^{26}$ Éstas ocurren cuando una o ambas partes tienen información privada que la contraparte no puede verificar (Williamson, I975: 3I-35). Dos partes que negocian deben realizar dos funciones distintas. En primer lugar, deben determinar si existen ganancias derivadas de negociar y, de ser así, la mejor forma para maximizarlas. En este aspecto del proceso negociador, los intereses de las partes están alineados, pues ambas se benefician al asegurarse que el excedente que se repartirán sea lo más grande posible. En segundo lugar, deben determinar cómo repartir el excedente derivado de la negociación. En este aspecto del proceso negociador, el aspecto suma cero de la repartición del excedente hace que los intereses de las partes difieran bastante.

Si ambas partes tuvieran información completa, las partes resolverían ambas funciones con relativa facilidad. El conocimiento perfecto de los precios de reserva de la contraparte le permitiría a ambas partes poder determinar si existen ganancias derivadas del intercambio. Adicionalmente, el conocimiento perfecto del poder negociador de la contraparte sería un indicativo de cómo repartir el excedente. Esta situación es radicalmente distinta cuando una o ambas partes tienen información privada. En ese caso, cada parte debe transmitirle a la otra algo de esa información para que ambas puedan determinar si existe un acuerdo mutualmente beneficioso y la forma en que deben dividirse los beneficios derivados del acuerdo (Brown y Ayres, 1994: 332 ).

El problema es que el revelar la información privada necesaria para determinar si existe un acuerdo mutualmente beneficioso, afecta la forma en que las partes repartirán el excedente creado por el acuerdo. En consecuencia, la información que cada parte opta por revelar resulta en

26. La literatura de la negociación ante la asimetría de información es extensa. Para una descripción breve, véase Tirole (I988: 36I-88). 
un tradeoff de maximización de utilidades. Por una parte, revelar casualmente el precio verdadero que una parte obtiene del negocio aumenta la posibilidad de que las partes identifiquen un acuerdo mutualmente beneficioso si es que existe, pero reduce la proporción del excedente disponible que la parte obtendría si se alcanza el acuerdo. Ello le otorga a las partes un incentivo para tergiversar sus verdaderos precios de acuerdo. El saber que la contraparte tiene un incentivo para tergiversar sus verdaderos precios de esta forma implicará que ambas partes recibirán la propuesta de la contraparte con escepticismo, a menos que ello sea respaldado por sus actos (Cramton, I984: 58I). En el mejor de los casos, esto incrementará los costos de alcanzar un acuerdo. En el peor de los casos, impedirá que el mejor acuerdo posible para ambas partes sea alcanzado. Un problema similar surge cuando varias partes negocian por el mismo activo. Las reglas de negociación pueden darle a ambas partes un incentivo para tergiversar sus preferencias. Ello puede causar que el recurso no sea reasignado para su mayor y mejor uso. ${ }^{27}$

Desde hace tiempo los economistas han reconocido que los intermediarios pueden resolver los problemas derivados de las asimetrías de información. El comprometerse previamente a usar un mecanismo de asignación de excedentes de la misma forma que se obtendría contando con información perfecta puede incentivar a ambas partes a revelar su verdadera información privada. ${ }^{28}$ Una vez que la información privada ha sido revelada, ambas partes tienen incentivos para intentar una renegociación. En consecuencia, el intermediario debe tener la autoridad para exigir el cumplimiento del procedimiento para evitar que la negociación fracase.

Respecto a Internet, lo más probable es que estos problemas existan y se vayan agudizando en la medida que Internet sea cada vez más compleja. A diferencia de las redes previas, Internet no es de propiedad o administrada por una sola entidad. Consiste, en cambio, en una serie de sistemas autónomos interconectados. Debido a que cada acuerdo de

27. Para una ilustración útil, véase Kreps (I990: 280-9I).

28. La literatura en diseño de mecanismo es extensa. La contribución original es de Myerson y Satterthwaite (I983). Para un estudio, véase Fudenburg y Tirole (I991: 2433 I 8). Para una descripción accessible que se encuentra en la literatura legal, véase Talley (I994: I220-24). 
interconexión se alcanza por negociaciones en igualdad de condiciones, Internet ejemplifica con exactitud el tipo de mercado en que es probable que las asimetrías de información causen problemas. De ser así, un intermediario será a menudo la mejor solución para acordar un mecanismo de fijación de precios creíble que incentive a ambas partes a revelar la intensidad de sus preferencias.

\section{MERCADOS BILATERALES}

Los conceptos de la emergente disciplina de los mercados bilaterales incrementará aún más la posibilidad de que la intermediación juegue un rol clave en Internet. ${ }^{29}$ Desde hace tiempo que la literatura sobre los efectos económicos de las redes ha reconocido que el valor de la comunicación está en gran parte determinado por el número total de usuarios conectados a la red (Katz y Shapiro, I985: 424). Por ejemplo, el valor de una red telefónica para un usuario individual depende del número de otros usuarios que el usuario pueda contactar (Yoo, 2008: 223). Otro ejemplo clásico surgió durante la guerra entre los estándares para las videocaseteras VCR, Beta y VHS (Yoo, 2006: I 889). A pesar de los acalorados debates de la época, la mayoría de los usuarios no decidió a partir de los méritos relativos de cada tecnología ni menos de su precio. A los potenciales consumidores les importó más qué tipo de VCR sería elegido por el resto de los consumidores. En resumen, el valor para los consumidores fue casi exclusivamente determinado por cuál estándar tendría la red más amplia (Yoo, 2006: I889-92; Yoo, 2002: 278-82).

Sin embargo, algunas redes pueden estar formadas por dos tipos distintos de usuarios, con lo que el valor de la red para un usuario individual depende no sólo del número total de usuarios, sino también del número de usuarios de la otra clase. En este caso, se dice que ese mercado es un «mercado bilateral» (Armstrong, 2006: 668; Roson, 2005: I44). Tomemos como ejemplo un bar o club para solteros heterosexuales, en que el universo de consumidores está conformado por dos clases de miembros: hombres y mujeres. En este caso, el valor del club para cualquier miembro individual del mismo no está determinado por el tamaño total del

29. Para estudios de la literatura existente en materia de mercados bilaterales, véase Rochet y Tirole (2006) y Roson (2005). 
club, sino por la cantidad de miembros del sexo opuesto (Armstrong, 2006: 668; Evans, 2003: 327-28). ${ }^{30}$

Las tarjetas de crédito son otro ejemplo clásico de un mercado bilateral. Las redes de tarjetas de crédito reúnen a dos clases distintas de participantes de la red: comerciantes y clientes minoristas. El valor de una red de tarjetas de crédito para los comerciantes depende del número de clientes minoristas que pertenecen a la red. La cantidad de comerciantes que tenga la red no tiene un valor intrínseco, sólo lo tiene en la medida que ello otorgue incentivos para que clientes minoristas adicionales se integren a la misma red de tarjetas de crédito. Inversamente, para los clientes minoristas lo más importante es el número de comerciantes que integran la red y no el resto de los clientes minoristas (aunque, claro, el incremento en el número de clientes minoristas en la red constituye un incentivo para que más comerciantes se integren a ella). ${ }^{31}$

Otro ejemplo son las redes de televisión abierta, que asocian a dos clases de clientes: avisadores y espectadores. Los avisadores no se enfocan en los otros avisadores que tiene la red, sino en el número de espectadores (Yoo, 2009: 723-74). En cada uno de estos ejemplos, es el número de participantes de la otra clase en la red lo que determina el valor de la red, no el número total de usuarios de la misma.

Los mercados bilaterales tienen varias características distintivas. Por ejemplo, sufren de lo que ha sido llamado el clásico «problema del huevo o la gallina»: usando como ejemplo el mercado de las tarjetas de crédito, los clientes minoristas no usarán una tarjeta de crédito a menos que ella sea aceptada por una gran cantidad de comerciantes, mientras que los comerciantes no aceptarán recibir la tarjeta de crédito como medio de pago a menos que una gran cantidad de clientes minoristas la utilicen. Bajo estas circunstancias, un intermediario podría jugar un rol clave al usar estrategias de precio innovadoras para subir a bordo a ambas partes del mercado b lateral (Caillaud y Jullien, 2003: 3 IO-I I, 322-23; Rochet y Tirole, 2003: 990, IOI3, IOI8).

30. Aunque el valor puede aumentar dado un incremento en el número de miembros de la otra clase, el valor puede disminuir dado un aumento en el número de miembros de la misma clase, lo que podría intensificar la competencia.

3 I. Para el análisis original, véase Baxter (I983), que describe la estructura de incentivos de los participantes del mercado de las tarjetas de crédito. Véase también Rochet (2003). 
Aunque los determinantes precisos del precio óptimo son complejos, los precios cobrados a cada parte del mercado tienden a ser asimétricos, cobrándosele a una parte poco o nada por su participación (Evans y Schmalensee, 2007: I 55; Rochet y Tirole, 2003: IOI3-I7). Por ejemplo, en un bar de solteros, el precio de admisión para los hombres es mucho mayor que para las mujeres (Evans, 2003: 327). En las redes de tarjetas de crédito, a los comerciantes se les cobra por cada transacción realiza$\mathrm{da}$ a diferencia de los clientes minoristas (aunque estos podrían tener que pagar una tarifa de membresía) (Rochet y Tirole, 2003: IoI3-I4). Además, en general los precios de optimización máxima no cubren sus costos. En consecuencia, una firma que intermedia un mercado bilateral tendrá que utilizar fijación de precios Ramsey u otra forma similar de discriminación de precios para poder sostenerse. ${ }^{32}$

Adicionalmente, los precios en cada lado de un mercado bilateral son interdependientes. Cualquier fuerza que tienda a incrementar el margen de un lado en un mercado bilateral tenderá a disminuir los precios del otro lado. Ello se debe a que si los actos a un lado del mercado se tornan más rentables, entonces vale la pena promover una conexión con el otro lado. Esto lleva a lo que Rochet y Tirole han acuñado como el «principio del balancín» (2006: 659). En efecto, es muy usual que los precios en un lado de un mercado bilateral estén por debajo del costo marginal o lleguen incluso a cero (Evans y Schmalensee, 2007: I 52; Rochet y Tirole, 2006: 658-60, 665; Jullien, 2004: 8). Es más, las actividades a uno de los lados de un mercado bilateral pueden llegar a ser tan rentables que a ese lado puede encontrar que es beneficioso el subsidiar a los clientes en el otro lado del mercado, pagándoles por participar en la red (Caillaud y Jullien, 2003: 310, 3 I 4, 324; Goldberg y Epstein, 2005: 5 IO; Roson, 2005: I47-48).

La dinámica que lleva a estos subsidios cruzados es fácilmente demostrable con la economía de la televisión abierta (Yoo, 2005: 73-74). Durante décadas, el acuerdo estándar para las estaciones de televisión abierta ha consistido en pagarle a las estaciones de televisión locales para que se afilien a la red (Yoo, 2005: 74). Esto se debe a que el modelo primario de ingresos para la televisión abierta se basaba en la publicidad

32. Véase Bolt y Tieman (2006: I I 5). Roson (2005: I48); Jullien (2004: I 2-I3). Véase también Goldberg y Epstein (2005: $5 \mathrm{IO}$ ), quien argumenta que es probable que la discriminación de precios surja. 
nacional insertada en la programación provista por la cadena televisiva. El hecho de que el valor de la red para los avisadores se incrementara con el número de espectadores no hacía sino concluir que era económicamente razonable para la estación de televisión el subsidiar la conexión para los espectadores, dado que ese costo se recuperaría incrementando las tarifas de avisaje (Yoo, 2005: 74).

Igualmente interesante es la forma en que esta práctica comercial ha cambiado con el paso del tiempo. Las cadenas de televisión han empezado a variar los precios pagados, solicitándole a las estaciones más débiles aceptar pagos inferiores (Yoo, 2005: 74). Más recientemente, las cadenas han empezado a negarse a pagarles del todo a las estaciones más débiles. En cambio, han insistido en que son las estaciones más débiles las que tendrán que empezarle a pagar a la cadena si es que desean permanecer afiliados a ella (Yoo, 2005: 74). Los modelos de negocios basados en la publicidad hacen probable que este tipo de pagos se produzcan. El ejemplo de la televisión abierta demuestra cómo la magnitud e incluso la dirección de los pagos variarán en distintas estaciones y con el paso del tiempo.

La mayoría de las conclusiones obtenidas del ejemplo de la televisión abierta se aplican a la Internet moderna (Yoo, 2005: 7I-76; Yoo, 2008: 222-27). El hecho de que el flujo de ganancias por avisaje vaya hacia los proveedores de contenidos incrementa la posibilidad de que la solución óptima sea que los proveedores de contenidos efectúen pagos adicionales a los proveedores de acceso a internet para subsidiar la conexión de los usuarios finales. Aunque históricamente la práctica del backbone peering ${ }^{33}$ ha impedido el flujo de estos pagos adicionales a través de los contratos establecidos por la red, el surgimiento de nuevos acuerdos de interconexión, como el peering pagado, ${ }^{34}$ resolverá el problema, asumiendo que una regulación de neutralidad de la red no impida estas prácticas. ${ }^{35}$ Adicionalmente, la economía de los mercados bilaterales

33. Nota de los traductores. Backbone peering se refiere a la compensación de tarifas entre prestadores de servicios por interconexiones voluntarias en las redes troncales de telecomunicaciones.

34. Nota de los traductores. Peering pagado se refiere al tipo de backbone peering en que se paga por las interconexiones entre prestadores de servicios.

35. Véase Peyman Faratin y otros (2008: 58-6I). Para otros análisis aplicando la economía de los mercados bilaterales a Internet, véase Hermalin y Katz (2007); Musacchio y otros (2009); Sidak (2006: 36I-62); y Renda (2008: II-I 5). 
también enfatiza la importancia de facilitar flexibilidad de precios, de forma tal que el proveedor de la plataforma pueda incorporar a ambas partes del mercado y utilizar algún tipo de fijación de precios Ramsey para cubrir los costos.

Aunque la literatura normalmente presupone que alguna empresa servirá como tercero intermediario que reúna a ambas partes del mercado bilateral (Armstrong, 2006: 668; Rochet y Tirole, 2006: 645), ello no es necesariamente así. Como una cuestión teórica, las partes de cada lado de un mercado bilateral pueden contratar de forma descentralizada siempre y cuando exista un interfaz estandarizado para estructurar sus acuerdos. Dicho lo anterior, la presencia de actores grandes y la asimetría de información son en la intermediación el resultado más probable (Spulber, 2006: I37, I4I-48, I 52). En efecto, un ISP puede ser el único actor posicionado para acercar a ambas partes del mercado (Renda, 2008: II).

Por lo tanto, los intermediarios pueden crear nuevas soluciones a una amplia gama de potenciales problemas transaccionales asociados con negociaciones multilaterales, asimetrías de información y mercados bilaterales. Pero la intermediación también tiene sus costos. Por lo tanto, el nivel óptimo de intermediación representa una extensión de la Teoría de la Empresa de Coase y debería existir siempre que los costos de un intercambio directo excedan los costos de una intermediación (Spulber, I999: 345-47). Sin embargo, la prevalencia permanente de los intermediarios de Internet sugiere que la intermediación resulta en beneficios reales en un número significativo de casos. La complejidad del cálculo hace difícil poder predecir cuáles intermediarios serán los que otorgarán los mayores beneficios (Cotter, 2006: 73-74).

\section{SENTENCIAS JUDICIALES QUE RECONOCEN QUE LA INTERMEDIACIÓN Y LA DISCRECIÓN EDITORIAL PROMUEVEN IMPORTANTES VALORES PARA LA LIBERTAD DE EXPRESIÓN}

La discusión anterior demuestra que los intermediarios pueden promover la capacidad de los usuarios finales para obtener acceso al discurso que buscan y sólo al discurso que buscan en una amplia variedad de formas. También pueden proteger a los usuarios finales de contenido indeseado. Juegan un rol esencial al ayudar a los usuarios finales a identificar y obtener acceso al contenido deseado. Pueden ayudar a mitigar los 
problemas transaccionales que impiden que los usuarios finales accedan al contenido que buscan.

Esta parte extiende el análisis a los precedentes de la Corte Suprema sobre medios de comunicación de masas. La sección A analiza la jurisprudencia de la Corte Suprema sobre periódicos, los cuales son reconocidos por los fallos de la Corte como el estándar base. Estas sentencias rechazan firmemente todo intento de interferir con la discreción editorial de los periódicos, incluso cuando sea el único medio disponible en su área geográfica y a pesar de que el periódico, al ejercer su discreción editorial, prefiera ciertos puntos de vista por sobre otros.

Las secciones B y C analizan cómo la Corte Suprema ha aplicado estos principios a los medios de comunicación electrónicos de vanguardia anteriores a Internet: la radiodifusión y la televisión por cable. Estos precedentes reconocen uniformemente que el ejercicio de discreción editorial de los intermediarios promueve los valores de la libertad de expresión incluso cuando estos actores sencillamente sirven como conducto para opiniones ajenas o cuando ejercitan su discreción editorial para privilegiar ciertos puntos de vista.

La sección $\mathrm{D}$ analiza cómo estos principios de libertad de expresión han sido ampliados más allá de los medios de comunicación de masas hasta alcanzar a las tecnologías de common carriage, ${ }^{36}$ como la telefonía. Los casos sugieren que los common carriers tienen el derecho de ejercer algún grado de discreción editorial respecto de los mensajes que acarrean. Adicionalmente, en la medida que los common carriers deciden ofrecer más que sólo comunicaciones de persona a persona y empiezan a ofrecer contenidos de medios de masas, tienen derecho a recibir protección bajo la Primera Enmienda.

Conjuntamente, este cuerpo de sentencias judiciales otorga una poderosa demostración de cómo el ejercicio de discreción editorial de los intermediarios promueve valores importantes para la libertad de expresión. También demuestra de forma elocuente los potenciales daños a

36. Nota de los traductores. En el derecho anglosajón, common carriage es quien provee servicios de transporte de un determinado bien o personas, previa licencia, concesión o autorización del organismo regulador, sin discriminación y haciéndose responsable por las pérdidas. En términos específicos, se refiere a las empresas que prestan servicios públicos de telecomunicaciones. 
la libertad de expresión que pueden surgir si la discreción editorial es inhibida.

\section{A. LOS PERIÓDICOS COMO ESTÁNDAR BASE DE LIBERTAD DE EXPRESIÓN}

La jurisprudencia de la Corte Suprema respecto a la libertad de expresión de los periódicos ha reconocido consistentemente la naturaleza soberana de su discreción editorial. Por ejemplo, en el caso CBS, Inc. v. Democratic National Committee (en adelante, «CBS v. DNC»), ${ }^{37}$ la mayoría de la Corte contrastó la discreción editorial de los radioemisores con la de los periódicos al dejar fuera de la injerencia gubernamental la discreción editorial de los periódicos. El fallo de mayoría señaló que «el poder de un periódico de propiedad privada para promover sus propias perspectivas políticas, sociales y económicas está delimitado por sólo dos circunstancias: la primera, su aceptación por lectores - $\mathrm{y}$ por tanto avisadores - suficientes para asegurarse éxito financiero, y, la segunda, la integridad periodística de sus editores». ${ }^{38}$ La concurrencia parcial al fallo del ministro Stewart igualmente concluye que la Primera Enmienda otorga a «todo periódico la libertad para publicar lo que quiera y rechazar lo que no quiera, libre de la injerencia intrusiva del Gobierno».39

Cualquier supuesta parcialidad por parte de los periodistas no justifica una intervención gubernamental. La mayoría de la Corte indicó de forma explícita:

Para bien o para mal, los editores existen para editar; y editar es selección y elección de contenido. El que los editores, ya sea de periódicos o radioemisoras, puedan y de hecho abusen de esta facultad es algo indiscutido, pero ello no es razón para negarles la discreción que les otorgó el Congreso. El riesgo calculado de abusos se asume para preservar valores superiores. ${ }^{40}$

Incluso los ministros que se negaron a adoptar la opinión mayoritaria

37. CBS, Inc. v. Democratic Nat'l Comm. (I973), 4 I 2 U.S. 94.

38. CBS v. DNC, pág. II 7 .

39. CBS v. DNC, pág. I 45.

40. CBS v. DNC, págs. I 24-25. 
reconocieron la importancia de preservar la discreción editorial de los periódicos. En su opinión concurrente, el ministro Douglas opinó:

Sería una sorpresa para el público, como también para las editoriales y editores de periódicos, el ser informados que una oficina federal recientemente creada podría de aquí en adelante establecer «directrices» para periódicos o promulgar reglas que le darían a una agencia federal el poder dirigir a la industria editorial para garantizar que hayan opiniones equitativas respecto de todos los temas de actualidad. ${ }^{41}$

El ministro Douglas rechazó firmemente cualquier pretensión de que acusaciones de parcialidad editorial justificasen una intervención regulatoria. Luego de citar la oposición de Thomas Emerson a «forzar a los periódicos [...] a publicar todos los puntos de vista» y de Benjamin Franklin a obligar a las editoriales a abrir sus columnas «a todos y cada uno de los controversialistas» basado en el simple hecho de que «un periódico no es una diligencia a caballos», ${ }^{42}$ Douglas concluyó:

En nuestra historia, algunos periódicos han ejercido una poderosa $-\mathrm{y}$ en opinión de algunos- dañina influencia en la mente del público. Pero incluso Thomas Jefferson, quien sabía qué tan ordinaria y odiosa podía llegar a ser la prensa, nunca imaginó interferir en ella. Pues él creía que el control gubernamental de la prensa era el peor de dos males. ${ }^{43}$

Entonces, Jefferson concluyó que el «estado de podredumbre» en el que habían caído los periódicos seguía siendo «un mal para el cual no hay remedio, nuestra libertad depende de la libertad de prensa». ${ }^{44}$

El hecho de que la discreción editorial que ejercen las empresas periodísticas pueda constituir una forma de censura privada no justificaba una intervención regulatoria. El ministro Douglas indicó: «Por supuesto que existe censura privada en el periodismo. Pero para cada editor que suprima un hecho, hay varios que lo publicarán. Pero si el Gobierno es el censurador, será un mandato administrativo, y no la libertad de elección, lo que predomine». ${ }^{45}$ Continua Douglas: «Tanto las emisiones de

\footnotetext{
4I. CBS v. DNC, págs. I 50-5I.

42. $C B S v$. DNC, págs. I $5 \mathrm{I}^{-} 52$.

43. CBS v. DNC, págs. I 52-53.

44. CBS v. DNC, pág. I 53.

45. CBS v. DNC, pág. I 53.
} 
noticias en televisión como en la radio con frecuencia inclinan las noticias hacia una dirección u otra... tal como lo hacen los periódicos, las revistas y otros estamentos de la prensa. Los estándares de la televisión, la radio, los periódicos o las revistas — ya sean de excelencia o mediocridad- escapan al alcance del Gobierno». ${ }^{46}$

El ministro Brennan en su voto disidente, al cual adhirió el ministro Marshall, concluyó igualmente que todo intento de obligar a los periódicos a llevar anuncios editoriales violaría la Primera Enmienda ${ }^{47}$ Por lo tanto, a pesar de las discrepancias de la Corte en otros asuntos, ésta fue unánime para ratificar la importancia de preservar la discreción editorial de los periódicos y para rechazar los argumentos que justificaban restringirla debido a la supuesta parcialidad de los editores.

Posteriormente, ese mismo año, la Corte Suprema ratificó estos principios en Miami Herald Publishing Co. v. Tornillo, ${ }^{48}$ el caso que es probablemente la confirmación más definitiva de la Corte sobre la importancia de preservar la discreción editorial de los periódicos. En ese caso, la Corte unánimemente anuló una norma sobre derecho a réplica del Estado de Florida porque ello constituía una «intrusión en la función de los editores» inaceptable..$^{49}$ La Corte señaló:

Un periódico es mucho más que un receptáculo vacío o un conducto para noticias, comentarios y publicidad. La elección de qué contenidos incluir en el periódico, y las decisiones sobre las limitaciones del tamaño y contenido del periódico, así como el tratamiento de asuntos públicos y de los funcionarios públicos — sea justo o injusto- constituye un ejercicio de control y criterio editorial. ${ }^{50}$

Esta conclusión ni siquiera fue afectada por la ola de quiebras de

46. CBS v. DNC, pág. I 55; cf. CBS v. DNC, pág. I 65: «El poder del Gobierno para censurar la prensa fue abolido para que ésta pudiera permanecer siempre libre de la censura del Gobierno. Sólo una prensa libre y sin restricciones puede exponer efectivamente el engaño en el Gobierno». En Yale Broad. Co. v. FCC (I973), 4I4 U.S. 9I4, págs. 9I6-I7, J. Douglas, voto disidente, discute «el inevitable peligro resultante de ubicar los poderes [de censura] en manos gubernamentales».

47. CBS v. DNC, pág. I82, n. I 2.

48. Miami Herald Publ'g Co. v. Tornillo (I974), 4I 8 U.S. 24I.

49. Miami Herald Publ'g Co. v. Tornillo, pág. 258.

50. Miami Herald Publ'g Co. v. Tornillo, pág. 258. 
periódicos que convirtió a la mayoría de las ciudades en ciudades con un solo periódico. ${ }^{51}$ Tampoco el hecho de que los periódicos pudieran caer dentro de la «homogeneidad de la discreción, comentario y análisis editorial» o que estuvieran sujetos a «los abusos de parcialidad y la manipulación periodística». ${ }^{2}$ En palabras de la Corte, «una prensa responsable constituye sin lugar a dudas una meta deseable, pero la responsabilidad de la prensa no está ordenada por la Constitución y como varias otras virtudes, no puede ser legislada». ${ }^{53}$

La opinión concurrente del ministro White repetía idénticas preocupaciones. Usando un lenguaje que luego adoptaría la totalidad de la Corte,${ }^{54}$ el ministro White empezó señalando:

De acuerdo con nuestra jurisprudencia vigente, la Primera Enmienda crea una barrera entre el gobierno y los medios impresos que es virtualmente impasable en lo que dice relación con una intervención gubernamental, previa a la publicación, en lo que se refiere a noticias y contenido editorial. Un periódico o revista no es una empresa de servicios públicos sujeta a una regulación gubernamental «razonable» respecto de asuntos que afectan el ejercicio del criterio editorial sobre qué debe publicarse. Sin importar que tan conveniente podría considerarse el objetivo de controlar a la prensa, preferíamos el «poder de la razón aplicado a través de la discusión pública» y permanecemos intensamente escépticos de las medidas que le permitirían al gobierno insinuarse en las oficinas editoriales de la prensa nacional. ${ }^{55}$

La potencial falta de equidad o imparcialidad no justifica una intervención gubernamental:

Obviamente, la prensa no siempre es precisa, o incluso responsable, y puede obviar un debate íntegro y justo sobre asuntos de interés público. Pero el equilibrio establecido por la Primera Enmienda respecto de la prensa es que la sociedad debe asumir el riesgo de que ocasionalmente los debates sobre asuntos de vital importancia puedan no ser integrales

5 I. Miami Herald Publ'g Co. v. Tornillo, págs. 249, 25 I y 253.

52. Miami Herald Publ'g Co.v. Tornillo, pág. 250.

53. Miami Herald Publ'g Co. v. Tornillo, pág. 256.

54. Véase Neb. Press Ass'n v. Stuart (I976), 427 U.S. 539, págs. 560-6I.

55. Miami Herald Publ'g Co. v. Tornillo, pág. 259, J. White, voto concurrente, cita a Whitney v. California (I927), 274 U.S. 357, pág. 375, J. Brandeis, voto concurrente. 
y que no todos los puntos de vista serán expresados. Cualquier otro arreglo - cualquier otro sistema que reemplazaría el control privado de la prensa por la pesada mano de la intrusión estatal- convertiría al gobierno en el censor de lo que la gente lee y sabe. ${ }^{56}$

Las siguientes sentencias de la Corte hicieron eco de la inviolabilidad de la discreción editorial de los periódicos. Por ejemplo, en Pittsburgh Press Co. v. Human Relations Commission, ${ }^{57}$ la Corte «reafirmó inequívocamente la protección conferida a la discreción editorial y a la libre expresión de perspectivas tanto de éste como de otros asuntos, sin importar qué tan controversial lo sea». ${ }^{58}$ El voto disidente del ministro Stewart, al cual adhirió el ministro Douglas, hacía suyo este punto vista, destacando que ninguna «agencia gubernamental — local, estatal o federal- puede decirle anticipadamente a un periódico lo que puede o no publicar». ${ }^{59}$

Igualmente, en FCC $v$. League of Women Voters of California (en adelante, «FCC $v$. League»), ${ }^{60}$ la Corte reconoció que una regulación que busque garantizar «una presentación equitativa de la información respecto a asuntos de interés público... nunca se ha permitido respecto de los medios impresos». ${ }^{61} \mathrm{La}$ Corte adicionalmente advirtió que los periódicos gozan «de la más absoluta libertad para abogar sus propias posiciones sin presentar los puntos de vista opuestos». ${ }^{62}$

La Corte ratificó nuevamente la importancia de preservar la independencia editorial de los periódicos en Turner Broadcasting System, Inc. $v$. FCC (en adelante, «Turner v. FCC»), ${ }^{63}$ al notar que «[el caso] Tornillo confirmó un principio esencial: la Primera Enmienda protege la independencia editorial de la prensa». ${ }^{64}$ La Corte reiteró «que una regulación sobre derecho a réplica... es una intromisión inaceptable en el control y

56. Miami Herald Publ'g Co. v. Tornillo, pág. 260.

57. Pittsburgh Press Co. v. Human Relations Comm'n (I973), 4I 3 U.S. 376.

58. Pittsburgh Press Co. v. Human Relations Comm’n, pág. 39I.

59. Pittsburgh Press Co. v. Human Relations Comm'n, pág. 400.

60. FCC v. League of Women Voters of Cal. (I984), 468 U.S. 364.

6I. FCC v. League, pág. 377.

62. FCC v. League, pág. 380.

63. Turner v. FCC (1994), 5 I 2 U.S. 622.

64. Turner v. FCC, pág. 653. 
discreción editorial de los periódicos». ${ }^{65} \mathrm{Al}$ comparar los monopolios de la prensa con los monopolios de la televisión por cable, la Corte explícitamente distinguió que el mero hecho de que un periódico fuera el único medio de una ciudad no justificaba el exigirle que publicara puntos de vista adicionales, enfatizando que «un periódico, sin importar qué tan firme sea su monopolio local, no posee el poder para obstruir el acceso de los ciudadanos a otras publicaciones competidoras». ${ }^{66}$

A mayor abundamiento, en Arkansas Education Television Commission v. Forbes,${ }^{67}$ la Corte reconoció que el «elegir entre oradores que tienen puntos de vista diversos» representa una parte esencial de lo que hacen los editores de periódicos (y emisoras). ${ }^{68} \mathrm{Al}$ repetir el lenguaje de CBS v. DNC, la Corte confirmó que el hecho de que los editores prefieran ciertos puntos de vista y rechacen otros no justifica el imponer regulación: «El que los editores puedan y de hecho abusen de este poder es algo indubitado, pero los calculados riesgos de abusos se asumen para preservar valores superiores». ${ }^{69}$

\section{B. LA IMPORTANCIA Y LÍMITES DE LA DISCRECIÓN EDITORIAL EJERCIDA POR LOS EMISORES}

Así, los precedentes de la Corte Suprema reconocieron uniformemente el rol esencial que juega salvaguardar la discreción editorial para promover y preservar la libertad de expresión. Como sugieren frases como «libertad absoluta» ${ }^{70} \mathrm{y}$ «una barrera virtualmente impasable», ${ }^{71}$ esta discreción es inviolable incluso cuando un periódico en particular ejerciera un poder de facto monopólico o sin importar qué tan parcial o sesgada fueran sus políticas. ${ }^{72}$

65. Turner v. FCC, pág. 653, cita Miami Herald Publ'g Co. v. Tornillo, pág. 258.

66. Turner v. FCC, pág. 656.

67. Ark. Educ. Television Comm'n v. Forbes (I998), 523 U.S. 666.

68. Ark. Educ. Television Comm'n v. Forbes, pág. en 673.

69. Ark. Educ. Television Comm'n v. Forbes, pág. 673-74, cita CBS v. DNC, págs. $\mathrm{I} 24 y \mathrm{I} 25$.

70. FCC v. League, pág. 377.

7I. Miami Herald Publ'g Co. v. Tornillo, pág. 259.

72. Véase Ark. Educ. Television Comm'n v. Forbes, págs. 673-74; Miami Herald 
La Corte prontamente sería llamada a determinar el alcance de estos principios aplicados a la radioemisión, la primera forma importante de comunicación electrónica de masas que apareció. Las decisiones de la Corte emplearon un lenguaje bastante similar al de sus precedentes sobre periódicos, ofreciendo varias afirmaciones sobre la importancia de otorgarle a las radioemisoras discreción editorial. De hecho, las decisiones sobre las radioemisoras claramente consideran el estándar para los periódicos como la base contra la cual las regulaciones sobre radioemisión deben medirse.

Sin embargo, la Corte reconoció dos excepciones que justificaban mantener regulaciones que eran claramente impermisibles respecto de los periódicos: la supuesta escasez de espectro electromagnético y la supuesta ubicuidad y accesibilidad de la programación de radio emitida. Investigaciones posteriores han levantado serias dudas sobre la viabilidad conceptual de estas excepciones incluso respecto a la radioemisión. Pero lo que es más importante, la Corte ya ha determinado que el raciocinio tras estas excepciones es inaplicable a Internet. Por lo tanto los precedentes ya han cerrado la posibilidad de que estas excepciones puedan justificar el imponer restricciones a la discreción editorial de los prestadores de servicios de Internet.

\section{LA IMPORTANCIA DE LA DISCRECIÓN EDITORIAL DE LAS RADIOEMISORAS}

La Corte Suprema ha reconocido desde hace tiempo que la discreción editorial ejercida por las radioemisoras está al servicio de valores expresivos importantes que se verían comprometidos si éstas fueran obligadas a poner sus redes a disposición de todos los anunciantes de forma indiscriminada. La Corte mostró el primer desarrollo extensivo de estos principios en el caso CBS v. DNC, cuando rechazó el argumento de que la negación de una radioemisora a vender tiempo para avisaje editorial violaba las leyes federales de telecomunicaciones o la Primera Enmienda. ${ }^{73}$

La Corte comenzó su rechazo a la supuesta infracción estatutaria,

Publ'g Co. v. Tornillo, págs. 249-5I, 253, 256 y 260; CBS v. DNC, págs. I24-25; CBS v. DNC, págs. I 52-53, I 55, J. Douglas, voto concurrente en el fallo.

73. CBS v. DNC, pág. I 2 I. 
examinando la historia legislativa de la Ley de Radios de $1927,{ }^{74}$ que estableció los principios básicos que rigen las normas sobre radiodifusión. Como señaló la Corte, al dictar la Ley de Radios de I927, «el Congreso trató especialmente - y rechazó explícitamente- el argumento de que las emisoras de radiodifusión debían abrirse de forma no discriminatoria para cualquiera que quisiera referirse a asuntos públicos». ${ }^{75}$ En cambio, «respecto de la discusión de asuntos públicos, el Congreso optó por darle al titular de la concesión una amplia discreción periodística». ${ }^{76}$

Algunos miembros del Congreso alegaron que no colocar límites a la discreción editorial de las radioemisoras les daría un poder de «censura privada». ${ }^{77}$ Para combatir esta preocupación, el proyecto informado a la Comisión de Comercio del Senado incluyó una norma que habría limitado la discreción editorial de las radioemisoras al exigirles informar todo discurso político de forma no discriminatoria. ${ }^{78} \mathrm{El}$ senador Dill, el principal autor de la Ley de Radios de 1927, presentó una modificación eliminando la norma, alegando que "parecía poco prudente exigirle a la radioemisora estar sujeta al obstructivo control de ser un common carrier y obligarla a aceptar cualquier cosa que se le ofrezca siempre y cuando se le pague el precio respectivo». ${ }^{79} \mathrm{El}$ senador Dill también enfatizó la dificultad de poder administrar un derecho al acceso no discriminatorio. ${ }^{80}$ En vez de crear un derecho de acceso para el discurso político, el Congreso estableció una norma más limitada que sencillamente le exigía a las radioemisoras que aceptaran avisaje de un candidato a un puesto público, el darle iguales oportunidades a otros candidatos para el mismo puesto. ${ }^{81}$

74. Radio Act of 1927, ch. I69, 44 Stat. I I62 (codificado en 47 U.S.C. $\$ 3$ I 5 (a)).

75. CBS v. DNC, pág. I05.

76. CBS v. DNC, pág. I05.

77. CBS v. DNC, pág. I05, cita a H.R. REP. NO. 69-404, en I 8 (I927) (informe de la minoría); 67 CONG. REC. 5483, 5484 (I926) (declaración de Rep. Davis).

78. CBS v. DNC, pág. I05-6.

79. CBS v. DNC, pág. I06, cita a 67 CONG. REC. I2,502 (I926) (declaración de Sen. Dill).

80. CBS v. DNC, pág. I06-07, cita a 67 CONG. REC. I2,504 (I926) (declaración de Sen. Dill).

8I. CBS v. DNC, pág. I07, cita a Radio Act of I927, ch. I69, $\mathbb{I}$ I8, 44 Stat. II62, I I70 (codificado en 47 U.S.C. $\mathbb{S}$ I $5(\mathrm{a})$ ). 
Cuando el Congreso reemplazó el Ley de Radios de I927 con la Ley de Comunicaciones de I934, le dio la misma alta prioridad al ejercicio de las radioemisoras de su discreción editorial. ${ }^{82} \mathrm{Al}$ volver a adoptar la norma de la Ley de Radios de 1927 antes citada, el Congreso rechazó una propuesta que le habría exigido a una radioemisora el permitir que su estación fuese usada para presentar los aspectos de un asunto de interés público que fuera a votarse en la próxima elección, para darle igualdad de oportunidades a puntos de vista opuestos respecto del asunto en particular. ${ }^{83}$ Según la Corte, la promulgación de dicha norma «le habría impuesto a las radioemisoras una obligación restringida de entregar sus micrófonos a personas que quisieran referirse a ciertos asuntos públicos». ${ }^{84} \mathrm{Y}$ lo que es aún más importante, el Congreso promulgó una norma que disponía expresamente que «una persona que realizase radiodifusión no sería considerada un common carrier». ${ }^{85}$

El compromiso del Congreso de proteger la discreción editorial de las radioemisoras se vio reforzado por ciertas normas estatutarias que le impedían a la FCC censurar a las radioemisoras o interferir con sus derechos de libre expresión. ${ }^{86}$ La Corte señaló que «siendo coherente con esa filosofía, en varias ocasiones la Comisión ha determinado que ningún individuo o grupo tiene el derecho de controlar el uso de las instalaciones de radiodifusión». ${ }^{87}$ La Corte interpretó que la Ley de Comunicaciones de 1934 «evidenciaba un deseo legislativo de preservar los valores del periodismo privado» y de «permitir que la radioemisión privada se desarrollara con la más amplia libertad de prensa en conformidad con sus obligaciones públicas». ${ }^{88}$ "Dado que es físicamente imposible el darle tiempo a todos los puntos de vista, se le otorgó a la radioemisora el

82. Communications Act de 1934 , ch. 652, 48 Stat. I064 (codificado en 47 U.S.C. $\mathbb{S}$ I 53 ).

83. CBS v. DNC, pág. 107-8 y n. 4, cita Hearings on S. 29 Io Before the S. Comm. on Interstate Commerce, $73 \mathrm{~d}$ Cong., $2 \mathrm{~d}$ Sess. I9 (I934).

84. CBS v. DNC, pág. I07-8, cita a H.R. REP. NO. 73-I9I8, pág. 49 (I934) (Conf. Rep.).

85. CBS v. DNC, pág. Io8-9, cita a Communications Act of $1934, \mathbb{S} 3(\mathrm{~h}), 48$ Stat. en I066 (codificado en 47 U.S.C. $\$$ I 53 (IO)).

86. CBS v. DNC, pág. I Iо, cita a 47 U.S.C. $\$ 326$.

87. CBS v. DNC, pág. II 3 .

88. CBS v. DNC, pág. Iо9-ıо. 
derecho a ejercer discreción editorial». ${ }^{89} \mathrm{Si}$ bien esta discreción editorial plantea la posibilidad de que «una sola persona o grupo pueda(n) situarse en una posición que les permite censurar el material transmitido al público», ${ }^{90}$ "el Congreso parece haber concluido que de estas dos opciones - censura privada versus oficial — la censura gubernamental sería más penetrante, más autoindulgente, las más difícil de restringir y por tanto lo que debe evitarse». ${ }^{91}$

Adicionalmente, al discutir sobre la Primera Enmienda, la Corte enfatizó el beneficio para la libre expresión del ejercicio de la discreción editorial de las radioemisoras. La Corte rechazó el argumento de que darle a los oradores acceso irrestricto a las redes de radiodifusión promovería la libertad de expresión, y de pasó revocó «la visión de la Corte de Apelaciones de que cada potencial orador es el 'mejor juez' de lo que la audiencia debe escuchar o de hecho el mejor juez de los méritos de sus puntos de vista». ${ }^{92}$ La Corte concluyó:

Toda la tradición y experiencia periodística indica lo contrario. Para bien o para mal, la edición es para lo cual existen los editores; y editar es seleccionar y elegir material. El que los editores puedan y de hecho abusen de su poder es indudable, pero dicha razón no justifica denegarles la discreción otorgada por el Congreso. Los riesgos calculados de abuso se toman en consideración para promover valores superiores. La existencia de estos riesgos no es nueva; los autores de la Carta de Derechos aceptaron el hecho de que estos riesgos eran males para los cuales no existían otros remedios aceptables más que un espíritu de moderación y un sentido de responsabilidad — y civilidad - de parte de quienes ejercen la garantizada libertad de expresión. ${ }^{93}$

La única parte de la sentencia que representaba a una pluralidad de la Corte tocaba temas similares. La historia legislativa indicaba «un deseo de que los licenciatarios mantuvieran un rol periodístico tradicional». ${ }^{94}$

89. CBS v. DNC, pág. I I I.

90. CBS v. DNC, pág. I04, cita a Hearings on H.R. 7357 Before the H. Comm. on the Merchant Marine and Fisheries, 68th Cong., Ist Sess. 8 (I924).

91. CBS v. DNC, pág. I05.

92. CBS v. DNC, pág. I24.

93. CBS v. DNC, pág. I24-25.

94. CBS v. DNC, pág. I 16. 
Al establecer la norma estatutaria que le prohibía al gobierno «interferir con el ejercicio de la libertad de expresión sobre las frecuencias de radiodifusión, el Congreso se abstuvo deliberadamente de despojar a las radioemisoras de su control sobre la selección de opiniones». ${ }^{95}$ Estas normas estatutarias «muestran la evidente intención del Congreso de mantener una medida importante de independencia editorial para el licenciatario de radiodifusión». ${ }^{96}$ La mayoría concluyó:

Nos sería anómalo declarar, en nombre de la promoción de la garantía constitucional a la libre expresión, que las decisiones cotidianas de los licenciatarios de radiodifusión estuvieran sujetas a las restricciones propuestas por los demandados. El hacerlo en nombre de la Primera Enmienda sería una contradicción. De varias formas, la discreción periodística se perdería en las rígidas limitaciones que la Primera Enmienda le impone al Gobierno. ${ }^{97}$

El juez Stewart concurrió señalando que el obligar a las radioemisoras a desarrollar un «sistema no discriminatorio para controlar el acceso es precisamente lo que el Congreso buscaba impedir a través de la Sección 3 (h) de la Ley». ${ }^{98}$

La Corte volvió a resaltar la importancia de la discreción editorial de las radioemisoras en FCC $v$. League al anular un estatuto que prohibía «el poder editorializar» a las estaciones de televisión educacionales y sin fines de lucro que recibieran donaciones de la Corporation for Public Broadcasting. ${ }^{99} \mathrm{Al}$ fallar de esa forma, la Corte rechazó los argumentos de que el interés por asegurar una cobertura equilibrada de los asuntos públicos justificaba el anular la discreción editorial de las radioemisoras. ${ }^{100} \mathrm{La}$ Corte estimó que «las radioemisoras realizan una forma de actividad comunicacional esencial e independiente. A diferencia de los common carriers, en virtud de la Primera Enmienda las radioemisoras tienen derecho a ejercer la más amplia libertad periodística en conformi-

95. CBS v. DNC, pág. I 16.

96. CBS v. DNC, pág. I 6.

97. CBS v. DNC, pág. I 20-I.

98. CBS v. DNC, pág. I40.

99. Public Broadcasting Amendments Act of I98 I, Pub. L. No. 97-35, 95 Stat. 730.

гоo. FCC v. League, págs. 378-80. 
dad con sus deberes públicos». ${ }^{101}$ La Corte además concluyó: «En efecto, si el interés del público de recibir una presentación equilibrada de distintos puntos de vista debe cumplirse completamente, debemos necesariamente depender en gran parte de la iniciativa y criterio editorial de las radioemisoras». ${ }^{102}$ La Corte luego notó que «la prensa, de la cual la industria de radiodifusión sin lugar a dudas forma parte, tiene una responsabilidad histórica y dual en nuestra sociedad, de informar y rendir juicio crítico a los asuntos públicos». ${ }^{103}$ El prohibir que las estaciones de televisión pública puedan editorializar representa una «inculcación sustancial de las importantes libertades de prensa que la Primera Enmienda protege celosamente». ${ }^{104}$

De igual forma, en Turner v. FCC la Corte advirtió que «nuestros casos han reconocido que la regulación gubernamental sobre los contenidos de la programación de las radioemisoras debe ser limitada, y que los licenciatarios de radioemisión deben mantener una abundante discreción sobre sus decisiones de programación». ${ }^{105}$

La Corte reiteró esta preocupación en Ark. Educ. Television Comm'n v. Forbes, al confirmar la decisión de una cadena de televisión pública estatal de excluir a un candidato de un tercer partido al Congreso de participar en un debate. ${ }^{106}$ La premisa clave del análisis de la Corte fue que "cuando un radioemisor público ejerce su discreción editorial en la selección y presentación de su programación, realiza actos expresivos». ${ }^{107} \mathrm{La}$ importancia de preservar esta discreción justificó confirmar la decisión del radioemisor de excluir del debate al candidato del tercer partido: «En el caso de la transmisión televisiva, otorgarle a terceros amplios derechos de acceso sería antiético, como regla general, respecto de la discreción que las estaciones y su grupo editorial deben ejercer para cumplir con sus fines periodísticos y sus obligaciones estatutarias». ${ }^{108}$

La Corte desarrolló este argumento:

Iог. FCC v. League, pág. 378, cita CBS, Inc. v. FCC (I98I), 453 U.S. 367, pág. 395. I02. FCC v. League, pág. 378.

I03. FCC v. League, pág. 382.

I04. FCC v. League, pág. 402.

105. Turner v. FCC, pág. $65 \mathrm{I}$.

ı06. Ark. Educ. Television Comm'n v. Forbes, pág. 669.

I07. Ark. Educ. Television Comm'n v. Forbes, pág. 674.

Io8. Ark. Educ. Television Comm'n v. Forbes, pág. 673. 
El Congreso ha rechazado el argumento de que las «instalaciones de radioemisión deben ser abiertas en términos no selectivos para cualquier persona que desee hablar sobre asuntos públicos». En cambio, las emisoras televisivas gozan de la «más amplia libertad periodística» en consonancia con sus responsabilidades públicas. Tanto los emisores públicos como privados no sólo pueden, sino que se les exige, ejercer una discreción editorial sustancial en la selección y presentación de su programación». ${ }^{109}$

El hecho de que las radioemisoras a menudo solo sirvan como el conducto para el discurso de terceros no afecta este análisis. La Corte señaló que «aunque algunas decisiones programáticas a menudo implican la elaboración de un discurso para terceros, aun así esas decisiones constituyen actos de comunicación». ${ }^{110}$

La posibilidad de que las radioemisoras discriminaran entre distintos oradores no justifica una intervención regulatoria sencillamente porque «una radioemisora por su naturaleza facilitará la expresión de ciertos puntos de vista en vez otros». ${ }^{111}$ Invocando la autoridad del precedente de CBS v. DNC, la Corte detalló que «las radioemisoras a menudo deben elegir entre oradores que expresas diversos puntos de vista. 'El que los editores — ya sea de periódicos o radioemisoras - puedan y de hecho abusen de este poder es indudable', pero 'los riesgos calculados de abusos se asumen para preservar valores superiores. ${ }^{112}$ Cualquier intervención gubernamental en definir los criterios de acceso «arriesgaría implicar a los tribunales en juicios que deben ser dejados al ejercicio de la discreción periodística». ${ }^{113}$

\footnotetext{
109. Ark. Educ. Television Comm’n v. Forbes, pág. 673, cita CBS v. DNC, pág. 105,

I Iо. Ark. Educ. Television Comm'n v. Forbes, pág. 674.

I I I. Ark. Educ. Television Comm'n v. Forbes, pág. 674.

I I2. Ark. Educ. Television Comm'n v. Forbes, pág. 673-4, cita CBS v. DNC, pág. I 24, I 25 .

II3. Ark. Educ. Television Comm'n v. Forbes, pág. 674.
} I IO. 


\section{EL CASO RED LION V. FCC: LA ESCASEZ COMO JUSTIFICACIÓN PARA LIMITAR LA DISCRECIÓN EDITORIAL}

Los precedentes sobre radiodifusión de la Corte Suprema reconocen valores importantes de la libertad de expresión promovidos por el ejercicio de la discreción editorial de las radioemisoras. Estos valores son atendidos cuando las radioemisoras ejercitan su discreción editorial a favor de un punto de vista en particular o cuando sirven sencillamente como un conducto para la expresión de terceros. Si la Corte se hubiera detenido acá, cualquier restricción sobre la capacidad de las radioemisoras de servir como intermediarias dañaría los principios de libre expresión reconocidos por la Corte y en consecuencia tendrían que haberse restringido fuertemente, o haberlos prohibido derechamente.

A pesar de la confirmación vigorosa de la discreción editorial de las radioemisoras por la Corte, ésta también ha confirmado desde hace tiempo las leyes que obligan a las radioemisoras a servir como conducto para la expresión de terceros que presuntamente hubieran sido invalidadas si hubieran regido a los periódicos. ${ }^{114}$ La Corte normalmente justifica estas decisiones invocando la así llamada doctrina de las escasez, planteada originalmente por la Corte en NBC, Inc. v. United States (en adelante, «NBC v. US»). ${ }^{115}$ En la mayoría de los casos, expresarse no es un juego de suma cero en que el discurso de una persona desplaza al de otra. En ese caso, quienes se ven enfrentados a expresiones respecto de las cuales no están de acuerdo son libres de ofrecer su propio punto de vista. En resumen, la solución clásica para mala expresión es más expresión. ${ }^{116}$

I I4. Véase Red Lion v. FCC, pág. 367, que afirmó normas de la FCC que imponen requerimientos de un derecho de respuesta a los emisores que eran notablemente similares a las normas posteriormente anuladas en Miami Herald Publ'g Co. v. Tornillo. Véase también CBS, Inc. v. FCC (I98I), 453 U.S. 367. De hecho, la Corte ha señalado que «de todas las formas de comunicación, la radiodifusión es la que ha recibido la protección de la Primera Enmienda más limitada». FCC v. Pacifica Found. (1978), 438 U.S. 726, pág. 748; Turner v. FCC, pág. 637: «Es cierto que nuestros casos han permitido una regulación más intrusiva de los oradores de la radiodifusión que de los oradores en otros medios".

I I 5. NBC, Inc. v. United States (I943), 3 I 9 U.S. I90.

I 16. Para el enunciado clásico de este principio, véase Whitney v. California (I927), 274 U.S. 357, pág. 377: «Si hay tiempo para exponer a través del debate la falsedad y las falacias... el remedio a ser aplicado es más libertad de expresión, no silencio forzado». 
Sin embargo, respecto de la radiodifusión, la Corte estimó que «ciertos hechos básicos respecto de la radio como un medio de comunicación» hacían insuficiente una respuesta de ese tipo. ${ }^{117}$ Como la Corte advirtió, las «instalaciones radiales son limitadas; no están disponibles para todos quienes deseen usarlas; el espectro radioeléctrico sencillamente no es lo suficientemente grande como para incluir a todos. Existe una limitación natural fija respecto del número de estaciones que pueden funcionar sin interferir entre ellas». ${ }^{118}$ Es por lo tanto inevitable que algunas puedan transmitir y otras no, y la decisión de permitirle a cualquiera emitir necesariamente impide que otros lo hagan.

Una serie de sentencias de tribunales inferiores que impidieron que el Secretario de Comercio asignara frecuencias específicas a las radioemisoras le otorgó a la Corte lo que ella vio como un experimento natural en el uso no regulado del espectro. «El resultado fue confusión y caos. Cuando todos están al aire, nadie puede ser oído». ${ }^{119}$ Ello llevó a la Corte a concluir que alguna forma de regulación gubernamental debía tolerarse para no dilapidar el espectro como recurso. ${ }^{120}$ La Corte reiteró estos argumentos al discutir la aplicación de la Primera Enmienda a la radiodifusión: «A diferencia de otras formas expresivas, por su naturaleza la radio no está disponible para todos. Ésa es su característica única, y por ello, a diferencia de otras formas expresivas, está sujeta a regulación gubernamental». ${ }^{121}$

Así la doctrina de la escasez convirtió a la libertad de expresión en un juego de suma cero en que la mala expresión no siempre se enfrentaba con más expresión y el permitirle a una persona expresarse inevitablemente restringía la capacidad de otra para hacerlo. El enfocar la libertad de expresión de este modo dejó a la Corte metida en un dilema. El confirmar la asignación gubernamental de las licencias de radiodifusión necesariamente significaba autorizar una restricción a la capacidad de algunos de poder expresarse por radiodifusión. La alternativa significaba que nadie jamás podría expresarse de esta forma. Al verse enfrentada a

I I7. NBC v. US, pág. en 2 I 3 .

I $18 . N B C v$. US, pág. en 2 I 3 .

I I9. NBC v. US, pág. en 2 I 2.

I20. $N B C v$. US, pág. en 213, 2 I 6.

I2I. NBC v. US, pág. 226. 
elegir entre un mundo en que nadie pudiera expresarse y uno en que sólo algunos pudieran hacerlo, la Corte concluyó que la Primera Enmienda apoyaba optar por lo segundo. En resumen, el permitir que ciertos oradores pudieran aprovecharse de esta nueva tecnología resultaría una mejor promoción de los valores de la libertad de expresión que el negarle a todos la oportunidad de expresarse.

En consecuencia, la Corte concluyó que el mero requisito de que cada radioemisora tenga una licencia previa para poder comunicar no infringe la Primera Enmienda. ${ }^{122}$ Ello a su vez planteó interrogantes respecto de cómo se asignarían las licencias y cómo el gobierno elegiría a quienes desearan transmitir. La Corte rechazó el argumento del rol limitado del gobierno como un "policía de tránsito", exclusivamente interesado en fiscalizar la ingeniería y aspectos técnicos de las comunicaciones por radio y asegurándose que las estaciones no interfirieran entre ellas. ${ }^{123} \mathrm{La}$ Corte, en cambio, concluyo que la Ley de Radios de 1927 le impone al gobierno la «carga de determinar la composición de ese tráfico». ${ }^{124} \mathrm{El}$ hecho de que «las instalaciones de radio no sean suficientemente amplias para acomodar a todos quienes deseen usarlas» implicaba que «debían desarrollarse métodos para elegir entre los muchos que solicitan la licencia». ${ }^{125}$ El gobierno tendría que hacerlo basado en qué solicitante "prestaría el mejor servicio posible a la comunidad cubierta por sus transmisiones». ${ }^{126}$

Estas reglas desarrolladas en NBC $v$. US se referían a la estructura de la industria de radiodifusión (específicamente a las condiciones bajo las cuales las estaciones individuales se afiliaban a las redes de radiodifusión). Como tal, el caso no le dio la oportunidad a la Corte para pronunciarse sobre cómo «la carga de determinar la composición de ese tráfico» determinaría a su vez qué solicitante prestaría el mejor servicio posible. La Federal Radio Commission (en adelante, «FRC») y su sucesora, la FCC, basaron en gran parte sus decisiones de asignación de

I22. NBC v. US, pág. 227.

I 23. NBC v. US, pág. $215,217$.

I 24. NBC v. US, pág. 2 I 6.

I25. NBC v. US, pág. 2 I 6.

I 26. NBC v. US, pág. 226, cita FCC v. Sanders Bros. Radio Station (I940), 309 U.S. 470, pág. 475 . 
licencias en los contenidos transmitidos (Yoo, 2003: 260-66). La Corte Suprema le otorgó a esta forma de asignación su visto bueno implícito en el caso Red Lion Broadcasting, Co. v. FCC (en adelante, «Red Lion v. FCC» $)^{127}$ que confirmó la constitucionalidad de las decisiones de la FCC y sus reglas, exigiéndole a las radioemisoras otorgar un derecho a réplica siempre que una radioemisora patrocinara políticamente a un candidato a un cargo público o transmitiera un ataque personal contra la honestidad, carácter o integridad de alguien. ${ }^{128}$

En Red Lion v. FCC la Corte revisó la historia previamente discutida en $N B C v$. US ${ }^{129}$ y concluyó igualmente que con la radiodifusión «sólo una pequeña fracción de aquellos con recursos e inteligencia pueden aspirar a comunicarse por radio al mismo tiempo si es que podrá haber comunicación inteligible». ${ }^{130}$ Por lo tanto, «debido a que las frecuencias reservadas para la radiodifusión pública existen en cantidades limitadas, era esencial que el gobierno pudiera negarle totalmente el poder transmitir a algunas radioemisoras porque sólo hay espacio para unas pocas». ${ }^{131}$ En otras palabras, "solo unos pocos pueden ser autorizados y el resto deberá ser excluido del espectro». ${ }^{132}$ Así, no infringe la Primera Enmienda el exigirle a todas las radioemisoras tener una licencia antes de expresarse. Cualquiera otra conclusión afectaría los valores de libertad de expresión al impedir que todos pudieran desarrollar expresión radiodifundida. La Corte notó: «Sería extraño que la Primera Enmienda, que busca proteger y promover las comunicaciones, le impidiera al gobierno el poder implementar las comunicaciones radiales... limitando el número de licencias para no saturar el espectro». ${ }^{133}$

Pero la Corte fue más allá, notando que «bajo el mismo criterio en lo que respecta a la Primera Enmienda, los licenciatarios no están en mejor posición que aquellos a quienes se les negó la licencia». ${ }^{134}$ En consecuencia, el hecho de que la Primera Enmienda le permita al gobierno

\footnotetext{
I27. Red Lion Broad., Co. v. FCC (I969), 395 U.S. 367.

I28. Red Lion v. FCC, pág. 373.

I29. Red Lion v. FCC, pág. 375-77, 388.

I30. Red Lion v. FCC, pág. 388.

I3 I. Red Lion v. FCC, pág. 388.

I32. Red Lion v. FCC, pág. 389.

I33. Red Lion v. FCC, pág. 389.

I34. Red Lion v. FCC, pág. 389.
} 
negarle a alguien una licencia y asignársela a otro implica que la Primera Enmienda también le permite al gobierno exigirle al asignatario de la licencia que comparta su frecuencia con aquellos a quienes se les negó la licencia. Adicionalmente, esta interpretación le permitió al gobierno exigirle al titular de la licencia «conducirse como un intermediario o agente fiduciario, obligado a emitir aquellos puntos de vista y opiniones que representaran a su comunidad y que, de otra forma, estarían excluidos del espectro». ${ }^{135}$ En otras palabras, "debido a la escasez de frecuencias radioeléctricas, se autoriza al gobierno para restringir las licencias a favor de aquellos cuyos puntos de vista deben ser expresados por este especial único medio de expresión». ${ }^{136}$

Así, la escasez invierte la habitual prioridad de los valores de la Primera Enmienda. Cuando no existe una limitación física a la cantidad de gente que puede expresarse, como en el caso de los periódicos, el interés de los oradores es la máxima prioridad aun cuando éstos tengan un monopolio económico, y la cura para cualquier censura privada que pueda existir es más expresión, no regulación. La situación es distinta cuando las oportunidades para expresarse son escasas. La Corte señaló que «no hay un refugio en la Primera Enmienda para una censura privada ilimitada cuando opera en un medio que no está abierto a todos». ${ }^{137}$ En este caso, «la máxima prioridad es el derecho de los espectadores y radioyentes, y no el de las radioemisoras». ${ }^{138}$

Es relevante destacar que incluso el estándar menos proactivo de la

I35. Red Lion v. FCC, pág. 389. Cf. págs. 390-I: «En lugar de otorgar monopolios de frecuencia en un número relativamente pequeño de titulares de licencias... seguramente el gobierno podría haber decretado que cada frecuencia debería ser compartida entre todos o algunos de esos que desean usarla, siendo asignado cada uno una porción del día de transmisión o de la semana de transmisión... Como hemos dicho, la Primera Enmienda no confiere ningún derecho en los licenciados para prevenir que otros transmitan en «sus» frecuencias y ningún derecho a un monopolio incondicional de una escasez de recursos en la cual el gobierno ha denegado a otros el derecho a usarlo».

I36. Red Lion v. FCC, pág. 390.

I37. Red Lion v. FCC, pág. 392.

I3 8. Red Lion v. FCC, pág. 390. Cf. pág. 394: «El Congreso no tiene por qué quedarse de brazos cruzados y permitir que aquellos con licencias ignoren los problemas que rodean a la gente o excluir de las ondas todo menos sus propias visiones de las cuestiones fundamentales». 
Corte en Red Lion v. FCC no implicó que los intereses de libre expresión de los supuestos oradores necesariamente prevalecerían sobre los intereses de libre expresión de los intermediarios. Al contrario, los casos que aplican la doctrina de la escasez, como CBS v. DNC, resaltaron que el compensar entre el interés del público en contenidos equilibrados y el preservar el rol de las radioemisoras de ser un 'agente libre' periodístico implicaba un «delicado equilibrio entre intereses en conflicto» y demandaba de los reguladores el «caminar en 'la cuerda floja'» entre distintos valores de libre expresión en competencia. ${ }^{139}$

El resultado es que los casos de radioemisión de la Corte han tratado consistentemente ambos criterios como valores importantes que deben ser enfrentados en razón del otro. ${ }^{140}$ Si bien la implementación de la Corte del estándar constitucional apropiado ha sido menos que clara, ${ }^{141}$ todos los estándares potenciales reconocen implícitamente que la discreción editorial ejercida por los intermediarios se mantiene como una circunstancia relevante en el equilibrio de la libre expresión. También

I39. CBS v. DNC (I973), pág. II7. Véase también la pág. Io4 que señala que la regulación de radiodifusión plantea el «mayor dilema» de "cómo lograr un equilibrio adecuado entre el control público y el privado».

I 40. Véase, por ejemplo, FCC $v$. League, pág. 380 , donde se reconoce que la «libertad de defender la posición propia sin también presentar puntos de vista opuestos» debe ser balanceada con el interés gubernamental en «asegurar una cobertura balanceada y adecuada de los asuntos públicos». CBS v. FCC, pág. 396, reconoce que la regulación de la radiodifusión implica «los intereses de la Primera Enmienda de candidatos y votantes, así como también de radiodifusores» y que la Corte "nunca ha aprobado un derecho general de acceso a los medios» y podría a lo más sostener «un derecho limitado a acceso 'razonable'» (el primer énfasis es nuestro).

I4I. La Corte ha indicado claramente que el estándar es inferior a un escrutinio estricto, pero ha tenido dificultades para determinar con precisión qué estándar debe aplicarse. Por ejemplo, en FCC $v$. League la Corte empleó un lenguaje que recuerda el examen intermedio cuando sostuvo que las restricciones a la discreción editorial de los radiodifusores debe ser «estrictamente delimitada para promover un interés gubernamental sustancial» (FCC v. League, pág. 380). En otro caso, la Corte usó un lenguaje que recordaba más el estándar de base racional. Véase FCC v. Nat'l Citizens Comm. for Broad. (I 978), 436 U.S. 775, pág. 802, 803, donde se sostienen las regulaciones como un «medio razonable para promover el interés público» y como «una ponderación racional de las políticas de competencia»); en el mismo caso, en páginas 805, 808 n. 29, 8 I 4, 8I 5 , se concluye que la FCC no actuó de forma irracional. 
vale la pena destacar que la prioridad al otro lado de este equilibrio no es para el eventual orador que deseare usar una radioemisora como una plataforma para comunicar su discurso, sino para el auditor. Incluso este estándar más limitado de la Primera Enmienda no es compatible con el tipo de acceso irrestricto al canal, del tipo propuesto por quienes apoyan la ausencia de intermediación.

En el caso Red Lion v. FCC se consideró que la posibilidad de mejorar la capacidad de usar de forma más eficiente el espectro podría eliminar la escasez. ${ }^{142}$ Si bien la Corte finalmente concluyó que la demanda de frecuencias había superado el ritmo de mejoras tecnológicas, lo que mantenía la escasez del espectro, ${ }^{143}$ el hecho de que haya considerado la posibilidad parece sugerir que esta justificación, para desviarse del paradigma de la prensa, que prohibía cualquier violación de la discreción editorial de los periódicos, podría desaparecer en caso de que la escasez de espectro dejara de ser una limitación a la expresión radiotransmitida. De la misma forma, la Corte en CBS $v$. DNC pareció sugerir que los principios que regulan la normativa de radioemisión podrían cambiar al notar que «la industria de radioemisión es dinámica respecto del cambio tecnológico» y que «las soluciones que eran apropiadas hace una década ya no lo son necesariamente, y que las apropiadas hoy podrían ser anticuadas en Io años más». ${ }^{144}$ El voto concurrente del ministro Douglas a la sentencia igualmente señalaba que «la escasez podría prontamente ser una restricción del pasado, evitando así las disyuntivas de Red Lion v. FCC. Se ha predicho que en los próximos ro años será posible darle a los auditores más de 400 canales de televisión a través de los avances en la televisión por cable»..$^{145}$

La Corte explicitó este argumento en FCC $v$. League. La Corte inicialmente reconoció que la normativa diseñada para asegurar que «el público reciba una presentación equilibrada de información sobre asuntos de importancia pública $[. .$.$] nunca se ha permitido para los medios impresos». { }^{146}$

I42. Red Lion v. FCC, pág. 396-400.

I43. Red Lion v. FCC, pág. 400-I

I 44. $C B S$ v. DNC, pág. IO2.

I 45. CBS v. DNC, pág. I 58.

I46. FCC v. League, pág. 377, cita Miami Herald Publ'g Co. v. Tornillo (I974), 4I 8 U.S. $24 \mathrm{I}$. 
Al mismo tiempo, «las diferencias en las características de los nuevos medios justifican las diferencias en los estándares de la Primera Enmienda aplicables a ellos». ${ }^{147}$ Respecto a la radioemisión, la escasez del espectro electromagnético justifica el exigirle a las radioemisoras licenciadas el «servir de alguna forma como fideicomisarios del público al presentar esos puntos de vista y opiniones que representan a su comunidad y que, de otra forma, por necesidad, serían excluidas de estar al aire». ${ }^{148}$

En otras palabras, era la limitación a las oportunidades para expresarse lo que justificaba el restringir el ejercicio por las radioemisoras de su discreción editorial. El desarrollo posterior de la sentencia de la Corte esencialmente confirmó esta interpretación al reconocer que el hecho de que «la industria radioemisora operara derechamente bajo restricciones no impuestas a otros medios» era lo que justificaba el negarle a las radioemisoras «la libertad absoluta para promover sus exclusivos puntos de vista sin tener que presentar los puntos de vista opuestos» que sí tenían los periódicos. ${ }^{149} \mathrm{La}$ estructura de este argumento implicaba que la discreción editorial de las radioemisoras se beneficiaría nuevamente de la discreción editorial de los periódicos una vez que la escasez dejara de ser un problema.

En efecto, la Corte consideró precisamente esta posibilidad cuando señaló:

La justificación imperante para regular la radioemisión basada en la escasez del espectro ha sido progresivamente criticada en los últimos años. Los críticos, incluyendo al actual director de la FCC, postulan que con el advenimiento de las tecnologías de televisión por cable y satelital, las comunidades tendrán ahora acceso a una gama de estaciones tan amplia que la doctrina de la escasez se ha vuelto obsoleta. ${ }^{150}$

Sin embargo, la Corte no «estaba preparada para reconsiderar su enfoque de larga data sin una señal del Congreso o la FCC de que los desarrollos tecnológicos han avanzado tanto que se hace necesario revi-

I 47. FCC v. League, pág. 377, cita Red Lion v. FCC, pág. 386.

I48. FCC v. League, pág. 377, cita Red Lion v. FCC, pág.389.

I 49. FCC v. League, pág. 380.

I 50. FCC v. League, pág. 376, n. I I, cita a Fowler y Brenner (I982: 22 I-6). 
sar el sistema regulatorio para la radioemisión». ${ }^{151}$ De acuerdo con este razonamiento, si es que la tecnología finalmente llegara a un punto en que el espectro radioeléctrico dejara de ser escaso, el paradigma de la prensa se aplicaría nuevamente. Este razonamiento también implicaba que las restricciones a la discreción editorial no se aplicarían a ninguna tecnología futura en la medida en que no sufriera de escasez.

$\mathrm{He}$ analizado las deficiencias analíticas de la doctrina de la escasez en detalle en otros textos y no repetiré acá mis críticas (Yoo, 2003: 26769). Cualquiera que sea la continua validez de la doctrina de la escasez respecto de la radioemisión, ${ }^{152}$ la decisión clave de la Corte Suprema en Reno $v$. ACLU cerró firmemente la puerta a la posibilidad de aplicar esa doctrina a Internet. ${ }^{153}$ La Corte razonó que debido a que Internet «provee una capacidad de comunicación de todo tipo prácticamente ilimitada y a bajo costo [...] difícilmente puede considerarse como un commodity expresivo 'escaso'». ${ }^{154}$ Como consecuencia de ello, la Corte concluyó derechamente que «nuestra casuística no da fundamentos para determinar el nivel de escrutinio bajo la Primera Enmienda que debe aplicarse a este medio". .55

I 5 I. FCC v. League, pág. 377, n. I I. Podría decirse que la FCC proveyó dicha señal cuando se derogó la Doctrina de Equidad en I987. Véase Complaint of Syracuse Peace Council Against Television Station WTVH Syracuse, New York, Memorandum Opinion and Order, 2 F.C.C.R. 5043 (I987), aff'd, 867 F.2d 654 (D.C. Cir. I989). A pesar de ello, la Corte no obstante reafirmó la doctrina de la escasez cuando tuvo una próxima oportunidad para revisarla. Véase Metro Broad., Inc. v. FCC (I990), 497 U.S. 547, pág. 566-7. Un mejor resultado se explica por la manera en la que la jurisprudencia sobre radiodifusión de la Corte se enredó en la política judicial que rodea a la acción afirmativa. Véase Yoo (2003: 286-8).

I 52. Véase FCC v. Fox Television Stations (2009), I29 S. Ct. I800, págs. I 820-2, J. Thomas, voto concurrente, llamó a la anulación de la doctrina de la escasez. Turner v. FCC, pág. 638 , señaló la crítica de la doctrina de la escasez en lo que respecta a la radiodifusión.

I 53. Reno v. ACLU, pág. 870.

I 54. Reno v. ACLU, pág. 870.

I 55. Reno $v$. ACLU, pág. 870. Algunos expertos han intentado reconstruir esta base lógica, cambiando el enfoque desde la escasez del espectro a la escasez de atención. Sobre la base del conocimiento de Herbert Simon de que «una riqueza de información crea pobreza de atención» (I97I: 40), estos expertos sostienen que la sobrecarga de información se convierte en una justificación para limitar la capacidad de los motores de búsqueda 
Luego de una declaración tan amplia sobre la inaplicabilidad de la doctrina de la escasez respecto de Internet, cuesta ver cómo podría servir de justificación para invalidar el ejercicio de los intermediarios en Internet de su discreción editorial. En ausencia de dicha justificación por escasez, el estándar por defecto debe ser el de los periódicos, en que predomina la discreción editorial de los intermediarios.

\section{FCC V. PACÍFICA: INVASIVIDAD Y ACCESIBILIDAD COMO JUSTIFICACIÓN PARA LIMITAR LA DISCRECIÓN EDITORIAL}

En FCC v. Pacifica Foundation (en adelante, «FCC v. Pacífica»), ${ }^{156}$ la Corte Suprema estadounidense nuevamente reafirmó que el paradigma para la prensa representaba la base relevante al reiterar que «la Primera Enmienda protege a los editores de periódicos de la posibilidad de exigirles que publiquen las réplicas de aquellos a quienes critican». ${ }^{157}$ No obstante, la radiodifusión no gozaba de dicha protección. ${ }^{158}$ En vez de invocar la doctrina de la escasez, la Corte desarrolló dos nuevos argumentos para otorgar un menor grado de protección bajo la Primera Enmienda a la radiodifusión: «Primero, los medios de radiodifusión han establecido una presencia penetrante única en las vidas de los todos los americanos» con su capacidad de "confrontar al ciudadano... en la privacidad de su hogar». ${ }^{159}$ «Segundo, la radiodifusión es especialmente accesible para los niños, incluso aquellos demasiado jóvenes para leer». ${ }^{160}$ Cabe mencionar

para intermediar la expresión. Véase Bracha y Pasquale (2008: I I 5 8), Chandler (2007: I 104) y Elkin-Koren (200I: I 83-84). Este argumento es curioso por un número de razones. Como cuestión inicial, en el intento de reformular la abundancia como escasez, subvirtió a la escasez por completo. Por otra parte, un mundo de abundancia aumenta, no disminuye, la necesidad de fuertes ejercicios de discreción editorial. Por último, ya que la atención es inherentemente limitada, si se acepta, tal razonamiento no admitiría ningún principio limitante y daría lugar a la regulación endémica de cada aspecto de las interacciones en línea de un individuo.

I 56. FCC v. Pacifica Found. (1978), 438 U.S. 726.

I 57. FCC v. Pacifica Found., pág. 748, cita Miami Herald Publ'g Co. v. Tornillo, pág. 258.

I 5. FCC v. Pacifica Found., pág. 748, cita Red Lion v. FCC, pág. 377-8.

I 59. FCC v. Pacifica Found., pág. 748, cita Rowan v. U.S. Post Office Dep’t (I970), 397 U.S. 728, pág. 736-7.

160. FCC v. Pacifica Found., pág. 749. 
que en FCC $v$. Pacífica se utiliza el estándar de los periódicos como base, por tanto, si sus argumentos fallan, vuelve a primar la discreción editorial asociada a ellos. ${ }^{161}$

He descrito en otros documentos las deficiencias analíticas de estos argumentos (Yoo, 2003: 292-303). En efecto, existen algunas señales de que la Corte Suprema podría estar lista para revocar FCC v. Pacifica. ${ }^{162}$ No obstante su eventual supervivencia en lo relacionado con la radiodifusión, la decisión de la Corte en Reno $v$. ACLU derechamente precluyó cualquier posibilidad de que los argumentos de FCC $v$. Pacífica puedan utilizarse respecto de Internet. Como apuntó la Corte, «Internet no es tan 'invasiva' como la radio o la televisión. La Corte de Distrito concluyó específicamente que las 'comunicaciones por Internet no invaden el hogar del individuo o aparecen en la pantalla de forma no solicitada. Raramente los usuarios encuentran contenidos por accidente'». ${ }^{163} \mathrm{La}$ Corte adicionalmente recordó que había rechazado un argumento similar en Sable Communications of California, Inc. v. FCC (en adelante, «Sable v. FCC»), ${ }^{164}$ en el cual el gobierno había citado FCC v. Pacífica para justificar una prohibición reglamentaria de mensajes dial-a-porn indecentes. ${ }^{165}$ La Corte en Reno v. ACLU observó que Sable v. FCC se diferenciaba del fallo «claramente limitado» de FCC $v$. Pacífica al notar que «el teléfono por discado que el oyente siga pasos activos para recibir la comunicación» y enfatizando que contenidos objetables son normalmente precedidos por advertencias, las que hacen menos posible que el receptor pueda ser sorprendido. ${ }^{166}$

La Corte adicionalmente concluyó que, a menos que pudieren aplicarse los argumentos de FCC v. Pacífica, toda restricción debe ser estrecha-

I6r. FCC v. Pacifica Found., pág. 748.

I62. Véase FCC v. Fox Television Stations (2009), I29 S. Ct. I800, pág. I8 I9, que reenvía a la corte de apelaciones una impugnación a la decisión de la FCC de abandonar su política de «improperios fugaces», mientras señala que la constitucionalidad de las restricciones de indecencia del tipo confirmado por Pacifica «serán determinadas pronto, quizás en este mismo caso». FCC v. Fox Television Stations, págs. I8I9-22, J. Thomas, voto concurrente, pidió que Pacifica sea anulada.

I63. Reno v. ACLU, pág. 869, cita ACLU v. Reno (I996), 929 F. Supp. 824, pág. 844.

I64. Sable Commc'ns of Cal., Inc. v. FCC (1989), 492 U.S. I I 5.

I65. Reno v. ACLU, pág. 869, cita Sable, 492 U.S., pág. I26.

I66. Reno v. ACLU, pág. 870, cita Sable, 492 U.S., págs. I27-8. 
mente ajustada respecto del daño, si ha de sobrevivir su control de constitucionalidad. ${ }^{167} \mathrm{La}$ existencia de software que permite a los padres filtrar contenidos indeseados invalidó toda pretensión de que la prohibición fuese adoptada de forma limitada. ${ }^{168}$ En un mundo así, la preocupación por la invasividad y accesibilidad parecen especialmente fuera de lugar.

Luego de tan categórico rechazo, es difícil ver como FCC v. Pacífica podría servir como base para mantener a Internet en la categoría más inferior de control bajo la Primera Enmienda. Los razonamientos de FCC v. Pacífica sugieren que Internet estará regida por la protección asociada a los periódicos, bajo la cual prima la discreción editorial de los intermediarios.

Por lo tanto, los precedentes para la radiodifusión fracasan en otorgar un fundamento para invalidar la discreción editorial ejercida por los intermediarios de Internet. Estos precedentes van más allá de simplemente reconocer que el ejercicio de discreción editorial por los intermediarios promueve importantes valores de libre expresión que deben ser protegidos. Dado que la Corte Suprema ya ha sostenido la no aplicabilidad de los estándares más relajados para la radiodifusión a Internet en ambas líneas de precedentes, los precedentes para radiodifusión implican que el ejercicio de discreción editorial por los intermediarios de Internet debe recibir el mismo nivel de protección que el de los periódicos. Aplicando armónicamente esta interpretación, las sentencias posteriores de la Corte han evaluado restricciones a la expresión en Internet bajo el supuesto de que Internet goza de la más completa protección bajo la Primera Enmienda. ${ }^{169}$ Los precedentes sobre radiodifusión de la Corte Suprema deben en

I67. Véase Reno $v$. ACLU, págs. 879, 882, que falla que las restricciones impuestas por la Communications Decency Act de 1996 no pasaron el filtro constitucional, ya que no eran estrictamente limitadas.

I68. Reno v. ACLU, pág. 877; cf. Sable, 492 U.S., págs. I30-I, que señala que debido a las restricciones tecnológicas en los mensajes dial-a-porn eran adecuadas para prevenir que la mayoría de los niños los escucharan, la prohibición total de mensajes telefónicos obscenos no estaba estrictamente limitada.

I69. Véase Ashcroft v. ACLU (2004), 542 U.S. 656, pág. 666, concluye que una regulación en la libertad de expresión en Internet podría sobrevivir sólo si constituye «el medio menos restrictivo disponible». Ashcroft v. ACLU (2002), 535 U.S. 564, pág. 580 , sostiene que las regulaciones de la libertad de expresión en Internet deben ser «suficientemente estrictas» para poder pasar el escrutinio de la Primera Enmienda. 
consecuencia aplicarse como base de un fuerte apoyo a la importancia de preservar la discreción editorial de los intermediarios. Cualquier restricción de dicha discreción inhibiría importantes valores expresivos.

\section{LA IMPORTANCIA Y LOS LÍMITES DE LA DISCRECIÓN EDITORIAL EJERCIDA POR LOS CABLEOPERADORES}

La importancia de preservar la discreción editorial de los intermediarios está además apoyada por las sentencias de la Corte Suprema respecto del otro gran medio de comunicación electrónica: la televisión por cable. Al igual que los precedentes de la Corte respecto a los periódicos y las radioemisoras, estas sentencias sostienen y confirman que las decisiones de los cableoperadores respecto a qué contenidos transmitir representan un importante ejercicio de la libertad de expresión. Esta discreción editorial opera incluso si el cableoperador sirve sencillamente como un conducto para la expresión de terceros o usa su discreción a favor de un punto de vista particular. En efecto, la capacidad para favorecer puntos de vista particulares constituye la esencia misma de la discreción editorial, y dicha capacidad no puede ser restringida sin inhibir los beneficios para la libertad de expresión provistos por la discreción editorial. ${ }^{170}$

Turner $v$. FCC sí sostuvo que algunas restricciones a la discreción editorial de un cableoperador podían justificarse si éste ejerce un control exclusivo sobre un cuello de botella físico crítico. ${ }^{171}$ Sin embargo, el reconocimiento judicial de las diversas opciones existentes para recibir servicios de Internet hace que sea muy poco probable que este razonamiento pudiera justificar mantener semejantes restricciones sobre Internet.

\section{LA IMPORTANCIA DE LA DISCRECIÓN EDITORIAL DE LOS CABLEOPERADORES}

Las decisiones de la Corte Suprema respecto a la televisión por cable han enfatizado largamente la importancia de preservar la discreción editorial de los cableoperadores. La Corte se pronunció sobre este asunto por primera vez en FCC $v$. Midwest Video Corp. (en adelante, «FCC $v$.

I70. Para un argumento contrario, véase Nadel (I987).

I7I. Turner v. FCC, págs. 656-7. 
Midwest»), ${ }^{172}$ al rechazar el intento de la FCC de imponerle a los cableoperadores lo que en la práctica constituía una exigencia de common carriage. ${ }^{173}$ La primera justificación de la Corte para revocar la regulación era estatutaria. La ausencia de un reglamento que le otorgara explícitamente a la FCC jurisdicción sobre la televisión por cable significó que toda potestad regulatoria que poseía se derivaba necesariamente de su impacto subsidiario sobre la radioemisión. Dado que la jurisdicción de la FCC sobre el cable derivaba completamente de su jurisdicción sobre la radioemisión, toda limitación estatutaria a sus potestades para regular la radioemisión era necesaria e igualmente aplicable a su potestad para regular la televisión por cable. ${ }^{174}$

Respecto a las regulaciones objeto de la controversia, en FCC $v$. Midwest la limitación más importante a la jurisdicción de la FCC sobre la radioemisión era una disposición reglamentaria que le impedía tratar a los radioemisores como common carriers, como se desprendía de la historia legislativa analizada en CBS v. DNC. ${ }^{175}$ Por lo tanto, al evaluar la legalidad de que la FCC intentara imponerle obligaciones de common carriage a los cableoperadores, la Corte no pudo «ignorar el severo rechazo del Congreso... de negar la discreción editorial que de otra forma disfrutan tanto los radioemisores como los cableoperadores». ${ }^{176} \mathrm{El}$ hecho de que «el Congreso haya restringido la potestad de la FCC para profundizar en los fines asociados al acceso público en desmedro de la libertad periodística de las personas que trabajan en la radioemisión» implicaba que la FCC tampoco tenía autoridad para imponer restricciones similares a la libertad periodística de las personas que proveen servicios de televisión por cable. ${ }^{177}$

La Corte también invocó razones de política pública, concluyendo que las consideraciones sobre libertad de expresión que justificaban proteger la discreción editorial de los radioemisores también eran aplicables a los cableoperadores. La Corte concluyó que el rechazo del Congreso a

\footnotetext{
I72. FCC v. Midwest Video Corp. (I979), 440 U.S. 689.

I73. FCC v. Midwest, págs. 708-9.

I74. FCC v. Midwest, págs. 706-8.

I75. FCC v. Midwest, págs. 702-4, cita CBS v. DNC, págs. I05-9.

176. FCC $v$. Midwest, págs. 708.

I77. FCC v. Midwest, págs. 707.
} 
restringir la libertad periodística que hubiera significado tratarlos como common carriers no era una limitación «aplicable en particular a la emisión televisiva. Su fuerza no se ve disminuida por la tecnología derivada usada en las transmisiones por cable. Los cableoperadores ahora comparten con los radioemisores una cantidad significativa de discreción editorial respecto a lo que incluirá su programación». ${ }^{178} \mathrm{Al}$ fallar de esa forma, la Corte rechazó las pretensiones de que la restricción a discreción editorial de los cableoperadores era insignificante, aunque la Corte omitió pronunciarse sobre si «la discreción ejercida por los cableoperadores es de la misma magnitud que aquella que gozan los radioemisoras». ${ }^{179}$ Incluso si la restricción no desplazaba una programación alternativa, «el obligar de forma indiscriminada a los cableoperadores a aceptar programación de acceso público interferiría con sus decisiones respecto a la totalidad de la oferta de servicio otorgada a sus suscriptores». ${ }^{180}$ Debido a que la Corte resolvió el caso basándose en fundamentos estatutarios, no se pronunció sobre la decisión del tribunal inferior de que una restricción de common carriage violaba la Primera Enmienda, «excepto para reconocer que [la pregunta] no es superficial». ${ }^{181}$

La sentencia de la Corte en Los Angeles v. Preferred Communications, Inc. (en adelante, "Los Angeles v. Preferred» ${ }^{182}$ reconoció aún más la importancia de la discreción editorial ejercida por los cableoperadores. En este caso, un cableoperador alegó que la denegación de una ciudad de otorgarle una concesión de televisión por cable violaba su derecho a la libertad de expresión. ${ }^{183}$ El tribunal de primera instancia había rechazado el argumento del cableoperador basado en la Primera Enmienda por no acreditar legitimación activa, sólo para ver a la Corte Suprema revocar dicha sentencia. ${ }^{184}$ La Corte falló explícitamente que «las actividades en que [el cableoperador] desea participar claramente implican intereses sobre la Primera Enmienda». ${ }^{185} \mathrm{Al}$ fallar

\footnotetext{
I 78. FCC $v$. Midwest, págs. 707.

I79. FCC $v$. Midwest, págs. 707, n. I7.

I 80. FCC v. Midwest, págs. 707, n. I7.

I8I. FCC v. Midwest, págs. 709, n. I9.

I 82. City of Los Angeles v. Preferred Commc'ns, Inc. (I986), 476 U.S. 488.

I 83. City of Los Angeles v. Preferred Commc'ns, Inc., págs. 49 I-2.

I 84. City of Los Angeles v. Preferred Commc'ns, Inc., pág. 492.

I 85. City of Los Angeles v. Preferred Commc'ns, Inc., pág. 494.
} 
de esa forma, la Corte citó en señal de aprobación la aseveración del cableoperador:

el negocio de la televisión por cable, como el de los periódicos y las revistas, es otorgarle a sus suscriptores una mezcla de noticias, información y entretención. Tal como lo hacen los periódicos, la empresas de televisión por cable usan una parte de su espacio disponible para reimprimir (o retransmitir) las comunicaciones de terceros, al mismo tiempo que proveen contenidos originales. ${ }^{186}$

Así, la Corte concluyó que «ya sea a través de su programación original o ejerciendo su discreción editorial respecto a qué estaciones o programas incluir en su repertorio, [un cableoperador] busca transmitir mensajes sobre una amplia gama de temas en una amplia variedad de formatos». ${ }^{187}$

La Corte también reafirmó su reconocimiento en FCC $v$. Midwest de que «los cableoperadores ejercen una cantidad significativa de discreción editorial respecto a qué programación incluir». ${ }^{188}$ La Corte argumentó:

La televisión por cable participa de algunos de los aspectos expresivos y de difusión de ideas como lo hacen los negocios tradicionales de prensa y editoriales de libros, oradores públicos y panfletistas. Las eventuales actividades del demandado implicarían intereses sobre la Primera Enmienda al igual que las actividades de las emisoras inalámbricas, las que se concluyó caen dentro de la esfera de la Primera Enmienda.... ${ }^{189}$

Así, en Los Angeles v. Preferred quedó claramente establecido que la expresión de los cableoperadores involucra a la Primera Enmienda. A mayor abundamiento, el reconocimiento de la Corte de que los cableoperadores promueven la libertad de expresión no sólo cuando producen contenidos originales, sino también cuando «usan una porción de su espacio disponible para reimprimir (o retransmitir) las comunicaciones de terceros», confirma que promueven la libre expresión incluso cuando sencillamente actúan como conducto para la expresión de terceros. ${ }^{190}$

I86. City of Los Angeles v. Preferred Commc'ns, Inc., pág. 494.

I87. City of Los Angeles v. Preferred Commc'ns, Inc., pág. 494.

I88. City of Los Angeles v. Preferred Commc'ns, Inc., pág. 494, cita FCC v. Midwest, pág. 707.

189. City of Los Angeles v. Preferred Commc'ns, Inc., págs. 494-5.

I90. City of Los Angeles v. Preferred Commc'ns, Inc., pág. 494. 
La Corte reafirmó en Leathers v. Medlock, ${ }^{191}$ que el ejercicio de su discreción editorial por los cableoperadores promueve importantes valores de libre expresión. En ese caso, la Corte sentenció que «la televisión por cable provee a sus suscriptores de noticias, información y entretención. Está involucrada en 'expresión’ bajo la Primera Enmienda y es, en una gran parte de su operación, parte de la 'prensa'». ${ }^{192}$

La Corte también apoyó esta conclusión en Turner v. FCC. ${ }^{193}$ En ese caso, la Corte señaló categóricamente que «no puede haber desacuerdo» sobre la «premisa inicial» de que los programadores de cable y los cableoperadores ejercen y transmiten expresión, y que tienen derecho a beneficiarse de la protecciones otorgadas por las cláusulas de la Primera Enmienda sobre libertad de expresión y prensa. ${ }^{194}$ En efecto, así funciona sin importar si el cableoperador ofrece «programación original» o si sencillamente «ejerce su discreción editorial respecto a qué estaciones o programas incluir en su parrilla». ${ }^{195} \mathrm{Al}$ fallar así, la Corte concluyó que «el fundamento de aplicar un estándar de análisis menos riguroso en función de la Primera Enmienda a la regulación de radiotransmisión, no obstante su aplicabilidad al caso particular, no es aplicable en el contexto de la regulación de la televisión por cable». ${ }^{196}$

Luego de resaltar la crítica judicial y académica a la doctrina de la escasez, ${ }^{197}$ la Corte concluyó que el hecho de que «la televisión por cable no sufra las limitaciones inherentes que caracterizan a los medios radioemitidos» y la falta de «cualquier peligro de interferencia física entre dos cableoperadores que intentan utilizar el mismo canal» hacen inaplicable la doctrina de la escasez. ${ }^{198}$ En consecuencia, la Corte resolvió que «la aplicación del estándar de análisis más relajado adoptado en Red Lion v. FCC y en los otros casos de radioemisión no es apto al determinar la validez bajo la Primera Enmienda de la regulación del cable». ${ }^{199}$

\footnotetext{
I9I. Leathers v. Medlock (I99I), 499 U.S. 439, pág. 444.

I92. Leathers $v$. Medlock (I99I), 499 U.S. 439, pág. 444.

193. Turner v. FCC, pág. 636.

I94. Turner v. FCC, pág. 636, cita Leathers, 499 U.S., pág. 444.

I95. Turner v. FCC, pág. 636, cita Preferred Commc’ns, 476 U.S., pág. 494.

I96. Turner v. FCC, pág. 637.

197. Turner v. FCC, pág. 638.

I98. Turner v. FCC, pág. 639.

199. Turner v. FCC, pág. 639.
} 
La Corte nuevamente trató el tema de los valores de libre expresión promovidos por la discreción editorial de los cableoperadores en Denver Area Educational Telecommunications Consortium v. FCC. ${ }^{200}$ Si bien la sentencia contenía un gran número de decisiones seriamente divergentes, la Corte confirmó por unanimidad el positivo rol que la discreción editorial de los cableoperadores tiene en promover la libre expresión.

Por ejemplo, la opinión de mayoría relativa ${ }^{201}$ redactada por el ministro Breyer, la que fue compartida en sus partes esenciales por los ministros Stevens, O’Connor y Souter, empezaba notando que los canales del cable juegan una amplia gama de roles, incluyendo el servir como conducto para la expresión de terceros, proveyendo programación original y retransmitiendo señales de libre recepción. ${ }^{202}$ La pluralidad reiteró el reconocimiento de la Corte en Turner v. FCC de que «la función editorial es en sí misma un aspecto expresivo» y la decisión de un tribunal de que un privado, por ejemplo, el dueño de una estación, sea un «censurador», podría en sí interferir con la libertad de ese «censurador» privado de expresarse como editor. ${ }^{203}$ Cualquier intento de enfocarse solamente en los intereses de aquellos que usarían el cable como un conducto para su expresión ignora el «legítimo rol» ejercido por «los intereses expresivos de los cableoperadores». ${ }^{204}$

El ministro Kennedy, junto con la ministra Ginsburg, tocaron temas similares, notando que «los cableoperadores obviamente tienen derechos bajo la Primera Enmienda» y que «las actividades de un cableoperador creando programación original o ejerciendo su discreción editorial respecto de los programas provistos por terceros en su sistema... están protegidas». ${ }^{205}$ El ministro Kennedy hizo una distinción entre el acceso licitado, que regula a los canales respecto de los cuales los cableoperadores han ejercido históricamente su discreción, y el acceso público, que regula a los canales respecto de los cuales los cableoperadores nunca

200. Denver Area Educ. Telecomms. Consortium, Inc. v. FCC (I996), 5 I 8 U.S. 727.

20I. "Plurality opinion» en el original en inglés.

202. Denver Area Educ. Telecomms. Consortium, Inc. v. FCC, págs. 733-4 (voto de mayoría).

203. Denver Area Educ. Telecomms. Consortium, Inc. v. FCC, págs. 737-8, cita Turner v. FCC, pág. 636.

204. Denver Area Educ. Telecomms. Consortium, Inc. v. FCC, pág. 747.

205. Denver Area Educ. Telecomms. Consortium, Inc. v. FCC, pág. 792,. 
han ejercido control, y concluyeron que las leyes que regulan las primeras son más problemáticas que aquellas que regulan a las últimas. ${ }^{206} \mathrm{El}$ efectuar esta distinción el ministro Kennedy reforzó el importante rol que la discreción editorial juega en la promoción de la libre expresión en aquellas áreas en que existe discreción editorial.

El ministro Thomas, junto con el presidente Rehnquist y el ministro Scalia, tomaron una postura aún más expansiva de los derechos de los cableoperadores bajo la Primera Enmienda. Como notó el ministro Thomas, los precedentes de la Corte Suprema habían reconocido por mucho tiempo que los cableoperadores se expresan tanto cuando crean programación como cuando ejercen discreción editorial sobre qué estaciones incluir en su parrilla. ${ }^{207}$ Si bien existía una ambigüedad considerable respecto a si la discreción editorial de los cableoperadores «tendría derecho a las sustanciales protecciones de la Primera Enmienda conferidas a los medios impresos» o si estaría sujeta a menores protecciones otorgadas a la radioemisión, la Corte clarificó que «con el paso del tiempo... se ha acercado más a reconocer que los cableoperadores deberían gozar de los mismos derechos bajo la Primera Enmienda que los medios tradicionales». ${ }^{208}$ De hecho, a pesar de los desacuerdos en Turner $v$. FCC respecto a si las reglas de must-carry están basadas en contenido, el ministro Thomas concluyó que «existe acuerdo de que en general los cableoperadores tiene derecho a la misma protección bajo la Primera Enmienda que los medios impresos».209

El ministro Thomas además argumentó que el acoger el paradigma de la prensa significaba extenderle el más alto nivel de protección bajo la Primera Enmienda al ejercicio por los cableoperadores de su discreción editorial. Luego de Turner v. FCC, la declaración de la Corte en Red Lion v. FCC de que los intereses de la audiencia son soberanos «no pue-

206. Denver Area Educ. Telecomms. Consortium, Inc. v. FCC, págs. 793, 796.

207. Denver Area Educ. Telecomms. Consortium, Inc. v. FCC, pág. 8I4-5, J. Thomas, concurrió en la sentencia en parte y disidente en parte. Cita City of Los Angeles v. Preferred Commc'ns, Inc. (I986), 476 U.S. 488, pág. 494; Leathers v. Medlock (I99I), 499 U.S. 439, pág. 444 .

208. Denver Area Educ. Telecomms. Consortium, Inc. v. FCC, pág. 8I3-4.

209. Denver Area Educ. Telecomms. Consortium, Inc. v. FCC, pág. 8I 5; cf. pág. 8I6, donde se señala que Turner $v$. FCC «adoptó gran parte del paradigma de la prensa impresa» y «rechazó Red Lion» para el cable. 
de dársele crédito en el contexto del cable. Es el derecho del cableoperador el preeminente». ${ }^{210}$ Bajo el estándar de la prensa, "cuando existe un conflicto, el derecho declarado del programador de transmitir sobre el sistema de un cableoperador debe ceder ante la discreción editorial de dicho operador». ${ }^{211}$ En efecto, Turner v. FCC involucraba a la Primera Enmienda porque las reglas de must-carry «interfirieron con la discreción editorial de los cableoperadores al obligarlos a transmitir programación que de otra forma no transmitirían». ${ }^{212}$ La Corte «reconoció implícitamente [en Turner $v$. FCC] que el derecho de un programador a competir en un espacio de transmisión se deriva de, y está subordinado a, la discreción editorial del cableoperador» y que los programadores «no tienen un derecho independiente bajo la Primera Enmienda para que su programación sea transmitida».213 Al alcanzar llegar a esta conclusión, la Corte en Turner v. FCC «reconoció la primacía general de la derechos editoriales del cableoperador sobre los derechos de los programadores y de la audiencia». ${ }^{214}$ Por lo tanto, «son los derechos del cableoperador, y no los del programador de acceso, los que se han infringido». ${ }^{215} \mathrm{El}$ resultado es que el ministro Thomas acogió una "presunción constitucional... a favor de la discreción editorial de los cableroperadores» y rechazó una presunción constitucional a favor de cualquier derecho de los programadores para expresarse en los canales de pago. ${ }^{216}$

Las distintas posiciones adoptadas por las diversas opiniones en el caso Denver no son fácilmente resumibles. Si bien los ministros no estuvieron de acuerdo respecto al nivel de revisión apropiado que debía aplicarse y sobre la constitucionalidad de varias disposiciones, la Corte fue unánime en concluir que la discreción editorial ejercida por los cableoperadores promueve importantes valores de libre expresión. Estos valores son aplicables incluso cuando los cableroperadores sencillamente sirven como conducto para la expresión de terceros. El hecho de que

2 го. Denver Area Educ. Telecomms. Consortium, Inc. v. FCC, pág. 8I6. 2I I. Denver Area Educ. Telecomms. Consortium, Inc. v. FCC, pág. 8I6. 2I 2. Denver Area Educ. Telecomms. Consortium, Inc. v. FCC, pág. 8I6. 2I3. Denver Area Educ. Telecomms. Consortium, Inc. v. FCC, pág. 8I6-7. 214. Denver Area Educ. Telecomms. Consortium, Inc. v. FCC, pág. 8I7. 21 5. Denver Area Educ. Telecomms. Consortium, Inc. v. FCC, pág. 824 . 2 16. Denver Area Educ. Telecomms. Consortium, Inc. v. FCC, pág. 822. 
los cableoperadores puedan favorecer cierta expresión por sobre otra no es un problema potencial que deba remediarse. Al contrario, dicho favoritismo es inherente al cualquier ejercicio de discreción editorial. Así, cualquier límite regulatorio impuesto a la discreción editorial de los cableoperadores podría prevenir el ejercicio de estos importantes valores de libre expresión.

\section{TURNER V. FCC: EL CONTROL DEL ACCESO COMO JUSTIFICACIÓN PARA LIMITAR LA DISCRECIÓN EDITORIAL}

Así, los casos sobre televisión por cable de la Corte Suprema reconocieron que la discreción editorial de los cableoperadores promueve importantes valores de libre expresión. Adicionalmente, Turner v. FCC derechamente precluyó cualquier posibilidad de que la doctrina de la escasez usada para justificar restricciones a la discreción editorial de las radioemisoras pudiera aplicarse al cable.

Al mismo tiempo, Turner $v$. FCC ofreció tres razones para rechazar la aplicación al cable del estándar para la prensa escrita desarrollado en el caso Tornillo. Las primeras dos eran principios generales que se aplicarían a todas las formas de expresión y por lo tanto eran inútiles para distinguir las comunicaciones transmitidas vía televisión por cable de otras formas de comunicaciones. ${ }^{217}$ La tercera razón se enfocó en «la importante diferencia tecnológica entre los periódicos y la televisión por cable». ${ }^{218}$ Específicamente, la Corte notó que «si bien tanto un periódico como un cableoperador gozan de un estatus monopólico en una localidad específica, el cableoperador ejerce un control aun mayor respecto al acceso al medio relevante». ${ }^{219}$ Incluso si un periódico es un monopolio natural, no «posee el poder de obstruir el acceso de sus lectores a otras publicaciones que le compiten» y no puede "prevenir que otros

2I7. La primera razón fue que las restricciones en cuestión «no son activadas por cualquier mensaje particular emitido por operadores de cable y por lo tanto no hay sanción exacta basada en el contenido». La segunda razón fue que la corte no pensó que la regulación podría «forzar a los operadores de cable a alterar sus propios mensajes para responder a la programación de emisión que ellos son requeridos de llevar adelante». Turner v. FCC, pág. 655.

218. Turner v. FCC, pág. 656.

219. Turner v. FCC, pág. 656. 
periódicos se distribuyan en la misma localidad entre quienes lo reciben voluntariamente».220

Sin embargo, la Corte concluyó que «ello no es igualmente cierto para el cable». ${ }^{221}$ En cambio, "cuando una persona se suscribe al cable, la conexión física entre la televisión y la red de cable le otorga al cableoperador un control tipo cuello de botella, o de portero, sobre casi toda (si no toda) la programación televisiva que recibe el hogar del suscriptor».222 En consecuencia, «la propiedad de los cableoperadores del conducto esencial para la expresión en el cable» les otorga un poder para «silenciar, con solo pulsar un botón, la voz de quienes compiten por expresarse». ${ }^{223}$ Este "control físico de un conducto crítico de comunicación» crea «la posibilidad para abusar del... poder privado sobre un canal central de comunicación» suficiente para justificar un mayor control sobre la discreción editorial de los cableoperadores que la que se permitiría a los periódicos».224

Hay varios aspectos de la sentencia de la Corte que vale la pena resaltar. En primer lugar, es aleccionador el que la Corte haya tomado el paradigma de la prensa como el punto basal aplicable. Ello implica que, a menos que se acrediten fundamentos para desviarse del estándar, tanto la televisión por cable como otros medios deben disfrutar de las mismas protecciones bajo la Primera Enmienda que tienen los periódicos. En segundo lugar, la Corte rechazó específicamente el argumento de que el que una tecnología en particular sea un monopolio económico justifique otorgarle una menor protección bajo la Primera Enmienda. En cambio, es sólo el riesgo de censura privada por el control que los cableoperadores mantienen sobre una conexión física exclusiva, el fundamento suficiente para el justificar la anulación del ejercicio por los cableoperadores de su discreción editorial. De no ser así, el caso Tornillo habría sido fallado erróneamente, y el gobierno podría imponer exigencias de acceso a cualquiera que tenga una posición económica dominante, sin violar la Primera Enmienda.

220. Turner v. FCC, pág. 656.

221. Turner v. FCC, pág. 656.

222. Turner v. FCC, pág. 656 (el énfasis es nuestro).

223. Turner v. FCC, pág. 656.

224. Turner v. FCC, pág. 657. 
Cualquiera que sea la validez continua del argumento de los cuellos de botella respecto a la televisión por cable, ${ }^{225}$ es prácticamente seguro que no es aplicable a Internet. ${ }^{226}$ En la última década, las empresas de cable y telefonía han mantenido una activa competencia para instalar tecnologías de cable-módem y de líneas de abonado digital. Si bien los proveedores de cable-módem establecieron y mantuvieron una ventaja temprana sobre las DSL, recientemente han sido las empresas de telefonía las que han instalando tecnologías más avanzadas, como la red de fibra óptica FiOS de Verizon, y la red basada en VDSL U-verse de AT\&T, han hecho posible otorgar velocidades de banda ancha que sobrepasan aquellas permitidas por la arquitectura de cable-módem actual (Spulber y Yoo, 2008: 7-9). Esta competencia resultante a su vez ha forzado a la industria del cable a mejorar su infraestructura instalando una nueva tecnología conocida como DOCSIS 3.0, la que permite soportar velocidades incluso mayores (Kumar, 2008).

Pero quizás el cambio más importante, usualmente pasado por alto en el ambiente competitivo de los últimos años, es el advenimiento de los servicios inalámbricos móviles. Éstos han tenido un crecimiento espectacular. Medido en términos de «líneas de servicios avanzados» (definidos como servicios capaces de soportar velocidades de carga y descarga superiores a $200 \mathrm{kbps}$ ), los servicios inalámbricos móviles partieron no teniendo suscriptores al principio de 2005 , a llegar a tener I4,5 millones de suscriptores y aproximadamente el $17 \%$ del mercado hacia fines del $2008 .^{227}$ El éxito de la banda ancha móvil se torna aún más dramática si se mide en términos de «líneas de alta velocidad» (definidas como servicios capaces de soportar velocidades superiores a $200 \mathrm{kbps}$ en por lo menos una dirección). En el mismo período de tiempo, la banda ancha móvil ha capturado casi 25 millones de suscriptores, lo que representa

225. Yoo (2005: 722) discute cómo la similaridad funcional entre el cable y el directbroadcast satellite (DBS) está subvalorando la base lógica para las distinciones basadas en la tecnología bajo la Primera Enmienda. Yoo (2002: 207-08, 228-29) describe la creciente competencia entre el cable y DBS.

226. «Turner es bastante diferente de los futuros casos imaginables que envuelven nuevas tecnologías de la información, incluyendo Internet, que no incluye ningún problema de cuellos de botella» (Sunstein, I995: 1765).

227. FCC (2008: I0; tabla 2). 
más del $24 \%$ del mercado. ${ }^{228} \mathrm{Al}$ mismo tiempo, un consorcio de empresas lideradas por Sprint está preparando una nueva red inalámbrica basada en tecnología WiMax (Hansell, 2009). El eventual despliegue de servicios que funcionan sobre la banda de los $700 \mathrm{MHz}$ en una próxima licitación de espectro, promete que la competencia se intensificará aún más.

La existencia de esta vibrante competencia ha llevado a tribunales y reguladores a rechazar repetidamente los argumentos de que el mercado para servicios de Internet en la última milla está lo suficientemente concentrado para justificar la imposición de un requisito de acceso obligado. Por ejemplo, en Comcast Cablevision of Broward County, Inc. v. Broward County, ${ }^{229}$ el tribunal sentenció que la emergente competencia entre los proveedores de DSL y cable-modem hacía que el razonamiento de los cuellos de botella de Turner v. FCC fuera inadecuado para el servicio de cable-módem. ${ }^{230}$ Basado en un informe de la FCC que proyecta que la industria de banda ancha no parecía ser un monopolio natural y que en cambio podía caracterizarse por su vibrante competencia intermodal a partir de la migración por los consumidores desde servicios de conexión por línea telefónica a servicios de banda ancha, el tribunal concluyó que el razonamiento de los cuellos de botella establecido en Turner v. FCC no justificaba sujetar a Internet a una estándar de protección de la Primera Enmienda inferior al de los periódicos. ${ }^{231}$

Esta conclusión ha sido reforzada por sentencias judiciales y decisiones regulatorias posteriores que reconocen la competitividad del mercado de la banda ancha. Por ejemplo, en United States Telecom Ass'n v. FCC, ${ }^{232}$ el Circuito Federal de Washington D.C. revocó una decisión de la FCC que le exigía a las empresas de telefonía local compartir la

228. FCC (2008: 9; tabla I).

229. Comcast Cablevision of Broward County, Inc. v. Broward County (2000), I 24 F. Supp. 2 d 685 (S.D. Fla.).

230. Comcast Cablevision of Broward County, Inc. v. Broward County, pág. 696.

23I. Comcast Cablevision of Broward County, Inc. v. Broward County, pág. 696, cita a Inquiry Concerning the Deployment of Advanced Telecommunications Capability to All Americans in a Reasonable and Timely Fashion, and Possible Steps to Accelerate Such Deployment Pursuant to Section 706 of the Telecommunications Act of I996, Report, I4 F.C.C.R. 2398, 2423 II 48 (I999).

232. U.S. Telecom Ass'n v. FCC (2002), 290 F.3d 4I 5 (D.C. Cir.). 
porción de alta-frecuencia de sus loops con otros proveedores de DSL principalmente por «la robusta competencia... en el mercado de banda ancha» entre las tecnologías de DSL, cable-módem, banda ancha inalámbrica y otras. ${ }^{233}$ El Decreto de la FCC de 2005 sobre Acceso a Banda Ancha por Telefonía Fija igualmente resolvió que debido a que el mercado de servicio de banda ancha de la última milla ya era bastante competitivo y probablemente lo sería aún más en los años venideros, los elementos relacionados con el DSL deberían ser removidos de la lista de elementos de red que las empresas incumbentes de telefonía local deben proveer de conformidad con la Ley de $1996 .{ }^{234}$ Más recientemente, la Corte Suprema invocó específicamente esta conclusión in Pacific Bell Telephone Co. v. Linkline Communications, Inc., ${ }^{235}$ caso en el que señaló que «el marcado para servicios de Internet de alta velocidad es actualmente bastante competitivo» y que «los proveedores de DSL enfrentan una dura competencia de las empresas de TV cable y de los proveedores de conexiones inalámbricas y por satélite».236

Estos pronunciamientos hacen difícil poder entender cómo un tribunal podría invocar el argumento de los cuellos de botella desarrollado en Turner $v$. FCC para justificar una intrusión en la discreción editorial de los proveedores de Internet mayor que la permitida para los periódi$\cos ^{237}$ En ausencia de dicha justificación, el modelo de la prensa indica

233. U.S. Telecom Ass'n v. FCC, págs. 428-9.

234. Appropriate Framework for Broadband Access to the Internet over Wireline Facilities, Report and Order and Notice of Proposed Rulemaking, 20 F.C.C.R. I4,853, I4,883-87 III 55-64 (2005), petición de revisión denegada bajo el nombre Time Warner Telecom, Inc. v. FCC (2007), 507 F.3 d 205 (3d Cir.).

235. Pac. Bell Tel. Co. v. Linkline Commc’ns, Inc. (2009), I 29 S. Ct. I Io9.

236. Pac. Bell Tel. Co. v. Linkline Commc’ns, Inc., pág. I I 18, n. 2.

237. Algunos comentaristas han argumentado que los motores de búsqueda tienen suficiente "control de una ruta crítica de la comunicación» para justificar llevarlos dentro del ámbito de la excepción reconocida por Turner $v$. FCC. Véase Bracha y Pasquale (2008: I I9I), que cita a Turner v. FCC, pág. 657; Chandle (2007: I I26-27), lo mismo. Esta afirmación ignora el rechazo explícito de Turner $v$. FCC del argumento de que una parte dominante del mercado, por sí sola, justificaba sostener una restricción a la discreción editorial de los operadores de cable. En cambio, la decisión de la Corte volvió los controles de los operadores de cable sobre conexiones físicas exclusivas. Debido a que los motores de búsqueda no son propietarios de ninguna infraestructura física que conecta a los usuarios finales a Internet, a diferencia de los operadores de cable, ellos no 
que la discreción editorial de los proveedores de Internet representa un factor mayor, si no dominante, en su consideración para analizar bajo la Primera Enmienda.

\section{DENVER V. FCC: LA FALLIDA ANALOGÍA A FCC V. PACÍFICA Y LA HISTORIA DE LA REGULACIÓN}

La sentencia de la Corte Suprema en Denver v. FCC ${ }^{238}$ también experimentó con razonamientos alternativos para sujetar a los cableoperadores a niveles menores de escrutinio bajo la Primera Enmienda. Las malamente fragmentadas opiniones en el caso no pueden resumirse fácilmente. La controversia central se refirió a la constitucionalidad de las normas reglamentarias que autorizaban a los cableoperadores a negarse a transmitir programación indecente en sus accesos arrendados y en los canales de acceso público. ${ }^{239}$ La mayoría concluyó que «los cambios que están ocurriendo en la ley, la tecnología y en las estructuras industriales relacionadas con las telecomunicaciones» hacían «ahora poco aconsejable y definitivamente innecesario el escoger una analogía o un conjunto de palabras específicas», ${ }^{240}$ un aspecto de la sentencia que atrajo fuertes críticas de los otros cinco miembros de la Corte. ${ }^{241}$ En cambio, la mayoría relativa citó una larga lista de consideraciones, la más importantes fueron la similitud de las restricciones analizadas de aquellas analizadas en el caso FCC $v$. Pacifica, ${ }^{242}$ el hecho de que el reglamento regulaba "canales sobre los cuales históricamente los cableoperadores no han ejercido control

pueden bloquear a ningún usuario final de acceder a ningún contenido en particular. De hecho, cualquier usuario final descontento con los servicios proveídos por un motor de búsqueda en particular puede fácilmente cambiarse a otro motor de búsqueda con sólo pulsar unas pocas teclas y unos clics del mouse.

238. Denver Area Telecomms. Consortium, Inc. v. FCC (I996), 5 I 8 U.S. 727.

239. Denver Area Telecomms. Consortium, Inc. v. FCC, págs. 732-3.

240. Denver Area Telecomms. Consortium, Inc. v. FCC, págs. 742, voto de mayoría; pág. 768, J. Stevens, voto concurrente; págs. 775-7, J. Souter, voto concurrente; pág. 779-80, J. O'Connor, voto concurrente en parte y disidente en parte.

24I. Denver Area Telecomms. Consortium, Inc. v. FCC, págs. 780-7, J. Kennedy, concurrió en parte, concurriendo en la sentencia en parte y disidente en parte; págs. 8I 3 , 8I 7-I 8, J. Thomas, concurrió en la sentencia en parte y disidente en parte.

242. Denver Area Telecomms. Consortium, Inc. v. FCC, págs. 744-45, voto de mayoría; pág. 779-80, J. O’Connor, voto concurrente en parte y disidente en parte. 
editorial», ${ }^{243}$ y el hecho de que la programación en canales de libre acceso esté generalmente sujeta a revisión por el administrador de acceso de canales, quien puede ejercer discreción editorial en lugar del cableoperador. ${ }^{244}$

La viabilidad de cada uno de estos razonamientos respecto al cable es controvertida, ${ }^{245}$ especialmente luego de la sentencia siguiente de la Corte en United States v. Playboy Entertainment Group, Inc. ${ }^{246}$ Cualquier viabilidad de estas justificaciones para el cable, parecía no tener aplicación alguna a Internet. Adicionalmente, a diferencia de los cableoperadores, a los proveedores de Internet jamás se les ha privado de su discreción editorial respecto de sus capacidades de transmisión. ${ }^{247}$

243. Denver Area Telecomms. Consortium, Inc. v. FCC, págs. 76I, voto de mayoría; véase también págs. 793, 800, J. Kennedy, voto concurrente en parte, concurriendo en la sentencia en parte, $\mathrm{y}$ disidente en parte.

244. Denver Area Telecomms. Consortium, Inc. v. FCC, págs. 76 I-64, voto de mayoría.

245. Las cortes han reconocido hace tiempo que las diferencias tecnológicas (particularmente la capacidad del cable de bloquear canales que no se quieren en una casa) hacen a Pacifica inaplicable al cable. Véase United States v. Playboy Entm't Group, Inc. (2000), 529 U.S. 803, pág. 8I 5; Quincy Cable TV, Inc. v. FCC (I985), 768 F.2d I434, pág. I448, n. 3 I (D.C. Cir.); Cruz v. Ferre (I985), 755 F.2d I4I 5 , pág. I420 (I Ith Cir.); Cmty. Television of Utah, Inc. v. Roy City (I982), 555 F. Supp. I 164, pág. I 167-68 (D. Utah). Adicionalmente, permitir la regulación anterior que había privado por largo tiempo a los operadores de cable de la discreción editorial y la presencia de un «administrador de canal de acceso» que puede ejercer discreción editorial para justificar las limitaciones en los derechos de libre expresión de un operador de cable es equivalente a permitir que la regulación pasada sirva como una justificación constitucional para mayor regulación. Yoo (2003: 270-7I).

246. United States v. Playboy Entm't Group, Inc. (2000), 529 U.S. 803. Playboy apareció para acabar con todos los diferentes niveles inferiores del escrutinio de la Primera Enmienda presentados por el voto de mayoría de Denver y en cambio sometió la regulación en cuestión a escrutinio estricto (cf. pág. 8 I3-I 5). La señal más contundente es el hecho de que el voto disidente del Juez Breyer acordó que el escrutinio estricto era el estándar apropiado (pág. 836, J. Breyer, disidente). De hecho, el Juez Breyer pareció reprender al voto de mayoría por sugerir que él podría haber pensado de otra manera (pág. 836). A raíz de una decisión por unanimidad reconociendo que las restricciones de indecencia en la televisión por cable están sometidas a escrutinio estricto, es difícil ver cómo cualquiera de las justificaciones articuladas por el voto de mayoría de Denver para someter la televisión por cable a un estándar menor de la Primera Enmienda sigue siendo buen derecho.

247. Reno $v$. ACLU, págs. 868-69, señaló que que Internet nunca ha sido sometido a una regulación intrusiva. 
En resumen, los precedentes de la Corte Suprema sobre la televisión por cable niegan cualquier fundamento para interferir con la discreción editorial de los intermediarios de Internet. Al contrario, estos casos están repletos de declaraciones que reconocen que el ejercicio por los cableoperadores de su discreción editorial promueve importantes valores de libre expresión. Incluso aquellas sentencias que otorgaron un nivel de protección menor bajo la Primera Enmienda a los cableoperadores reconocen que, si bien las audiencias tienen un interés en acceder a la libre expresión, ese interés debe sopesarse contra la restricción de los intereses expresivos representados por la discreción editorial ejercida por los cableoperadores. ${ }^{248}$ Por lo tanto, estos casos reconocen, como mínimo, que el ejercicio por los cableoperadores de su discreción editorial beneficia a importantes valores de libre expresión. La inaplicabilidad de los razonamientos invocados para justificar el extender un menor nivel de protección bajo la Primera Enmienda al cable sugiere que debe predominar el interés en preservar la discreción editorial.

\section{RECONOCIMIENTO DE LA IMPORTANCIA DE LA DISCRECIÓN EDITORIAL DE LAS EMPRESAS DE TELEFONÍA}

Determinar el nivel de protección bajo la Primera Enmienda de que gozan los common carriers ha sido un puzle por bastante tiempo. A los analistas les ha sorprendido la escasez de decisiones judiciales sobre la relación entre la regulación de common carriage y la Primera Enmienda (Pool, 1983: 102-06; Ross, I998: 299). En efecto, aparte de algunas breves referencias que indican que los common carriers reciben una protección bajo la Primera Enmienda incluso menor que la de los cableoperadores, ${ }^{249}$ los tribunales raramente han tratado el tema. Los

248. Denver, 5 I 8 U.S., pág. 743 , voto de mayoría.

249. Denver, 5 I 8 U.S., pág. 739, voto de mayoría; FCC v. League, pág. 378. Por ejemplo, la Corte Suprema ofreció la observación tangencial en League of Women Voters que, "a diferencia de los common carriers, los organismos de radiodifusión están autorizados bajo la Primera Enmienda para ejercer la más amplia libertad periodística posible consistente con sus [deberes] públicos». FCC v. League, pág. 378, cita CBS v. FCC, pág. 395. A pesar de que esta breve declaración da a entender claramente que los derechos de la Primera Enmienda de los common carriers a discreción editorial son más limitados que los de los emisores, esta declaración simplemente hace una comparación 
analistas que han intentado sintetizar la doctrina se han encontrado con una Primera Enmienda tripartita, en la que la prensa recibe el más alto nivel de protección, los cableoperadores un nivel un poco menor, y los common carriers el nivel más bajo. ${ }^{250}$ Otros han sugerido que, debido a que el contenido está totalmente sujeto al control del suscriptor, los únicos intereses bajo la Primera Enmienda en juego son los de los suscriptores, y que los intereses expresivos del carrier no se afectan de ninguna forma. ${ }^{251}$

Desde los años ochenta, las decisiones de tribunales federales inferiores han empezado a reconocer que la discreción editorial sirve importantes valores de libre expresión incluso cuando es ejercida por los common carriers. La discusión siguiente se enfoca en dos líneas de casos. La primera confirmó el derecho de las empresas de telefonía a rehusarse a acarrear dial-a-porn. La segunda reconoció los derechos de las empresas de telefonía locales para transmitir programación de televisión por cable. En conjunto, ambas líneas de sentencias indican formas en que incluso los common carriers son fuentes importantes de intermediación.

\section{DIAL-A-PORN}

Si bien existían antecedentes históricos que reafirmaban los derechos de los common carriers para negarse a transmitir contenidos que fueran profanos, indecentes o groseros, ${ }^{252}$ el asunto llegó a su punto culminan-

relativa que no ofrece una declaración clara acerca del estándar de la Primera Enmienda para ser aplicado a los common carriers. Del mismo modo, al rechazar un desafío de la Primera Enmienda a la disposición del decreto que separó AT\&T, el que impedía que las empresas recién formadas de telefonía local entraran en la edición electrónica, el tribunal afirmó que «los common carriers están muy bien tratados de forma diversa de los propósitos de la Primera Enmienda que los medios de noticias tradicionales». United States $v$. W. Elec. Co. (1987), 673 F. Supp. 525, pág. 586, n. 273 (D.D.C. 1987). El tribunal hizo esta afirmación sin análisis.

250. Véase Huber y otros (I999: I279); Pool (I983: 2); Tribe (I988: I003-04); Zuckman y otros (I999: I85-89).

25I. Baker (I976: 42); Barron (I993: 382); Ross (I998: 295). Véase también Denver, 5 I 8 U.S., pág. 796, J. Kennedy concluyó que, en la medida en que el cable operador no está ejerciendo su propio criterio, «los derechos del operador de cable [no] informan este análisis».

252. Huber y otros (I999: I 275-76) discuten un caso de Ohio de I883 que falla el 
te con el surgimiento del dial-a-porn. El dial-a-porn marcó un cambio sustancial en la telefonía. En vez de conectar a dos personas que se hablan, el dial-a-porn se asemejaba más a una tecnología de transmisión que permitía que un solo mensaje de forma unidireccional alcanzara a miles de usuarios. ${ }^{253}$ El que las empresas de telefonía empezaran a transmitir contenidos masivos tuvo dos consecuencias. En primer lugar, los gobiernos empezaron a intentar ejercer discreción sobre los contenidos transmitidos en las redes telefónicas de la misma forma en que intentaron hacerlo respecto de los contenidos transmitidos por la radioemisión. En segundo lugar, las empresas de telefonía también empezaron a ejercer discreción editorial sobre dichos contenidos.

La primera controversia que llegó a la Corte Suprema fue el caso Sable, en el cual la Corte anuló un reglamento federal que prohibía mensajes telefónicos indecentes interestatales. ${ }^{254} \mathrm{El}$ caso Sable es importante por varias razones. En primer lugar, el que la Corte utilizara el criterio de análisis estricto para invalidar una restricción a la expresión basada en la transmisión telefónica, desmiente toda insinuación de que la comunicación telefónica estuviera sujeta sólo a la «más limitada protección bajo la Primera Enmienda». ${ }^{255}$ En segundo lugar, la opinión de la mayoría se enfocó casi enteramente en los derechos bajo la Primera Enmienda de los suscriptores conectados a la red; no se refirió de forma alguna al segundo asunto: los derechos de las empresas de telefonía para rehusarse a transmitir contenidos indecentes. ${ }^{256} \mathrm{La}$ discusión sobre este asunto sólo fue tocada en el voto de concurrencia del ministro Scalia, en que notó que «si bien hemos señalado que la Constitución impide que el Congreso pueda prohibir expresión indecente de esta forma, no hemos sentenciado que la Constitución obliga a las empresas de suministros públicos a transmitirla». ${ }^{257} \mathrm{La}$ declaración del ministro Scalia reconoció implícitamente la posibilidad de que las empresas de telefonía pudieran

derecho de una compañía de telefonía local a negarse a servir a un cliente que había usado vulgaridad.

253. Carlin Commc'ns, Inc. v. Mountain States Tel. \& Tel. Co. (I987), 827 F.2d I 29I, pág. 1294 (9 $9^{\text {th }}$ Cir.).

254. Sable Commc'ns of Cal., Inc. v. FCC (I989), 492 U.S. I I 5.

25 5. FCC v. Pacifica Found. (I978), 438 U.S. 726, pág. 748.

256. Sable, 492 U.S., págs. I 26-28.

257. Sable, 492 U.S., pág. 133. 
tener la discreción editorial suficiente para negarse a transmitir determinadas llamadas a pesar de su condición de common carriers.

La advertencia del ministro Scalia se ajustaba a una línea de sentencias de tribunales inferiores que confirmaron los derechos de las empresas de telefonía para rehusarse a transmitir dial-a-porn si así lo deseaban. ${ }^{258}$ Algunos casos afirmaron que la Primera Enmienda no se aplicaba a las empresas de telefonía porque no eran partes estatales, ${ }^{259}$ razonamiento que fue luego avalado por el ministro Thomas. ${ }^{260}$ Con estas sentencias, dichos tribunales reconocieron a los common carriers como voceros privados con el derecho de elegir qué expresión transmitir (Hammond, I995: II).

Más importante fue el que otras cortes sostuvieran que la regulación del common carriage no le impedía a las empresas de telefonía el ejercer su criterio de negocios para negarse a transmitir ciertos tipos de servicios. ${ }^{261}$ Como un connotado analista ha observado, el reafirmar el derecho de las empresas de telefonía para ejercer su criterio de negocios es esencialmente lo mismo que reafirmar sus derechos a ejercer su propia discreción editorial (Barron, I993: 386).

258. Véase Mountain States, 827 F.2d, págs. I 293-95; Carlin Commc’n, Inc. v. S. Bell Tel. \& Tel. Co. (I986), 802 F.2d I352, pág. I36I (I Ith Cir.); Network Commc'ns v. Mich. Bell Tel. Co. (1989), 703 F. Supp. I267, I 275 (E.D. Mich.); véase también Info. Providers' Coal. for Def. of First Amendment v. FCC (I99I), 928 F.2d 866, 877 (9th Cir.), que señaló que «un carrier es libre bajo la Constitución de terminar el servicio a los operadores de dial-a-porn en conjunto».

259. Véase Info. Providers' Coal., 928 F.2d, pág. 877; Mountain States, 827 F.2d, pág. I297; S. Bell, 802 F.2d, págs. I3 57-62; Network Commc’ns, 703 F. Supp., pág. I 274-77.

260. Denver Area Educ. Telecomm. Consortium, Inc. v. FCC (I996), 5 I 8 U.S. 727 , pág. 825 , J. Tomas, concurriendo parcialmente en la sentencia y voto disidente parcialmente, "Los common carriers son entidades privadas y pueden, en consistencia con la Primera Enmienda, ejercer discreción editorial en ausencia de una prohibición legal».

26I. Véase Mountain States, 827 F.2d, pág. I 294; véase también Network Commc’ns, 703 F. Supp., pág. I276, que se apoyó en el ejercicio de criterio empresarial de la compañía de teléfonos para sostener que su negativa a llevar dial-a-porn no constituye acción del Estado. 


\section{PROHIBICIÓN SOBRE LAS EMPRESAS DE TELEFONÍA PARA PRESTAR SERVICIOS DE TV CABLE}

La otra línea de sentencias que reconoce el derecho de los common carriers para ejercer su discreción editorial surgió de una serie de recursos basados en la Primera Enmienda en contra de leyes que le prohibían a las empresas de telefonía local ofrecer servicios de televisión por cable. ${ }^{262}$ Los tribunales habían sostenido de forma uniforme que esta restricción afectaba irremediablemente la capacidad de las empresas de telefonía para participar en una forma de expresión protegida. ${ }^{263} \mathrm{El}$ análisis más completo fue propuesto por el Cuarto Circuito en Chesapeake \& Potomac Telephone Co. of Virgina v. United States. ${ }^{264}$ En una sentencia algo contradictoria con los precedentes del dial-a-porn, el tribunal reconoció que el estatuto que le prohibía a las empresas de telefonía local ejercer control editorial sobre las llamadas implicaba que ellas no «eran miembros de la prensa» respecto de su servicio telefónico. ${ }^{265}$ A pesar de ello, en la medida que el reglamento les prohibía el «unirse a la prensa al operar... sistemas de cable» que incluyen «control editorial», dicho estatuto implicaba a la Primera Enmienda. ${ }^{266}$

262. Esta restricción fue instituida primero por la regla de la FCC. Véase Application of Telephone Cos. For Section 2 I4 Certificates for Channel Facilities Furnished to Affiliated Community Antenna Television Systems, Final Report and Order, 2I F.C.C.2d 307,325 II 49 (I970), aff'd sub nom. Gen. Tel. Co. of Sw. v. United States (I97I), 449 F.2d 846 (5th Cir.). Fue posteriormente codificada por el Congreso. Cable Communications Policy Act of I984, Pub. L. No. 98-549, $\mathbb{S} 2,98$ Stat. 2779, 2785 (previamente codificada en 47 U.S.C. $\$ 533$ (b) (r994)).

263. Véase US West, Inc. v. United States (I994), 48 F.3d I092, pág. I098 (9th Cir.), abandonado y remitido por consideración de irrelevancia, 5 I 6 U.S. I 55 (I996); Chesapeake \& Potomac Tel. Co. of Va. v. United States (1994), 42 F.3d I 8 I, I90 (4th Cir.), vacated and remanded for consideration of mootness, 5I6 U.S. 4I5 (I996); S. New England Tel. Co. v. United States (I995), 886 F. Supp. 2I I, 2 I 7 (D. Conn.); NYNEX Corp. v. United States, No. Civ. 93-323-P-C, I994 WL 77976I, at *2 (D. Me. Dec. 8, I994); Ameritech Corp. v. United States (I994), 867 F. Supp. 72 I, pág. 728 (N.D. Ill.); BellSouth Corp. v. United States (I994), 868 F. Supp. I335, pág. I339 (N.D. Ala.); US West, Inc. v. United State (I994), 855 F. Supp. I I 84, I I90 (W.D. Wash.).

264. Chesapeake \& Potomac Tel. Co. of Va.v. United States (1994), 42 F.3d I 8I (4th Cir.).

265. Chesapeake \& Potomac Tel. Co. of Va. v. United States, pág. I96.

266. Chesapeake \& Potomac Tel. Co. of Va. v. United States, pág. I96. 
En consecuencia, incluso si las telefónicas locales servían como common carriers para las comunicaciones de voz, en la medida en que deseaban empezar a prestar servicios de video, la Primera Enmienda protege sus derechos para ejercer discreción editorial sobre el contenido de dicho servicio. El hecho de que una empresa provea common carriage respecto de un servicio sobre el cual mantiene poco o nada de control editorial no le impide ofrecer otro servicio sobre el cual sí puede ejercer control editorial. Esto proveyó un buen contrapunto al reconocimiento en los casos CBS v. DNC, FCC v. Midwest y Denver de que las empresas que proveen contenidos de medios no pueden ser forzadas a convertirse en common carriers.

En conjunto, estos casos establecen algunos principios básicos aplicables a Internet. Primeramente, un proveedor que actualmente ejerce discreción editorial respecto del contenido que transmite, en conformidad con los principios de libre expresión reconocidos, no puede ser forzado a convertirse en common carrier. De hecho, el tribunal de distrito del caso Broward County aplicó ese principio cuando rechazó el argumento de que un proveedor de cable-módem que ejercía discreción editorial sobre su contenido podía ser forzado a separar parte de su servicio para usarlo como common carriage. ${ }^{267}$ Si bien algunos analistas han cuestionado si los servicios de los prestadores de Internet merecen protección bajo la Primera Enmienda, ${ }^{268}$ la mayoría de ellos reconoce que esos servicios promueven importantes valores de libre expresión. ${ }^{269}$

El argumento de que los prestadores de Internet ejercitan cierto grado de discreción editorial se ve reforzado por la historia de la responsabilidad por difamación de los ISP. Los prestadores que no tienen dis-

267. Comcast Cablevision of Broward County, Inc. v. Broward County (2000), I24 F. Supp. 2 d 685 , pág. 692 (S.D. Fla.).

268. Bracha y Pasquale (2008: I I90-92) para motores de búsqueda; Herman (2006: I I2-I3) para proveedores de banda ancha de última milla.

269. Aquellos que se mantienen escépticos deberían tener en cuenta que las películas y la programación de entretenimiento fueron alguna vez vistos fuera del ámbito de la Primera Enmienda. Véase Mut. Film Corp. v. Indus. Comm'n (I9I5), 236 U.S. 230, 243-44 (películas); Decision of Aug. 29, I928, 2 F.R.C. Ann. Rep. I 59, I6I (I928) (programación de entretenimiento). Estos casos son parte de una larga tradición en la que las nuevas tecnologías han nacido en el cautiverio de la Primera Enmienda. Véase Zuckman y otros (I999: 165-73). 
creción editorial serían inmunes a la responsabilidad por difamación. ${ }^{270}$ Así, el hecho de que los tribunales hayan emitido sentencias previas a la promulgación de la Communications Decency Act resolviendo que los ISP sean potencialmente responsables por difamación, ${ }^{271}$ reconocía implícitamente que los ISP ejercen algún grado de discreción editorial. Posteriormente, el Congreso incluyó una disposición en la Communications Decency Act otorgándole explícitamente inmunidad a los ISP por difamación. ${ }^{272}$ De hecho, el informe de sesión indica que el Congreso incluyó esta disposición específicamente para dejar sin efecto las sentencias que condenaron a los ISP por difamación. ${ }^{273}$ Si el ISP no tenía discreción editorial, dicha inmunidad estatutaria hubiera sido innecesaria. A mayor abundamiento, un título posterior del mismo estatuto le otorga inmunidad por el bloqueo y filtro, como buen samaritano, de contenido que sea «obsceno, procaz, lascivo, sucio, excesivamente violento, hostigante o de cualquier otra forma cuestionable». ${ }^{274} \mathrm{Al}$ hacerlo, el estatuto reconoció implícitamente los beneficios derivados de permitirle a los ISP ejercer discreción editorial. En efecto, los tribunales han sostenido uniformemente que los ISP pueden ejercer dicha discreción sin infringir la Primera Enmienda. ${ }^{275}$

En segundo lugar, una empresa que es common carrier claramente tiene el derecho a ofrecer servicios alternativos sobre los cuales ejerce discreción editorial. Por lo tanto, incluso si un proveedor de Internet históricamente no ha ejercido control editorial sobre ciertos servicios el gobierno no puede evitar que el proveedor pueda iniciar la prestación de

270. Véase Huber y otros (I999: I308); véase también Farmers Educ. \& Coop. Union of Am.v. WDAY (I959), Inc., 360 U.S. 525, págs. 526-27, 535.

27I. Véase, por ejemplo, Stratton Oakmont, Inc. v. Prodigy Servs. Co., No. 9403 I063, I995 WL 323710, at *5 (N.Y. Sup. Ct. May 24, I995), que concluyó que «la elección consciente del ISP para obtener los beneficios de un control editorial... abriéndose a una mayor responsabilidad», así permitiendo al ISP ser potencialmente responsable por difamación.

272. 47 U.S.C. $\$ 230(\mathrm{c})(\mathrm{I})(2006)$.

273. H.R. REP. NO. I04-458, en I94 (I996) (Conf. Rep.), reimpreso en I996 U.S.C.C.A.N. IO, 207-08.

274. 47 U.S.C. $\$ 230(c)(2)$.

275. Véase Green v. Am. Online (AOL), 3 I 8 F.3d 465, 472 (3d Cir. 2003); Langdon v. Google, Inc., 474 F. Supp. 2 d 622, 630-3I (D. Del. 2007). 
un nuevo servicio sobre el cual ejercita discreción editorial, sin infringir la Primera Enmienda.

\section{E. CONSECUENCIAS}

Tomadas en conjunto, estas diversas líneas de jurisprudencia reconocieron que el ejercicio de discreción editorial por los intermediarios que facilitan las comunicaciones electrónicas sirve a importantes valores de libre expresión. La Corte Suprema ha reconocido uniformemente que la restricción a su discreción editorial es inapropiada incluso si estos intermediarios tienen poder de mercado, si sólo sirven como conducto para la expresión de terceros, o si ejercitan su discreción en una forma estimada por terceros como sesgada.

Como mínimo, el derecho de los intermediarios como voceros representa una consideración compensatoria importante respecto de cualquier cálculo sobre libertad de expresión debe tener en cuenta para alcanzar el equilibrio. ${ }^{276}$ Un análisis razonable de los casos debería ir más allá: dado que ninguno de los razonamientos antes usados para justificar la restricción a los derechos de libre expresión de los radioemisores y cableoperadores serviría para aplicarse a Internet, estos precedentes indican que los intermediarios de Internet, como los periódicos, poseen una «libertad absoluta para promover sus propios puntos de vista sin tener que presentar puntos de vista opuestos». ${ }^{277}$

La posibilidad efectiva de que la intermediación pueda producir beneficios significativos plantea un problema analítico significativo para aquellos que desean limitar la libertad de los prestadores de Internet para ejercer su rol de intermediarios como mejor lo estimen. Los reconocidos beneficios de la discreción editorial socavan argumentos categóricos a favor de establecer obligatoriamente la no intermediación y obliga a los proponentes de la no intermediación a proveer alguna base para distinguir entre formas de intermediación permisibles y no permisibles. Como veremos, la historia de los esfuerzos previos para establecer dicha distinción causa serias dudas respecto su eventual éxito.

276. Véase Turner Broad. Sys., Inc. v. FCC (conocida como Turner II) (I997), 520 U.S. I 80, pág. 226-27, J. Breyer, concurriendo parcialmente.

277. FCC v. League, pág. 380. 


\section{LECCIONES DE INTENTOS PREVIOS DE REGULAR LA DISCRECIÓN EDITORIAL}

Como señalamos previamente, la Corte Suprema ha reconocido desde hace tiempo que la Radio Act de 1927 y la Communications Act de I934 reconocieron el importante rol que el ejercicio por los radioemisores de su discreción editorial juega en la promoción de valores de libre expresión. No obstante, tanto la FCC como su antecesora, la FRC, han mostrado una ambivalencia notable frente al ejercicio sin restricciones de la discreción editorial de los radioemisores. Por una parte, las normas contra el time brokering ${ }^{278}$ han intentado prevenir que los radioemisores ejerciten muy poco control editorial al limitar su capacidad de ceder el control sobre los contenidos emitidos a terceros. Por la otra, la hostilidad histórica de la FRC hacia las «emisoras de propaganda» y la Doctrina de Equidad (y sus antecedentes) han intentado prevenir que ejerciten demasiado control editorial.

Como la historia posterior demuestra, ninguno de estos esfuerzos fue exitoso. En ambos casos, las agencias fueron incapaces de desarrollar estándares para distinguir entre ejercicios de discreción editorial procedentes e improcedentes. Esa ambigüedad produjo un impacto desafortunado de coartar la transmisión de expresión, haciéndola a su vez más ortodoxa. Y lo que es peor, los operadores políticos pudieron usar estas normas para crear campañas sistemáticas para impedir la expresión de sus opositores.

\section{A. TIME BROKERAGE: REGULANDO EXIGUAMENTE LA DISCRECIÓN EDITORIAL}

La FRC y la FCC tienen una larga historia intentos para asegurar que los radioemisores no ejerciten demasiado su discreción editorial. Es interesante advertir que comenzando el año I92 I y antes de vender sus estaciones a RCA en I926, AT\&T adoptó un tipo de enfoque de mero conducto que los proponentes de la no intermediación favorecían al ofrecerles transmitir su programación a cualquiera que estuviese dispuesto a pagar las tarifas publicadas previamente (Shelanski, I997: I052-53). El entonces Secretario de Comercio Herbert Hoover criticó dicha práctica,

278. Nota de los traductores. Time brokering se refiere al arriendo de espacios de tiempo para que un tercero administre una radioemisora. 
más que nada por la cantidad de publicidad directa transmitida por las estaciones de AT\&T, pero se abstuvo de intervenir y dejó que la industria resolviera cuánta publicidad sería permitida. ${ }^{279}$

Prontamente las autoridades empezaron a expresar un escepticismo mayor respecto a esa forma de emisión tan poco intermediada. En su denegación de 1929 a la solicitud de tres radioemisoras de aumentar la cantidad de tiempo de emisión que sus licencias les permitían, la FRC rechazó ampliar las normas que regulaban la telefonía y telegrafía a la radioemisión, bajo las cuales «una radioemisora tendría que aceptar y transmitir para todas las personas en igualdad de condiciones sin discriminar en sus cobros». ${ }^{280} \mathrm{El}$ hacerlo habría privado al público de la discreción editorial ejercida por las radioemisoras, cuestión descrita como «una censura autoimpuesta ejercida por los directores de programación de las radioemisoras quienes, por el bien de la popularidad y vigencia de sus emisoras, seleccionarán programas de entretención y educacionales de acuerdo con las necesidades y deseos de sus audiencias invisibles». ${ }^{281}$ La FRC reconoció los beneficios que la intermediación otorgaba a las audiencias al razonar que el impedir que las radioemisoras ejercieran su discreción editorial «resaltaría el derecho del emisor de mensajes en perjuicio del público radioyente». ${ }^{282}$ Los analistas consideran que el énfasis de la FRC en la importancia de la discreción editorial de las radioemisoras anuló la posibilidad de existencia del tipo de sistema de radioemisión pagada no intermediada operado por AT\&T durante los años veinte (Shelanski, I997: I055), si bien la FCC a veces ha alabado a los licenciatarios por servir como conductos de la libre expresión de terceros. ${ }^{283}$

En las décadas siguientes, la herramienta primaria de la FCC para asegurar que los radioemisores ejerciten algún grado de discreción editorial ha sido su política en contra del time brokerage, que ocurre cuando

279. Shelanski (I997: I053), citando a Barnouw (I966: I77-78); véase también Huber y otros (I999: II) y Pool (I983: 35, I36-38).

280. Great Lakes Broad. Co. (I929), 3 F.R.C. Ann. Rep. 32, pág. 32, confirmada, 37 F.2d 993 (D.C. Cir. I930).

28I. Great Lakes Broad. Co., págs. 32-33.

282. Great Lakes Broad. Co., pág. 33.

283. Véase Adelaide Lillian Carrell, Proposed Findings of Fact and Conclusions of the Commission, 7 F.C.C. 2I9, 22I-22 II Io (I939) (hallazgos propuestos y conclusiones). 
una estación le vende bloques de tiempo en el aire a terceros. ${ }^{284}$ La FCC fue sumamente crítica respecto del time brokerage durante sus primeros años. Por ejemplo, en I940, la existencia de un contrato que designó a NBC como el único proveedor de programación de cuatro estaciones de radio de propiedad de Westinghouse, llevó a la FCC a amenazarla con no renovar dichas estaciones mientras Westinghouse no reemplazara el contrato por uno más ordinario de afiliación de red, bajo el cual Westinghouse tenía la responsabilidad final sobre la programación emitida por sus estaciones. ${ }^{285}$ En su decisión de I94I sobre Metropolitan Broadcasting Corp. ${ }^{286}$ la FCC rechazó la solicitud de renovación de su licencia a un licenciatario, en parte porque había delegado periódicamente casi la mitad del programa operativo de la estación a time brokers. ${ }^{287}$ En I963, la FCC revocó la licencia de Carol Music, Inc., en parte porque había celebrado un contrato de time brokerage que cubría doce horas diarias durante 6 días de la semana. ${ }^{288}$ En 1965 y 1966, la FCC multó a radioemisoras por celebrar contratos de time brokerage. ${ }^{289} \mathrm{Y}$ aún más importante fue la decisión de la FCC de 1976 sobre Cosmopolitan Broadcasting Corp., ${ }^{290}$ en que la FCC rechazó renovar una licencia de una estación de radio que vendió «virtualmente cada minuto disponible» a time brokers. ${ }^{291}$

284. 47 C.F.R. $\$ 73.3555$ note 2(j) (2007). Para la historia de la regulación de time brokerage, véase Lewyn (I995: 9-45) y Sewell (I995: 90-98).

285. Westinghouse Elec. \& Mfg. Co., Opinion and Order on Petition to Reconsider and Grant Without Hearing, 8 F.C.C. 195, I95-96 (I940).

286. Metro. Broad. Corp., Findings of Fact and Conclusions, 8 F.C.C. 558 (I94I).

287. Metro. Broad. Corp., Findings of Fact and Conclusions, 563 III 20-2 I, 575.

288. Revocation of License and Subsidiary Communications Authorization of Carol Music, Inc., for FM Broadcast Station WCLJ, Preliminary Statement, 37 F.C.C. 385 , 389-9I III IO-I3, 400-о ( I963).

289. WGOK, Inc., Memorandum Opinion and Order, 2 F.C.C.2d 245, 246 IIII 6-9 (1965); United Broad. Co., of N.Y., Inc., Memorandum Opinion and Order, 40 F.C.C. 224, 229 IIII 2I-23 (I965).

290. Cosmopolitan Broad. Corp., Decision, 59 F.C.C.2d 558 (I976), remitida por otros motivos, 58 I F.2d 9 I 7 (D.C. Cir. I978).

29I. Cosmopolitan Broad. Corp., 560 II 5, 56I II 7. El Circuito de D.C. caracterizó el ámbito del acuerdo de time brokerage de otra manera, señalando que sobre setenta y cinco por ciento del tiempo de las estaciones era vendido a time brokers, con aproximadamente veinte por ciento del tiempo restante vendido o cedido a otros para transmisiones religiosas. Cosmopolitan Broad., 58I F.2d at 919. 
Una regla de facto surgió: el time brokerage era permisible siempre y cuando no se tornara tan "extensivo» como para infringir las obligaciones de los radioemisores de mantener el control permanente sobre su programación. ${ }^{292}$ En resumen, se le permitió a los radioemisores servir como un mero conducto hasta cierto punto, pero no más allá. Es importante advertir que este criterio condenaría el tipo de enfoque de conducto tonto y no intermediado favorecido por quienes apoyaban la regulación, y prevé de forma evidente la discreción editorial como un bien que debe ser preservado en vez de condenado. Y aún más importante, la FCC fue algo vaga precisamente respecto a la cantidad de time brokerage que era permisible. Por un tema procedimental, a las radioemisoras la FCC les exigió inicialmente presentarle sus contratos de time brokerage, ${ }^{293}$ si bien una modificación posterior relajó este requisito y en cambio le permitió a las estaciones mantener los contratos en sus oficinas para ser inspeccionados por la FCC. ${ }^{294}$

Estas ambigüedades respecto a qué grado de delegación de la discreción editorial era demasiado, pronto empezaron a generar problemas. En algunos casos, la FCC aplicó sus políticas sobre contratos de brokerage que cubrían apenas ro minutos a la semana. ${ }^{295}$ La FCC también inicialmente aplicó sus reglas sobre time brokerage para negociar contratos, por ejemplo en el caso de un programador sindicado que vende publicidad directa contenida en un bloque de tiempo que había comprado, ${ }^{296}$ para algunos años después dejar de usarlas. ${ }^{297}$ Aún así, la FCC continuó

292. Véase Cosmopolitan Broad., 59 F.C.C.2d at 560-6I II 6; véase también Welcome Radio, Inc., Memorandum Opinion and Order, 20 F.C.C.2d 582, 583 II 4 (I969).

293. Financial Ownership and Other Reports of Broadcast Licensees, Io Fed. Reg. 97 I 8, 97 I 8-I9 (Aug. 7, I945) (requiriendo la presentación de los contratos para «ventas de bultos de tiempo" de dos horas o más).

294. Re-regulation of Radio and Television Broadcasting, 25 Rad. Reg. 2d (P \& F) I7I9, I722 If 5 (g) (nov. 2, I972).

295. Véase Eller Telecasting Co., Memorandum Opinion and Order, I9 F.C.C.2d 913, 9I3-I4 II 4 (I969), que aplicó las regulaciones de time brokerage a un noticiero semanal de diez minutos dirigido a audiencias hispánicas; Inc., Memorandum Opinion and Order, 2 F.C.C. 2 d 245, 245 II 2 ( 1965 ), que aplicó los requerimientos de time brokerage a programas de domingo de quince minutos vendidos a cantantes aficionados.

296. Véase Rand Broad. Co., 22 Rad. Reg. 2 d (P \& F) I 5 5, I 5 5-56 (June 9, I97 I).

297. Clarifying Paragraph (c) of Section I.6I3, Concerning the Filing of Agreements 
advirtiendo que un uso extendido de contratos de time brokerage podía infringir la responsabilidad de la estación de mantener control editorial sobre su programación. ${ }^{298}$

Una declaración reglamentaria de I980 marcó un cambio importante en el enfoque de la FCC respecto al time brokerage. En vez de expresar hostilidad hacia el time brokerage, la FCC adoptó una política de «incentivar los contratos de time brokerage» como una forma de «impulsar el involucramiento de minorías en la radioemisión». 299 Adicionalmente, la FCC esperaba que al cambiar su posición respecto, ello promovería la programación dirigida a «audiencias específicas cuyos gustos no eran cubiertos porque eran grupos demasiado pequeños como para poder mantener una programación semanal completa». ${ }^{300}$ Dicho lo anterior, la FCC rechazó cualquier «intento de transformar el servicio de radio en un common carrier», ${ }^{301}$ y continuó enfatizando que cada radioemisor mantenía la responsabilidad final por la programación emitida desde sus instalaciones. ${ }^{302}$ La FCC rechazó los análisis ex ante de contratos de time brokerage por su preocupación de que dichas revisiones pudieran desincentivar esta práctica, prefiriendo en cambio «resolver dichos problemas cuando ocurrieran». ${ }^{303}$ Rechazó implícitamente el establecimiento de un límite numérico claro, concluyendo que «la cantidad de time brokerage no es realmente el asunto. En cambio, es el grado en que el licenciatario renunciaba a sus responsabilidades a favor de los time brokers». ${ }^{304} \mathrm{La}$

Involving the Sale of Broadcast Time for Resale, Order, 33 F.C.C.2d 653, 654 IIII 4-7 (I972).

298. Id. en 653-54 II 3 .

299. Petition for Issuance of Policy Statement or Notice Inquiry on Part-Time Programming, Policy Statement, 82 F.C.C.2d I07, I07-09 IIII I-4 \& n.8, I 20 II 3 I (I980).

300. Petition for Issuance of Policy Statement or Notice Inquiry on Part-Time Programming, $\mathrm{I} 20$ II $3 \mathrm{I}$.

30I. Petition for Issuance of Policy Statement or Notice Inquiry on Part-Time Programming, I I 4 II I 7 .

302. Petition for Issuance of Policy Statement or Notice Inquiry on Part-Time Programming, IO9 II 5 , I I 3 II I 5 .

303. Petition for Issuance of Policy Statement or Notice Inquiry on Part-Time Programming, I I 2-I 3 IIII I3-I4, I I 4 II I7.

304. Petition for Issuance of Policy Statement or Notice Inquiry on Part-Time Programming, I I 4 II 17 . 
FCC también rechazó emitir normas más claras en beneficio de productores independientes con poca experiencia, basándose principalmente en que el actual enfoque caso a caso no había demostrado ser demasiado gravoso y que los radioemisores podían otorgar a estos productores independientes una asesoría clara. ${ }^{305}$ Finalmente, la FCC rechazó los llamados para evitar que los radioemisores censuraran, declarando en cambio que el interés del público sería mejor servido manteniendo su decisión de que los radioemisores fueran responsables de sus decisiones editoriales. ${ }^{306}$

Con la desregulación que facilitaba la entrada de nuevas estaciones de radio durante los ochenta, las estaciones de radio empezaron a usar el time brokerage no solamente para una programación más especializada, sino también para ampliar dicha programación y cubrir así todo el tiempo de emisión disponible (Lewyn, I995: I I-I 2). En I989, la FCC liberalizó aún más su política de time brokerage al permitirle a una estación el efectuar corretaje del tiempo de otra estación que operaba en el mismo mercado. ${ }^{307}$ Empezando con la decisión fundamental del caso Russo, ${ }^{308}$ la FCC permitió expresamente muchos de estos acuerdos de time brokerage más extensivos (Lewyn, I995: 4; Sewell, ı995: 98), y eventualmente codificó este criterio más amplio de aceptación del time brokerage en sus normas. ${ }^{309}$ En todo caso, la FCC no llegó a acoger totalmente la no intermediación, resaltando la responsabilidad permanente de los radioemisores de ejercer su control editorial sobre la programación transmiti-

305. Petition for Issuance of Policy Statement or Notice Inquiry on Part-Time Programming, I I 4 II I 8 .

306. Petition for Issuance of Policy Statement or Notice Inquiry on Part-Time Programming, I I 8-I9 III 28-29.

307. Reexamination of the Commission's Cross-Interest Policy, Policy Statement, 4 F.C.C.R. 2208, 2214 IIII 37-39 (1989).

308. Roy R. Russo, Esq., Letter, 5 F.C.C.R. 7586,7587 (I990).

309. Revision of Radio Rules \& Policies, Report and Order, 7 F.C.C.R. 2755 , 2787 II 63 (I992), reconsiderado, 7 F.C.C.R. 6387 (I992) (First Reconsideration Order), reconsiderado, 9 F.C.C.R. 7I83 (I994) (Second Reconsideration Order). Las normas prohibían que las estaciones que operaran en el mismo mercado usaran el time brokerage para duplicar más del veinticinco por ciento de su programación. Id. en 2789 II 66. El time brokerage de más del quince por ciento del tiempo de otra estación constituiría la copropiedad para propósitos de las normas de propiedad local y nacional. Id. en 2788 89 II 65. 
$\mathrm{da}^{310}$ y rechazando ciertos acuerdos de corretaje cuando los dueños de las estaciones renunciaban a esta responsabilidad (Lewyn, I995: 5-6).

Más importante fue que la FCC continuó siendo incapaz de emitir un estándar claro para lo que representaba un grado aceptable de no intermediación, adhiriéndose en cambio a un enfoque caso a caso. ${ }^{311}$ Algunos analistas han criticado que las nuevas políticas de la FCC sobre time brokerage son demasiado permisivas y han señalado que disminuían la diversidad de programación (Sewell, I995: 99-I00). Otros además han luchado para determinar el fundamento en virtud del cual algunos acuerdos de time brokerage eran aprobados o rechazados, y estos expertos alegan que el enfoque caso a caso ha producido una confusión regulatoria que no otorga una orientación significativa. ${ }^{312}$ La FCC continuamente ha rehusado escuchar los llamados para emitir un estándar más claro, basada en que el enfoque caso a caso garantiza una mayor flexibilidad para los radioemisores. ${ }^{313}$

\section{B. LA DOCTRINA DE EQUIDAD: SOBRERREGULACIÓN DE LA DISCRECIÓN EDITORIAL}

Al mismo tiempo que la FRC y la FCC han luchado por delinear cuándo las radioemisoras han ejercido muy poco control editorial, también han luchado de forma aún más controvertida con estándares para determinar cuándo las radioemisoras han ejercido demasiado control editorial. ${ }^{314}$ Nuevamente, los primeros días de la industria radial son instructivos. Al-

3 IO. Revision of Radio Rules \& Policies, 7 F.C.C.R. at 2787 II 63; accord First Reconsideration Order, 7 F.C.C.R. at 640I II 63 («Hacemos hincapié en que el licenciado es últimamente responsable por toda la programación puesta al aire en su estación, independientemente de su origen»).

3 Ir. Second Reconsideration Order, 9 F.C.C.R. at 7 I92 II 54; First Reconsideration Order, 7 F.C.C.R. at 640I II 63; véase también Revision of Radio Rules \& Policies, 7 F.C.C.R. at 2789 II 67 , que opta por la supervisión de los contratos de time brokerage a través de un proceso de quejas y de cumplimiento en lugar de reglas por adelantado.

3 I2. Lewyn (I995: 45-48, 56-57); véase también Brooke Commc'ns, Inc., Memorandum Opinion and Forfeiture Order, I4 F.C.C.R. 6247, 6249 II 7 (I999).

3I3. Véase Second Reconsideration Order, 9 F.C.C.R. at 7I92 II 54.

3 I4. La discusión que sigue se basa en gran medida en la excelente crítica de la Doctrina de Equidad de Krattenmaker y Powe (I994: 6I-65, 237-75). 
gunas estaciones desarrollaron voces editoriales distintivas sobre puntos de vista particulares. Por ejemplo, WEVD en Nueva York, servía como «la portavoz del Partido Socialista». ${ }^{315}$ WIBA en Madison, Wisconsin, hablaba por el movimiento Progresista de Robert LaFollette. ${ }^{316}$ WCFL en Chicago ofrecía programación de interés para los sindicatos. ${ }^{317}$

Durante su segundo año de existencia, la FRC fue algo tolerante con estas estaciones. De hecho, en agosto de I928 la FRC declaró que «no limitaría a ninguna estación... que fuera la portavoz de una minoría política o religiosa relevante» siempre y cuando la estación programara "con la debida atención a las opiniones de otros». ${ }^{318}$

Sin embargo, hacia 1929, la FRC se había vuelto más escéptica de las estaciones con voces editoriales tan distintivas. En su decisión del caso Great Lakes Broadcasting ${ }^{319}$ se preguntaba si dicha discreción editorial se estaba aplicando de forma demasiado vigorosa, como cuando un radioemisor transmitía programas «interesantes o valiosos sólo para un pequeño segmento del público» o cuando servían «a los intereses particulares de individuos o grupos». ${ }^{320}$ La FRC condenó a dichas emisoras como "estaciones de propaganda», un término que la FRC intentó débilmente suavizar alegando que era «usada por razones de conveniencia y no de forma derogatoria». ${ }^{321}$ La FRC justificó sus críticas invocando la actualmente desacreditada doctrina de la escasez. Debido a que «no existe espacio en la banda de radioemisión para que cada escuela de pensamiento, ya sea religiosa, política, social y económica, tenga su propia radioemisora, su micrófono en el éter», cada radioemisor estaba obli-

3 I 5. C.A. Cummins (Aug. 29, I928), 2 F.R.C. Ann. Rep. I 59, pág. I60.

316. C.A. Cummins (Aug. 29, I928), 2 F.R.C. Ann. Rep. I 59, pág. I60.

317. Chi. Fed'n of Labor v. FRC (I929), 3 F.R.C. Ann. Rep. 36, pág. 36.

318. Michael T. Rafferty (Aug. 22, I928), 2 F.R.C. Ann. Rep. I 54, pág. I 55 . Véase también C.A. Cummins, 2 F.R.C. Ann. Rep., pág. I60: «Siempre que la evidencia demuestre que una estación particular sirve como portavoz para una minoría religiosa o política sustancial, no importando cuánto puedan estar en desacuerdo los miembros individuales de la comisión con los puntos de vista de esa minoría, la comisión ha tomado acción favorable a la estación».

3 I9. Great Lakes Broad. Co. (I929), 3 F.R.C. Ann. Rep. 32, aff 'd, 37 F.2d 993 (D.C. Cir. I930).

320. Great Lakes Broad. Co., pág. 34 .

32. Great Lakes Broad. Co., pág. 34. 
gado a ofrecer una «programación amplia» que contemplara «en justa proporción... los gustos, necesidades y deseos de todos los grupos sustanciales dentro de público oyente». ${ }^{322}$ En efecto, la FRC habría negado de plano el otorgar licencias a las estaciones de propaganda si no hubiera sido porque ya estaban establecidas, y la Comisión señaló que, si llegara a tener la oportunidad, favorecería a los solicitantes que ofrecieran un servicio más general. ${ }^{323}$

En la decisión inmediatamente posterior al caso Great Lakes Broadcasting, la FRC rechazó la solicitud de WCFL (operada por la Federación del Trabajo de Chicago) de incrementar su potencia y el número de horas que podía transmitir basada en que «no existe lugar para estaciones que sirvan a un grupo en particular, pues todas las estaciones deben servir al público en general y servir el interés público en contra de intereses de grupos o clases». ${ }^{324}$

Pero quizás la postura más notoria en contra de la discreción editorial fue la caducidad por la FRC de la licencia de la estación de radio operada por «Fighting Bob» Shuler, un pastor que usaba tanto su pulpito como su enormemente popular estación de radio para criticar al alcalde, al jefe de la policía, al fiscal de distrito, al fiscal de la ciudad y al colegio de abogados local, todos de la ciudad de Los Angeles, por su corrupción y vínculos con el crimen organizado. ${ }^{325}$ Obviamente, la programación ofrecida por Shuler precisamente representaba el tipo de discurso político importante requerido por los ciudadanos. Y a pesar de la evidencia sustancial y muchas veces no controvertida a favor de las acusaciones de Shuler (Orbison, I977: 463-64, 466), la FRC en pleno votó en contra de Shuler, en parte porque estimó que sus programas eran sensacionalistas en vez de ser instructivos. ${ }^{326}$ La Corte de Apelaciones del Circuito de D.C. confirmó la decisión de la FRC, y la Corte Suprema rechazó revisar el caso. ${ }^{327}$

322. Great Lakes Broad. Co., pág. 34 .

323. Great Lakes Broad. Co., pág. 35.

324. Chi. Fed'n of Labor v. FRC (I929), 3 F.R.C. Ann. Rep. 36, pág. 36.

325. Véase Orbison (I977: 463-64). Véase también Krattenmaker y Powe (I994: 24$25,27-28)$.

326. Orbison (1977: 466). Véase también Trinity Methodist Church, S. v. FRC (I932), 62 F.2d 850, 85 I (D.C. Cir.), cert. denied, 288 U.S. 599 (I933).

327. Trinity Methodist Church, 62 F.2d, pág. 854 . 
De igual modo, en su decisión de I940 del caso Mayflower Broadcasting Corp., ${ }^{328}$ la FCC criticó duramente la política de la Yankee Network de transmitir editoriales a favor de sólo algunos candidatos o temas políticos, renovando su licencia sólo después de que la Yankee Network prometió no seguir adelante con sus editoriales. ${ }^{329}$ Al hacer esto, la FCC declaró categóricamente que la programación de un licenciatario «no puede dedicarse a apoyar los principios que considera más favorables. En resumen, un radioemisor no puede ser un partidario». ${ }^{330}$

Nueve años después, la FCC dio un giro abruptamente y resolvió que los radioemisores tiene la obligación de tener una postura editorial respecto de los asuntos públicos que preocupaban a sus audiencias. ${ }^{331}$ Al mismo tiempo, la FCC resolvió que los radioemisores «deben operar sobre la base de una equidad generalizada» al «permitir una oportunidad razonable para la presentación de todas las posiciones responsables respecto de asuntos que tuvieran la suficiente importancia como para merecer tiempo en el aire». ${ }^{332}$ Inicialmente, el cumplir con la Doctrina de Equidad era sencillamente una circunstancia que se tomaba en consideración al momento de solicitar la renovación de licencia, lo que implicaba que su fiscalización consistía básicamente en amonestaciones piadosas (Barron, I96r: 9). La FCC empezó a darle real efectividad a la doctrina en 1962, cuando empezó a resolver casos basados en quejas surgidas de la falta de equidad. ${ }^{333}$ En su decisión de 1960 del caso Red Lion v. FCC, la Corte Suprema la dio a la doctrina su imprimátur basada ampliamente en la ahora desacreditada doctrina de la escasez. ${ }^{334}$ Posteriormente el Congreso intentó aprobar un estatuto prohibiéndole a los

328. Mayflower Broad. Corp., Proposed Findings of Fact and Conclusions, 8 F.C.C. 333 (1940).

329. Mayflower Broad. Corp., Proposed Findings of Fact and Conclusions, págs. 339-4I.

330. Mayflower Broad. Corp., Proposed Findings of Fact and Conclusions, pág. 340.

33 I. Editorializing by Broadcast Licensees, Report of the Commission, I3 F.C.C. I 246, I 249-50 III 6-7 (I949).

332. Editorializing by Broadcast Licensees, Report of the Commission, I 250 II 7.

333. Krattenmaker y Powe (I994: 62-63). El primer caso parece ser Complaint Under «Fairness Doctrine» Requirements, 40 F.C.C. 508 (I962). Para el razonamiento de la FCC para el cambio en la política, véase «Fairness Doctrine» Implementation, 40 F.C.C. $582,583-85$ (1963).

334. Red Lion v. FCC, págs. 400-0I. 
radioemisores públicos editorializar, ${ }^{335}$ sólo para que esta prohibición fuera derogada por la Corte Suprema en el caso League of Women Voters. ${ }^{336}$ Eventualmente, la FCC abolió la Doctrina de Equidad en I 987.337

Tal como el intento de la FCC de restringir los acuerdos de time brokerage, tanto quienes apoyan como quienes critican la Doctrina de Equidad reconocen que a la FCC le costó poder desarrollar criterios coherentes para resolver los reclamos basados en la Doctrina de Equidad. ${ }^{338}$ A mayor abundamiento, la Doctrina de Equidad prontamente hizo surgir un montón de difíciles problemas. Por ejemplo, un grupo que apoyaba el Tratado de Prohibición de Ensayos Nucleares argumentó exitosamente que la Doctrina de Equidad obligaba a una estación que transmitía un programa pagado por la oposición al tratado, a darle tiempo en el aire al punto de vista contrario incluso si el grupo que abogaba por el punto de vista contrario no podía pagar por él. ${ }^{339}$

Decisiones posteriores de la FCC ampliaron la Doctrina de Equidad al avisaje comercial. John Banzal, quien luego sería profesor de derecho, alegó exitosamente que la transmisión por una estación afiliada a CBS de publicidad que mostraba el consumo de cigarrillos como socialmente aceptable, le daba derecho a tiempo en el aire gratuito para mostrar los potenciales daños del cigarrillo. ${ }^{340}$ A pesar de los intentos de la FCC de

335. Omnibus Budget Reconciliation Act of I98 I, Pub. L. No. 97-35, sec. I229, $\mathbb{S}$ 399, 95 Stat. $357,730$.

336. FCC v. League, pág. 402.

337. Complaint of Syracuse Peace Council Against Television Station WTVH Syracuse, New York, Memorandum Opinion and Order, 2 F.C.C.R. 5043, 5043 II 2 (I987), y la petición de revisión denegada, 867 F.2d 654 (D.C. Cir. I989) (fallando la decisión de la Comisión basada en un razonamiento de interés público, sin llegar a la cuestión constitucional).

338. Krattenmaker y Powe (I994: 26I-70) caracteriza la Doctrina de Equidad como «un principio legal incoherente»; Rowan (I984: 5I) señala que «la confusión abunda sobre el tema»; Barron (I96I: I8) cita la ausencia de cualquier sistema de criterios para resolver los reclamos de equidad.

339. Responsibility Under the Fairness Doctrine, 40 F.C.C. 576 (I963).

340. Complaint Directed to Station WCBS-TV, New York, N.Y., Concerning Fairness Doctrine, 8 F.C.C.2d 381, 382, reconsiderada en parte en 9 F.C.C.2d 92I (I967). Applicability of the Fairness Doctrine to Cigarette Advertising, Io F.C.C.2d I6 (I967). Banzhaf v. FCC, 405 F.2d Io82 (D.C. Cir. I968). 
restringir su decisión sólo a los cigarrillos, ${ }^{341}$ las decisiones siguientes acogieron reclamos bajo la Doctrina de Equidad, por ejemplo, en contra de avisaje de marcas de autos de lujo ${ }^{342}$ y empresas petroleras, ${ }^{343}$ y rechazaron reclamos que argumentaban que la publicidad de compactadores de basura era un comentario sobre el reciclaje, ${ }^{344}$ o que la publicidad del dentífrico Crest era un comentario sobre la fluorización del agua potable. ${ }^{345}$ Los emisores se mostraron renuentes a vender publicidad a organizaciones como empresas petroleras o grupos que se oponían a un referéndum de reciclaje por temor a tener que dar espacios gratuitos a aquellos que sostenían un punto de vista opuesto. ${ }^{346}$ La FCC subsecuentemente reconsideró su posición, emitiendo un nuevo decreto revocando el caso Banzhaf v. FCC ${ }^{347}$ y concluyendo en cambio que la publicidad de productos estándar no tocaban asuntos de interés público lo suficientemente controversiales como para gatillar la Doctrina de Equidad. ${ }^{348}$ Los reclamos posteriores fueron resueltos más fácilmente. ${ }^{349}$

34I. Television Station WCBS-TV, New York, N.Y., Memorandum Opinion and Order, 9 F.C.C.2d 921, 942-43 Il 44 (I967).

342. Véase Complaint by Friends of the Earth Concerning Fairness Doctrine Re Station WBNB-TV, New York, NY, 24 F.C.C.2d 743, 750 (I970) (concluyendo que «el organismo de radiodifusión tiene una obligación de informar al público. . . en [el] asunto importante de la contaminación del aire causada por los automóviles). Friends of the Earth v. FCC, 449 F.2d I 64 (D.C. Cir. I97I).

343. Complaint by Wilderness Society and Friends of the Earth Concerning Fairness Doctrine Re National Broadcasting Co., 30 F.C.C.2d 643, 646, reconsiderada en 3 I F.C.C.2d 729 (I97I).

344. Complaint by John S. MacInnis, Consumers Arise Now, San Francisco, Cal. Concerning Fairness Doctrine Re Station KGO-TV, 32 F.C.C.2d 837, 838 (I97I).

345. Complaint by National Health Federation, Delaware, Ohio, Concerning Fairness Doctrine, 58 F.C.C.2d 3I4, 3 I6 (I976).

346. Inquiry into Section 73.I9Io of the Commission's Rules and Regulations Concerning the General Fairness Doctrine Obligations of Broadcast Licensees, Report, I02 F.C.C.2d I42, I75-78 IIII 48-52 (I985) (I985 Fairness Report).

347. Banzhaf v. FCC (1968), 405 F.2d 1082 (D.C. Cir.).

348. Handling of Public Issues Under the Fairness Doctrine and the Public Interest 1974 Fairness Report Standards of the Communications Act, Fairness Report, 48 F.C.C.2d I, 24-26 IIII 66-70 (I974) (I974 Fairness Report).

349. Complaint by Peter C. Herbst et al. Concerning Fairness Doctrine Re Station WMTW-TV, 40 F.C.C.2d II5, i 8 (I973) (rechazando el reclamo de la Doctrina de Equidad sobre la base de anuncios de motos de nieve), aff'd sub nom. Pub. Interest Re- 
Lo que es más importante es que en la práctica la Doctrina de Equidad tendió a aminorar ostensiblemente el tipo de expresión para cuya promoción había sido creada. La FCC ha reconocido que el primer criterio de la Doctrina, que obligaba a los radioemisores a cubrir asuntos controversiales en beneficio de las comunidades a las que sirve, es esencialmente inaplicable. La FCC, en efecto, admitió: «No tenemos la intención de involucrarnos en la selección de asuntos a discutirse, ni esperamos que un radioemisor cubra cada uno de los asuntos importantes que puedan surgir en su comunidad». ${ }^{350}$ Como consecuencia, las decisiones de un radioemisor en relación con este primer criterio de la Doctrina de Equidad estaban amparadas por una «presunción de cumplimiento» ${ }^{351} \mathrm{y}$ violarían la doctrina «sólo en raras ocasiones». ${ }^{352}$ Como indicó la corte del Circuito del Distrito de Columbia, la obligación impuesta por el primer criterio «no era amplia y podía cumplirse presentando el mínimo del asunto controvertido». ${ }^{353}$ En efecto, sólo en una ocasión la FCC sancionó a una estación por no haber cubierto un asunto controversial, y ese caso no surgió bajo las circunstancias que reflejaban los requerimientos reales de los radioyentes. ${ }^{354}$ Los radioemisores enfrentaban riesgos más

search Group v. FCC, 522 F.2d 1060 (Ist Cir. I975).

350. 1974 Fairness Report, 48 F.C.C.2d at Io II 25.

35 I. Handling of Public Issues Under the Fairness Doctrine and the Public Interest Standards of the Communications Act, Memorandum Opinion and Order, 89 F.C.C.2d 916, 925 II 23 (I982).

352. Complaint of Brent Buell, Memorandum Opinion and Order, 97 F.C.C.2d 55 , 57 II 8 (I984).

353. Am. Sec. Council Educ. Found. v. FCC, 607 F.2d 438, 444 n.r6 (D.C. Cir. I979).

354. Este caso surgió cuando una Representante del Congreso de Hawaii, quien era la principal patrocinadora de la legislación para limitar la minería a cielo abierto, pidió a una estación de radio de West Virginia que transmitiera una cinta de once minutos que defendía su posición durante el tiempo en que la legislación estaba siendo considerada por el Congreso y presentada al Presidente para su firma. Complaint of Representative Patsy Mink et al. Against Radio Station WHAR, Clarksburg, W. Va., Memorandum Opinion and Order, 59 F.C.C.2d 987, 987 II 2 (I976). Cuando la estación se negó, la Representante elevó exitosamente su queja de la Doctrina de Equidad. Id en 997 II 30. Curiosamente, una de las principales bases para concederle su reclamo fue el hecho que el periódico local había cubierto la historia en su página principal por nueve días durante el período clave de once días cuando la legislación estaba siendo debatida y sometida al veto presidencial. Id. en 995 II 24. Como Thomas Krattenmaker y Lucas Powe señala- 
relevantes bajo el segundo criterio si no podían presentar los temas de forma tal que la FCC los considerara como suficientemente equitativos. En consecuencia, la mejor forma que tenían los radioemisores para eludir su responsabilidad por infracciones era sencillamente el evitar cubrir asuntos controversiales en su totalidad. El efecto fue una disminución neta en la cantidad de expresión promovida por la Doctrina de Equidad y que había justificado su creación. A mayor abundamiento, el hecho de que los radioemisores sólo necesitaran incluir opiniones «principales» $\mathrm{O}$ «significativas» llevaba inevitablemente a asegurar que la poca expresión presentada fuera derechamente ortodoxa. ${ }^{355}$ En efecto, los radioemisores para los cuales la Doctrina de Equidad presentaba los peores problemas eran aquellos dedicados la mayor parte del tiempo a asuntos controversiales y que ofrecían los puntos de vista más distintivos. ${ }^{356}$

El peligro de que la exigencia de cobertura equitativa pudiera inhibir la expresión política fue lo que justificó que la Corte Suprema invalidara el derecho a réplica para los periódicos. ${ }^{357} \mathrm{La}$ Corte desestimó calificando de «especulativos» los argumentos de que la Doctrina de Equidad tendrían el mismo impacto sobre la radioemisión y explicó que, «si la experiencia en administrar estas doctrinas indica que han tenido

ron, este razonamiento tiene el efecto de permitir el hecho de que un asunto ya está siendo cubierto extensivamente en otros medios para obligar a las radioemisoras a proveer una cobertura duplicada (I994: 247).

355. Véase Inquiry into Section 73.1910 of the Commission's Rules and Regulations Concerning the General Fairness Doctrine Obligations of Broadcast Licensees, Report, I02 F.C.C.2d I42, I 88-90 IIII 69-7 I (I985 Fairness Report); véase también CBS v. DNC (Brennan, J., voto disidente) ( « Bajo la Doctrina de Equidad, los organismos de radiodifusión generalmente tienden a permitir sólo puntos de vistas establecidos —o al menos moderados- para entrar al mercado mundial de ideas de la radiodifusión'»); Brandywine-Main Line Radio, Inc. v. FCC, 473 F.2d I6, 78 (D.C. Cir. I972) (Bazelon, C.J., voto disidente) ( «Los puntos de vista polémicos están siendo revisados a favor de la insipidez aburrida de una opinión más aceptable».); Krattenmaker y Powe (I994: 248); «En esos asuntos que son incuestionablemente controversiales, sin embargo, es obvio que se hace poca o ninguna editorialización» (Barron, I96I: I4).

356. Véase I985 Fairness Report, I02 F.C.C.2d at I89-90 If 7i \& nn.r68-69.

357. Véase Miami Herald Publ'g Co. v. Tornillo, 4I 8 U.S. 24I, 257 (I974) («Frente a las sanciones [de la ley impugnada]. . . los editores bien podrían concluir que el camino seguro es evitar la controversia. Por lo tanto, la cobertura política y electoral sería mitigada o reducida».). 
un efecto neto de reducir en vez de ampliar el volumen y calidad de la cobertura, habrá tiempo suficiente para reconsiderar sus implicancias jurisdiccionales». .358

Ahora hay mejor información empírica disponible. La FCC acumuló una cantidad impresionante de anécdotas que sugerían que la Doctrina de Equidad tenía un efecto neto de suprimir la expresión política. ${ }^{359} \mathrm{El}$ hecho de que la Doctrina de Equidad fuera promulgada en I949 (después de un largo período en el cual toda actividad editorial por los radioemisores estaba prohibida) y posteriormente prohibida en 1987 provee el fundamento de un experimento natural como también de su probable impacto. Si bien no hay disponibilidad de datos específicos sobre el cambio en 1949, hay consenso en que la imposición de la Doctrina de Equidad no condujo a un incremento en la expresión política. ${ }^{360}$ Existe mucha más información disponible respecto del efecto de su derogación en 1987. Estudios empíricos indican que la cantidad total de programación informativa transmitida por los radioemisores se ha disparado desde 1987 , principalmente a través de programas de radio (Hazlett y Sosa, I 997: 290-30I). Si bien muchos sueñan con la concepción idealizada de un discurso razonado asociado a las obras de la época de la fundación de Estados Unidos, como The Federalist y Common Sense, la expresión real de ese tiempo tiene un parentesco distintivo con la expresión política actual, pues ambas son caracterizadas por una defensa apasionada de posiciones no imparciales (cf. Yoo, 2003: 336-37, citando a Powe, Jr., I987: I83). A mayor abundamiento, es muy poco evidente que dicho disenso debiera ser lamentado o desalentado. Al contrario, el disenso es con frecuencia el signo de una sana sociedad pluralista (cf. Yoo, 2003: 32 I, citando a Gardbaum, I993: 385 ).

Quizás lo más problemático sea la facilidad con que los operadores

358. Red Lion v. FCC, pág. 367, 393; véase también FCC v. League, pag. 364, 378 (señalando que «si fuera a ser mostrada a la Comisión que la Doctrina de Equidad '[tiene] el efecto neto de la reducción en lugar de aumentar' la expresión, entonces estaríamos forzados a reconsiderar la base constitucional de nuestra decisión en [Red Lion]»).

359. I98 5 Fairness Report, I02 F.C.C.2d at I64-88 III 34-68.

360. Véase Fang y Whelan, Jr. (1973: 363-703); véase también: «A pesar de que la prohibición de Mayflower fue removida hace más de una década, editorializar por los licenciados de emisión (radiodifusión) de ninguna manera se ha convertido en una práctica frecuente» (Barron, I96I: I2). 
políticos pudieron usar la Doctrina de Equidad como una herramienta para silenciar a su oposición política. El caso Mayflower Broadcasting fue gatillado por la crítica a Franklin D. Roosevelt de la Yankee Network (Powe, I987: I09-Io). Y lo que es quizás más irónico, los analistas contemporáneos han estudiado que Red Lion v. FCC, la piedra basal de los esfuerzos para limitar la discreción editorial de los medios, fue el producto de una sistemática (y muy exitosa) campaña de las administraciones de los presidentes Kennedy y Johnson para desincentivar que los radioemisores transmitieran programación afín a su oposición (Friendly, I975: 33-42). Como lo admitió uno de los subsecretarios de comercio del presidente Kennedy: «Nuestra estrategia principal fue usar la Doctrina de Equidad para desafiar legalmente y acosar a los radioemisores de derecha con el fin de que los recursos fueran tan onerosos para ellos que se vieran inhibidos y decidieran que era demasiado caro continuar peleando» (Friendly, I975: 39). Esta conducta no fue exclusiva del Partido Demócrata. Richard Nixon utilizó tácticas similares como parte de su campaña en contra de lo que él caracterizaba como la prensa elitista de la Costa Este (Hazlett y Sosa, I998: 47-50). En resumen, como lo notó sabiamente el ministro Douglas, la Doctrina de Equidad «pone la cabeza del camello dentro de la carpa y permite, administración tras administración, manipular la televisión o la radio para servir sus sórdidos o benevolentes fines». ${ }^{361}$

Lo anterior enfatiza cómo la intervención gubernamental puede tener un efecto adverso en la libre expresión. Incluso si se adopta con fines benignos, la intervención puede deformar la expresión de formas inesperadas e indeseadas. ${ }^{362} \mathrm{Y}$ lo que es peor, todo sistema puede ser manipulado, y sus actores inevitablemente tienen incentivos para usar las reglas en su máximo provecho propio. Quizás lo más problemático sea la forma en que la regulación diseñada para atenuar el ejercicio extremo de la discreción editorial es vulnerable al abuso gubernamental. ${ }^{363}$ En efec-

36r. CBS v. DNC, (Douglas, J., concurriendo en la sentencia).

362. Yoo (2005: 675-713) analiza los efectos problemáticos que las regulaciones estructurales de la FCC podrían tener sobre el contenido de los medios.

363. Inquiry into Section 73.I910 of the Commission's Rules and Regulations Concerning the General Fairness Doctrine Obligations of Broadcast Licensees, Report, I02 F.C.C.2d I42, I92-94 IIII 74-76 (I985) (I985 Fairness Report); accord Brandywine- 
to, es probable que los intermediarios sean especialmente susceptibles a esta manipulación (Kreimer, 2006: 27-33). Si bien algunos analistas han expresado su confianza en que los tribunales poseen las herramientas doctrinarias para frenar dichos abusos (Kreimer, 2006: 46-79), yo soy menos optimista (Yoo, 2005: 713-25).

\section{CONCLUSIÓN}

En los últimos meses, los periódicos han estado colmados de quejas sobre como los proveedores de Internet discriminan a ciertos proveedores de contenidos o aplicaciones. Ya sea la política de Comcast en contra de programa de peer-to-peer BitTorrent, las decisiones de Google sobre como implementar su algoritmo de búsqueda, la decisión de Facebook de no permitir ciertos contenidos, o la negativa de Apple de incorporar los apps de voz en el iPhone, dichos actos han gatillado quejas de que los proveedores de Internet están dañando la libre expresión y por lo tanto su discreción debe restringirse.

Al desarrollar estos argumentos, estos defensores pasan por alto la longeva e importante tradición de libre expresión representada en la jurisprudencia sobre medios masivos de la Corte Suprema que reconoce cómo el ejercicio de discreción editorial por los intermediarios puede promover más que inhibir valores de libre expresión. Como mínimo, esta tradición propone una importante argumentación contrapuesta que debe ser considerada por cualquiera que apoya la desintermediación de contenidos en Internet. Un análisis honrado de estos casos sugiere que, dada la inaplicabilidad de los argumentos invocados para crear excepciones para otros medios electrónicos, la discreción editorial de estos intermediarios debe ser considerada inviolable.

Adicionalmente, todo intento de regular la forma en que estos intermediarios analizan y presentan contenidos en Internet probablemente afectará los mercados expresivos de formas que pueden ser muy problemáticas. Como he resaltado en mis otros trabajos, ningún protocolo de Internet está optimizado para cada aplicación; cada protocolo de

Main Line Radio, Inc. v. FCC, 473 F.2d I6, 78 n.62 (D.C. Cir. I972) (Bazelon, C.J., disidente) («El potencial de someter la teoría de la «equidad» al abuso político es inherente en el funcionamiento de la doctrina».). 
Internet inevitablemente favorece a algunas aplicaciones y perjudica a otras (Yoo, 2005: 25). En consecuencia no hay un principio basal para identificar un criterio sobre la intermediación que sea realmente neutral. En cambio, el regular la intermediación inevitablemente pone al gobierno en la posición de escoger ganadores y perdedores tecnológicos. La historia de los esfuerzos pasados para regular la discreción editorial de los intermediarios electrónicos no es reconfortante. No sólo quienes elaboran políticas fueron incapaces de desarrollar un criterio coherente para separar los ejercicios de discreción editorial permitidos de los no permitidos, sino que además el régimen regulatorio tuvo el efecto secundario de sesgar el debate y reducir la cantidad total de expresión.

Además, esta tradición nos recuerda una de las lecciones principales de la Primera Enmienda: que la intervención gubernamental es una amenaza mayor a la libre expresión que los actos de particulares. Ello no quiere decir que los actores privados no puedan afectar el ambiente expresivo, claramente pueden hacerlo. Pero nuestros principios de libre expresión están basados en la convicción de que «de estas dos opciones - censura pública o privada - la censura gubernamental puede ser la más penetrante, la más interesada, la más difícil de limitar y por lo tanto la que más debe evitarse. ${ }^{364}$ En resumen, al tener que elegir entre regulación gubernamental que, por una parte, garantiza que cada intermediario sea el todo para todos, y por la otra una que le permita al público poder elegir entre intermediarios que expresan su propia voz, los principios de libre expresión claramente estiman a este último como el menor de dos males.

Esta idea principal le da un nuevo significado al análisis de Lawrence Lessig de que «el código es ley» (I999: 6). Si bien algunos argumentan que el código representa una forma alternativa de gobernanza como justificación de regulación gubernamental, yo prefiero el punto de vista opuesto. El hecho de que el código afecte la libre expresión implica que deberíamos tener mucho cuidado antes de permitir que el gobierno regule el código. Si bien muchos académicos han promovido argumentos poderosos para transformar a la Primera Enmienda de una restricción negativa sobre el gobierno a una obligación afirmativa para el gobierno de promover una visión particular de la libre expresión, a la fecha esa visión no ha encontrado amplia aceptación.

364. CBS v. DNC, pág. I05. 
Pero incluso para aquellos que aceptan esta alternativa, una visión más afirmativa de la libre expresión no puede simplemente darle prioridad absoluta a los intereses de aquellos que desean expresarse a través de Internet. Ellos en cambio deben igualmente tomar en consideración los valores de libre expresión que promueven los intermediarios. Deberían a mayor abundamiento ser cuidadosos en no verse convencidos indebidamente por los argumentos de algunos de que las decisiones de un intermediario específico les han hecho más difícil expresarse. Cada ejercicio de discreción editorial inevitablemente favorece cierta expresión por sobre otra. En efecto, ese es todo el argumento, y limitaciones indebidas sobre la capacidad de los intermediarios para ejercer su discreción editorial les impediría efectuar sus propios y particulares aportes a la libre expresión.

\section{REFERENCIAS}

Abelson, Reed (2009). «F.C.C. Looking into Rejection of Google App for iPhone». New York Times, I de agosto, $\mathrm{B}_{5}$.

Armstrong, Mark (2006). "Competition in Two-Sided Markets». Rand Journal of Economics, 37: 668-69I.

Baker, C. Edwin (1976). "Commercial Speech: A Problem in the Theory of Freedom». Iowa Law Review, 62: I-56.

Balkin, Jack M. (I996). "Media Filters, the V-Chip, and the Foundations of Broadcast Regulation». Duke Law Journal, 45: I I 3 I-I I 75.

-. (2008). «Media Access: A Question of Design». George Washington Law Review, 76: Iо I-I 8 .

-. (2009). «The Future of Free Expression in a Digital Age». Pepperdine Law Review, 36: 427-444.

BARnouw, Erik (1966). A Tower in Babel. A History of Broadcasting in the United States. Nueva York: Oxford University Press.

Barron, Jerome A. (I96I). «The Federal Communications Commission's Fairness Doctrine: An Evaluation». George Washington Law Review, 30: I-4I.

-. (I967). "Access to the Press A New First Amendment Right». Harvard Law Review, 80: I64I-I678.

-. (I993). «The Telco, the Common Carrier Model and the First 
Amendment. The «Dial-a-Porn» Precedent». Rutgers Computer and Technology Law Journal, I9: 37I-404.

BAXTER, William F. (I983). «Bank Interchange of Transactional Paper:

Legal and Economic Perspectives». Journal of Law \& Economics, 26: $54 \mathrm{I}-588$.

Berman, Jerry y Daniel J. Weitzner (1995). "Abundance and User Control: Renewing the Democratic Heart of the First Amendment in the Age of Interactive Media». Yale Law Journal, I04: I6I9-I637.

Birnhack, Michael D. y Niva Elkin-Koren (2003). «The Invisible Handshake: The Reemergence of the State in the Digital Environment». Virginia Journal of Law \& Technology, 8: I-58.

Blumenthal, Marjory S. y David D. Clark (200I). «Rethinking the Design of the Internet: The End-to-End Arguments vs. the Brave New World». ACM Transactions on Internet Technology, I: 70-I09.

Bolt, Wilko y Alexander F. Tieman (2006). «Social Welfare and Cost Recovery in Two-Sided Markets». Review of Network Economics, 5 . Bracha, Oren y Frank PAsquale (2008). «Federal Search Commission? Access, Fairness, and Accountability in the Law of Search». Cornell Law Review, 93: I I 49-I2 Io.

Brenner, Daniel (I99I). "Telephone Company Entry into Video Services: A First Amendment Analysis». Notre Dame Law Review, 67: 95-I 50. Brown, Jennifer Gerarda y Ian Ayres (1994). «Economic Rationales for Mediation». Virginia Law Review, 80: 323-402.

Buchanan, James M. y Gordon Tullock (1962). The Calculus of Consent. Michigan: University of Michigan Press.

Caillaud, Bernard y Bruno Jullien (2003). "Chicken \& Egg: Competition Among Intermediation Service Providers». Rand Journal of Economics, 34: 309-328.

Calabresi, Guido y A. Douglas Melamed (1972). «Property Rules, Liability Rules, and Inalienability: One View of the Cathedral». Harvard Law Review, 85: Io89-I I 28.

Chandler, Jennifer A. (2007). «A Right to Reach an Audience: An Approach to Intermediary Bias on the Internet». Hofstra Law Review, 35: I095-II37.

Clark, David D. y Marjory S. Blumenthal (2007). «The End-to-End Argument and Application Design: The Role of Trust». Federal Communications Law Journal, 63:357-390. 
Cotter, Thomas F. (2006). «Some Observations on the Law and Economics of Intermediaries». Michigan State Law Review, 2006: 67-82. Cramton, Peter C. (I984). «Bargaining with Incomplete Information: An Infinite-Horizon Model with Two-Sided Uncertainty». Review of Economic Studies, 5 I: 579-593.

DE Sola Pool, Ithiel (1983). Technologies of Freedom. Nueva York: Belknap Press.

Elkin-Koren, Niva (200I). "Let the Crawlers Crawl: On Virtual Gatekeepers and the Right to Exclude Indexing». University of Dayton Law Review, 26: 179-209.

Evans, David S. (2003). "The Antitrust Economics of Multi-Sided Platform Markets». Yale Journal on Regulation, 20: 325-38I.

Evans, David S. y Richard SchmalenseE (2007). "The Industrial Organization of Markets with Two-Sided Platforms». Competition Policy International, 3: I 5 I-I79.

Fang, Irving E. y John W. Whelan, Jr. (I973). «Survey of Television Editorials and Ombudsman Segments». Journal of Broadcasting, I7: 363-37I.

Faratin, Peyman y otros (2008). «The Growing Complexity of Internet Interconnection». Communications \& Strategies, 72: 5 I-7 I.

Felten, Ed (2007). "Verizon Violates Net Neutrality with DNS Deviations», Freedom to Tinker, I 2 de noviembre. Disponible en <https:// freedom-to-tinker.com/blog/felten/verizon-violates-net-neutralitydns-deviations/>.

Fiss, Owen M. (I996). Liberalism divided. Boulder: Westview Press.

Fowler, Mark S. y Daniel L. Brenner (I982). "A Marketplace Approach to Broadcast Regulation». Texas Law Review, 60: 207-257.

Friendly, Fred W. (1975). The Good Guys, the Bad Guys, and the First Amendment: Free Speech vs. Fairness in Broadcasting. Nueva York: Random House.

Fudenburg, Drew y Jean Tirole (I99I). Game Theory. Cambridge: The MIT Press.

Gardbaum, Stephen A. (1993). "Broadcasting, Democracy, and the Market». Georgetown Law Journal, 82: 373-396.

Goldberg, Victor P. y Richard A. Epstein (2005). «Introductory Remarks: Some Reflections on Two-Sided Markets and Pricing». Columbia Business Law Review, 2005: 509-5I4. 
Goldman, Eric. «Search Engine Bias and the Demise of Search Engine Utopianism». Yale Journal of Law \& Technology, 8: I 88-200.

Goldsmith, Jack L. (1998). "Against Cyberanarchy». University of Chicago Law Review, 65: I I99-I250.

Goodman, Ellen P. (2007). «Media Policy and Free Speech: The First Amendment at War with Itself». Hofstra Law Review, 35: I2III 260 .

-. (2008). «No Time for Equal Time: A Comment on Professor Magarian's Substantive Media Regulation in Three Dimensions». George Washington Law Review, 76: 897-913.

Grimmelmann, James (2007). «Don’t Censor Search». Yale Law Journal, Pocket Part 48. Disponible en <http://yalelawjournal.org/the-yale-law-journal-pocket-part/intellectual-property/don \% E2 \% 80\%99tcensor-search/>.

-. (2009). "The Google Dilemma». New York Law School Law Review, 53: 939-950.

Hammond, Allen S. (I995). «Regulating the Multi-Media Chimera: Electronic Speech Rights in the United States». Rutgers Computer and Technology Law Journal, 21: I-87.

Hansell, Saul (2008). «F.C.C. Vote Sets Precedent on Unfettered Web Usage». New York Times, 2 de agosto, CI.

-. (2009). «Sprint Banks on WiMax to Win Back Market Share». New York Times, 28 de septiembre, BI.

Hazlett, Thomas W. y David W. Sosa (I997). «Was the Fairness Doctrine a "Chilling Effect»? Evidence from the Postderegulation Radio Market». Journal of Legal Studies, 26: 279-301.

-. (I998). "Chilling» the Internet? Lessons from FCC Regulation of Radio Broadcasting». Michigan Telecommunications and Technology Law Review, 4: 35-68.

Hermalin, Benjamin E. y Michael L. Katz (2007). «The Economics of Product-Line Restrictions with an Application to the Network Neutrality Debate». Information Economics and Policy, I9: 2 I 5-248.

Herman, Bill D. (2006). "Opening Bottlenecks: On Behalf of Mandated Network Neutrality». Federal Communications Law Journal, 59: IO7-I 59.

Huber, Peter W. y otros (I999). Federal Telecommunications Law. Nueva York: Aspen Law \& Business Publishers. 
Hughes, Justin (2009). «Copyright Enforcement on the Internet. In Three Acts». University of Hokkaido Workshop Working Paper, 62: 2-84.

Jullien, Bruno (2004). «Two-Sided Markets and Electronic Intermediaries». CESifo Working Paper, I345: I-39.

Katz, Michael L. y Carl Shapiro (I985). «Network Externalities, Competition, and Compatibility». American Economic Review, 75: 424440.

Krattenmaker, Thomas G. y Lucas A. Powe, Jr. (I994). Regulating Broadcast Programming. Washington: Aei Press.

Kreps, David M. (1990). A Course in Microeconomic Theory. Princeton: Princeton University Press.

Kreimer, Seth F. (2006). «Censorship by Proxy: The First Amendment, Internet Intermediaries, and the Problem of the Weakest Link». University of Pennsylvania Law Review, I 55: I I-IOI.

Kumar, Vishesh (2008). "Cable Prepares an Answer to FiOS». Wall Street Journal, I4 de febrero, $\mathrm{B}_{3}$.

Lastowka, Greg (2008). "Google’s Law». Brooklyn Law Review, 73: I327-I4IO.

Lemley, Mark A. y Lawrence Lessig (200I). «The End of End-To-End: Preserving the Architecture of the Internet in the Broadband Era». University of California Los Angeles Law Review, 48: 925.

Lessig, Lawrence (I998). "What Things Regulate Speech: CDA 2.0 vs. Filtering». Jurimetrics Journal, 38: 629-670.

-. (1999). Code and Other Laws of Cyberspace. Nueva York: Basic Books.

-. (200I). The Future of Ideas: The Fate of the Commons in a Connected World. Nueva York: Vintage.

-. (2006). Network Neutrality: Hearing Before the S. Comm. On Commerce, Science \& Transportation, Iogth Cong. Disponible en $<\mathrm{http}: / /$ commerce.senate.gov/pdf/lessig-020706.pdf>.

Lessig, Lawrence y Paul Resnick (I999). "Zoning Speech on the Internet: A Legal and Technical Model». Michigan Law Review, 38: 395-43I.

Lewyn, Michael E. (I995). "When Is Time brokerage a Transfer of Control? The FCC's Regulation of Local Marketing Agreements and the Need for Rulemaking». Fordham Intellectual Property, Media and Entertainment Law Journal, 6: I-57. 
Libecap, Gary D. (I989). Contracting for Property Rights. Cambridge: Cambridge University Press.

Markoff, John (2009). "A New Internet?». New York Times, I 5 de febrero, A9.

MaY, Randolph J. (2007). "Net Neutrality Mandates: Neutering the First Amendment in the Digital Age». I/S: A Journal of Law and Policy for the Information Society, 3: 197-2 IO.

Merges, Robert P. (1996). «Contracting into Liability Rules: Intellectual Property Rights and Collective Rights Organizations». California Law Review, 84: I293-I393.

Musacchio, John y otros (2009). "A Two-Sided Market Analysis of Provider Investment Incentive with an Application to the Net-Neutrality Issue». Review of Network Economics, 8: 22-39.

Myerson, Roger B. y Mark A. Satterthwaite (i983). «Efficient Mechanisms for Bilateral Trading». Journal of Economy Theory, 265$28 \mathrm{I}$.

Nachbar, Thomas B. (2000). «Paradox and Structure: Relying on Government Regulation to Preserve the Internet's Unregulated Character». Minnesota Law Review, 85: 2I 5-3 I 7.

NADEL, Mark S. (I987). "Editorial Freedom: Editors, Retailers, and Access to the Mass Media». Hastings Communications and Entertainment Law Journal, 9: 213-253.

Netanel, Neil Weinstock (2008). «New Media in Old Bottles? Barron's Contextual First Amendment and Copyright in the Digital Age». George Washington Law Review, 76: $952-985$.

Noam, Eli M. (1996). "Media Concentration in the United States: Industry Trends and Regulatory Responses». Disponible en <http:// www.vii.org/papers/medconc.htm>.

Nocera, Joe (2008). «Stuck in Google's Doghouse». New York Times, I 3 de septiembre, CI.

Nunziato, Dawn C. (2009). Virtual Freedom: Net Neutrality and Free Speech in the Internet Age. Stanford: Stanford Law Books.

Olson Jr., Mancur (1965). The Logic of Collective Action. Nueva York: Harvard University Press.

Orbison, Charley (I977). "'Fighting Bob’ Shuler: Early Radio Crusader». Journal of Broadcasting, 21: 459-472.

Ostrom, Elinor (I990). Governing the Commons: The Evolution of 
Institutions for Collective Action. Cambridge: Cambridge University Press.

Peha, Jon M. (2007). "The Benefits and Risks of Mandating Network Neutrality, and the Quest for a Balanced Policy». International Journal of Communication, I: 644-668.

Powe JR., Lucas A. (1987). «Scholarship and Markets». George Washington Law Review, 56: I72-I86.

-. (1987). American Broadcasting and the First Amendment. Los Ángeles: University California Press.

Redish, Martin H. y Kirk J. Kaludis (1999). "The Right Of Expressive Access in First Amendment Theory: Redistributive Values and the Democratic Dilemma». Northwestern University Law Review, 93: IO83-II34.

Renda, Andrea (2008). I Own the Pipes, You Call the Tune: The Net Neutrality Debate and Its (Ir)Relevance for Europe. Bruselas: Centre for European Policy Studies. Disponible en <http://www.ceps.be/ceps/ download/I 579>.

Rochet, Jean-Charles (2003). "The Theory of Interchange Fees: A Synthesis of Recent Contributions». Review of Network Economics, 2: 97-I 24 .

Rochet, Jean-Charles y Jean Tirole (2003). «Platform Competition in Two-Sided Markets». European Economic Association, I: 990-I029.

-. (2006). «Two-Sided Markets: A Progress Report». Rand Journal of Economics, 37: 645-657.

Rosen, Jeffrey (2008) «Google's Gatekeepers». New York Times Magazine, 30 de noviembre, 50 .

Roson, Roberto (2005). «Two-Sided Markets: A Tentative Survey». Review of Network Economics, 4: I42-160.

Ross, Susan Dente (1998). «First Amendment Trump?: The Uncertain Constitutionality of Structural Regulation Separating Telephone and Video». Federal Communications Law Journal, 50: 28I-308.

Rowan, Ford (1984). Broadcast Fairness. Londres: Longman.

Schejter, Amit M. y Moran Yemini (2007). "Justice, and Only Justice, You Shall Pursue': Network Neutrality, the First Amendment and John Rawls's Theory of Justice». Michigan Telecommunications and Technology Law Review, I4: I37-I74.

Sewell, Stephen F. (1995). "The Federal Communications Commission 
and Time brokerage: A Regulatory Change of Course». Journal of Communications Law and Policy, 3: 89-106.

Shelanski, Howard A. (I997). "The Bending Line Between Conventional 'Broadcast' and Wireless 'Carriage'». Columbia Law Review, 97: IO48-1080.

SIDAK, J. Gregory (2006). «A Consumer-Welfare Approach to Network Neutrality Regulation of the Internet». Journal of Competition Law \& Economics, 2: 349-474.

Simon, Herbert (I97I). «Designing Organizations for an Information. Rich World. Speech at the Johns Hopkins University and Brookings Institution Symposium». En Martin Greenberger (ed.), Computers, Communications, and the Public Interest. Nueva York: The Johns Hopkins University Press.

Solum, Lawrence B. y Minn Chung (2004). "The Layers Principle: Internet Architecture and the Law». Notre Dame Law Review, 79: 8I 5-948.

Spulber, Daniel F. (I996). "Market Microstructure and Intermediation». Journal of Economic Perspectives, I 35.

-. (1999). Market Microstructure: Intermediaries and the Theory of the Firm. Cambridge: Cambridge University Press.

-. (2006). "Firms and Networks in Two-Sided Markets». En Terrence Hendershott (ed.), Handbooks in Information Systems: Economics and Information. Londres: Emerald Group Publishing.

Spulber, Daniel F. y Christopher S. Yoo (2008). "Rethinking Broadband Internet Access». Harvard Journal of Law and Technology, 22: I-74.

Sullivan, Kathleen M. (I998). "First Amendment Intermediaries in the Age of Cyberspace». University of California Los Angeles Law Review, 45: I653-I68I.

Sunstein, Cass R. (1995). "The First Amendment in Cyberspace». Yale Law Journal, I04: I757-I 804.

Sunstein, Cass R. (1995). Democracy and the Problem of Free Speech. Nueva York: Free Press.

Talley, Eric L. (I994). «Contract Renegotiation, Mechanism Design, and the Liquidated Damages Rule. Note». Stanford Law Review, 46: II95-I 244 . 
Tirole, Jean (I988). The Theory of Industrial Organization. Cambridge: The MIT Press.

Travis, Hannibal (2007). «Of Blogs, eBooks, and Broadband: Access to Digital Media as a First Amendment Right». Hofstra Law Review, 35: IOI-I63.

Tribe, Laurence H. (I988). American Constitutional Law. St. Paul: West Group.

Tushnet, Rebecca (2008). «Power Without Responsibility: Intermediaries and the First Amendment». George Washington Law Review, 76 : IOI-I3I.

Volokн, Eugene (1995). «Cheap Speech and What It Will Do». Yale Law Journal, I04: I805-1850.

Wagner, R. Polk (1997). «Filters and the First Amendment». Minnesota Law Review, 83: 75 5-8I3.

Weinberg, Jonathan (I998). "Rating the Net». Hastings Communications and Entertainment Law Journal, 19: 453-482.

Williamson, Oliver E. (1975). Markets and Hierarchies: Analysis and Antitrust Implications. Nueva York: Free Press.

Wortham, Jenna (2009). «Even Google Is Blocked with Apps for iPhone». New York Times, 29 de julio, BI.

Wu, Felix (20I I). "Collateral Censorship and the Limits of Intermediary Immunity». Cardozo Legal Studies Research Paper, 354: 293-350.

Wu, Tim (I997). "Cyberspace Sovereignty? - The Internet and the International System». Harvard Journal of Law and Technology, Io: 647-666.

-. (2003). «Network Neutrality, Broadband Discrimination». Journal of Telecommunications and High Technology Law, 2: I4 I-I76.

Yemini, Moran (2008). "Mandated Network Neutrality and the First Amendment: Lessons from Turner and a New Approach». Virginia Journal of Law \& Technology, I3: I-37.

Yoo, Christopher S. (2002). «Vertical Integration and Media Regulation in the New Economy». Yale Journal on Regulation, I9: I7 I-300.

-. (2003). "The Rise and Demise of the Technology-Specific Approach to the First Amendment». Georgetown Law Journal, 91: 247-356.

-. (2004). «Would Mandating Broadband Network Neutrality Help or Hurt Competition?: A Comment on the End-to-End Debate». Journal of Telecommunications and High Technology Law, 3: 23-68. 
-. (2005). "Architectural Censorship and the FCC». Southern California Law Review, 78: 669-73 I.

- (2005). «Beyond Network Neutrality». Harvard Journal of Law and Technology, I9: I-77.

-. (2006). "Network Neutrality and the Economics of Congestion». Georgetown Law Journal, 94: I 847-I908.

-. (2008). «Network Neutrality, Consumers, and Innovation». University of Chicago Legal Forum, 2008: I79-262.

-. (2009). «Network Neutrality After Comcast: Toward a Case-by-Case Approach to Network Management». En Randolph J. May (ed.), New Directions in Communications Policy. Durham: Carolina Academic Press.

-. (20I0). «Innovations in the Internet's Architecture that Challenge the Status Quo». Journal of Telecommunications and High Technology Law, 8: 79-99.

ZitTrain, Jonathan (2003). «Internet Points of Control». Boston Collage Law Review, 44: 653-688.

-. (2008). The Future of The Internet (And How to Stop It). New Haven y Londres: Yale University Press.

Zuckman, Harvey L. y otros (I999). Modern Communications Law. St. Paul: West Group.

\section{SOBRE EL AUTOR}

Christopher S. Yoo es profesor de Derecho y Comunicación y Director Fundador del Centro de Tecnología, Innovación y Competencia de la Facultad de Derecho de la Universidad de Pennsylvania. El autor agradece a la Fundación Milton y Miriam Handler por su apoyo financiero, así como también a los participantes en las presentaciones ante la $37 .^{\circ}$ Conferencia de Investigación en Comunicación, Información y Políticas de Internet de TPRC; al Coloquio de Medios Interactivos de Penn patrocinado por la Iniciativa Wharton de Medios Interactivos; al Departamento de Asuntos Legales y Corporativos de Microsoft; y a la Escuela de Derecho de la Universidad Seton Hall; así como también a Eric Goldman, Seth Kreimer y Mark Nadel por sus comentarios sobre los primeros borradores de este artículo. Todos los errores son responsabilidad del autor. 
Este artículo fue publicado originalmente en George Washington Law Review, Vol. 78, 2010, con el título «Free Speech and the Myth of the Internet as an Unintermediated Experience», y ha sido traducido al castellano por Martín Mois Freiwirth y Sebastián Molina Necul, con autorización expresa de su autor. 
